\title{
ESTUDO COMPARATIVO DE DIFERENTES SISTEMAS DE INSTALAÇÕES PARA PRODUÇÃO DE LEITE TIPO B, COM ÊNFASE NOS ÍNDICES DE CONFORTO TÉRMICO E NA CARACTERIZAÇÃO ECONÔMICA
}

\section{Alexandre Porto de Araujo}

Dissertação de Mestrado apresentada à Comissão de Pós-Graduação da Faculdade de Zootecnia e Engenharia de Alimentos da USP em 13 de julho de 2001, como parte dos requisitos para a obtenção do Título de Mestre em Zootecnia, na área de Concentração em Qualidade e Produtividade Animal.

Orientador: Prof.Dr. Holmer Savastano Júnior 


\section{FICHA CATALOGRÁFICA}

\section{Araújo, Alexandre Porto de}

A658e Estudo comparativo de diferentes sistemas de instalações para produção de leite tipo $\mathrm{B}$, com ênfase nos índices de conforto térmico e na caracterização econômica / Alexandre Porto de Araújo - Pirassununga, 2001.

$69 \mathrm{p}$.

Dissertação (Mestrado) -- Faculdade de Zootecnia e Engenharia de Alimentos - Universidade de São Paulo, 2001.

Orientador: Prof. Dr. Holmer Savastano Junior.

1. LEITE, produção, custo 2. INSTALAÇÕES, conforto térmico 3. BOVINOCULTURA DE LEITE, entalpia I. Título. 


\section{DEDICATÓRIA}

À Veridiana, minha companheira eterna, verdadeira “...jóia de real valor...”, pelo seu amor, paciência e imensa sabedoria; e aos meus três filhos Alexandre Filho, Renata Bianca e Bruno Amon, verdadeiros Espíritos Nobres confiados a $\operatorname{mim}$.

Com todo o meu amor e profunda gratidão, por fazerem parte da minha vida. 
“...A Glória de Deus é a inteligência...” D\&C 93:36

"...Qualquer princípio de inteligência que alcançarmos nesta vida, surgirá conosco na ressurreição...” D\&C 130:18 


\section{Agradecimentos}

Ao Prof. Dr. Holmer Savastano Junior, pelo exemplo profissional, pelo grande incentivo, orientação e dedicação, durante o desenrolar desta pesquisa.

Ao meu pai, Wandrelino de Araujo e minha mãe, Maria Imaculada Porto de Araújo, por me iniciarem no caminho do saber e me possibilitarem contato com animais desde pequeno.

Ao meu avô, Luiz Nelson Porto e a sua esposa D. Nancy, pelo apoio e ajuda durante a Faculdade.

Ao Luiz Roberto Monteiro Porto, grande criador de Bovinos de Leite e Mangalarga Marchador, que primeiro confiou nos meus conhecimentos profissionais, e muito me ensinou sobre administração e postura profissional.

Ao meu irmão Luiz Nelson e sua esposa Cláudia, pelo apoio durante o Mestrado.

Aos meus irmãos Antonio Carlos, Maria Fernanda, Maria Valéria, Maria Paula e Marco Júlio, pelo incentivo durante o Mestrado.

A Patrícia Nanya Brizante, grande amiga minha e de minha esposa, pelo incentivo e ajuda à minha esposa, nas muitas vezes em que eu ficava ausente de casa.

A Bolsas Auracária, particularmente ao Pres. Pedro Brassanini, pela concessão da Bolsa de auxílio.

Ao Pres. Saraiva e irmã Inês pelo incentivo e apoio ao Mestrado, compreendendo a importância dele para mim.

A Prof ${ }^{a}$. Dra. Catarina Abdalla Gomide, pelo carinho com que fui recebido na minha volta à Faculdade e pela indicação do Prof. Holmer como meu orientador.

Aos meus professores durante o tempo de graduação que acreditaram neste ideal e que aqui continuam até hoje, Profs . Drs. Catarina Abdalla Gomide, Edison Schalch, Evaldo Antonio Lencioni Titto, Marcus Antonio Zanetti, Raul Franzolin Neto, Romualdo Shigueo Fukushima e Sérgio Ari Ribeiro.

Aos meus colegas de Faculdade, que resolveram compartilhar seus conhecimentos com os alunos do curso de Zootecnia, Profa. Dra. Célia R. Orlandelli Carrer Prof. Marcelo Machado De Luca O. Ribeiro e ao Prof. Dr. Rogério Lacaz Ruiz. 
A FZEA/USP pela oportunidade de realização do curso de Mestrado em Zootecnia.

Aos Prof. Dr. Evaldo Antonio Lencioni Titto e Sérgio Ari Ribeiro, pelas valiosas contribuições na banca de Qualificação.

Ao Prof. Dr. Vicente Borelli que implantou o curso de graduação em Zootecnia na USP.

Ao Dr. Pyrro Massella, pelo suporte jurídico na implantação do curso de Zootecnia na USP.

A todos os meus professores do curso de graduação em Zootecnia, pelos ensinamentos recebidos, que serviram de base para a minha vida profissional.

A SIN- Soluções Informatizadas para Negócios Ltda, particularmente ao Sr. Frederico, pela cessão do programa computacional, Custo Leite, que serviu de base para processamento das coletas de dados relativo à custo de produção do leite deste experimento.

A Gláucia, Érica e Estelinha, pela paciência e ajuda, durante este período de curso.

Aos funcionários da Biblioteca, pela paciência na busca de material bibliográfico, pelas normas técnicas ensinadas e pela ficha catalográfica elaborada.

Aos meus colegas de Mestrado, pelos momentos de companheirismo, amizade e trocas de experiências vividas no período.

A Luciane Silva Martello, pela ajuda nas referências bibliográficas e nas idéias de texto recebidas.

Ao Dr. Zito e ao sr. Veridiano, proprietários da Fazendas Santa Cruz e Santa Terezinha, respectivamente, pela cessão das propriedades para a realização do experimento.

A todos aqueles que direta ou indiretamente foram fundamentais para eu alcançar este grande passo na minha vida.

Ao principalmente ao meu Pai Celestial, por ter criado com tanta perfeição e utilidade os animais, e que nos possibilitou o convívio com eles. 


\section{ÍNDICE}

LISTA DE FIGURAS .................................................................................. iv

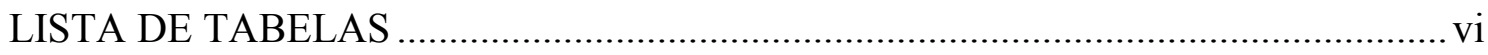

LISTA DE ABREVIATURAS E SÍMBOLOS......................................................... vii

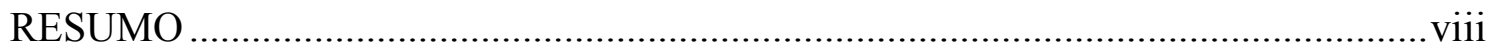

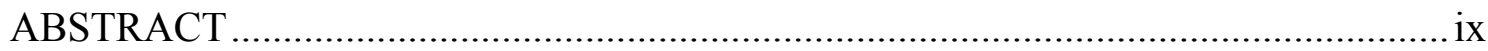

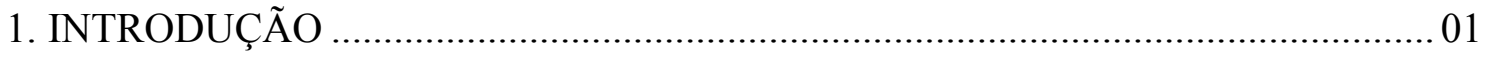

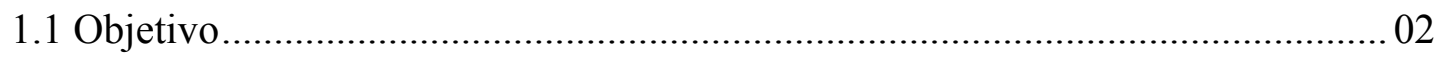

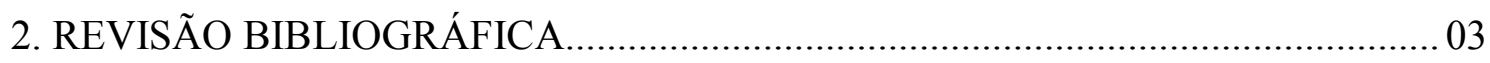

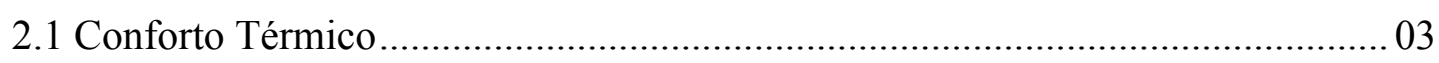

2.1.1. Zona de Conforto Térmico ...................................................................... 03

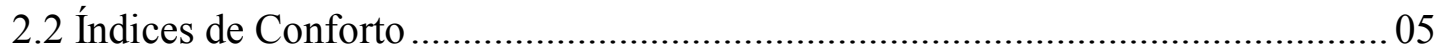

2.2.1 Índice de Temperatura Ambiente e Umidade (THI) ......................06

2.2.2 Índice de Temperatura de Globo e Umidade (ITGU).......................08

2.2.3 Índice de Temperatura Equivalente (ETI)..............................08

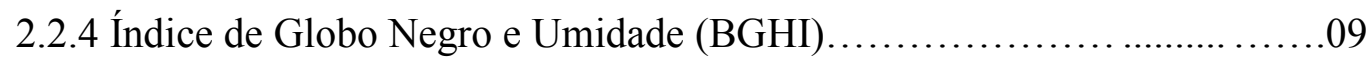

2.2.5 Carga Térmica de Radiação (CTR) ..................................... 10

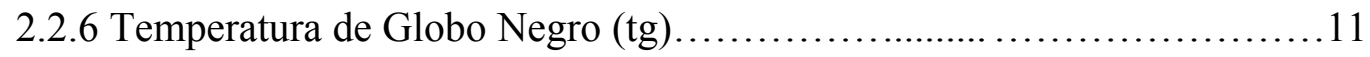

2.2.7 Temperatura Efetiva (TE)........................................11

2.3 Instalações e Conforto Térmico Animal ............................................................. 12

2.3 .1 Tie-stall ......................................................... 15

2.3.2 Free-stall.........................................................16

2.3.3 Pastejo Contínuo............................................... 17

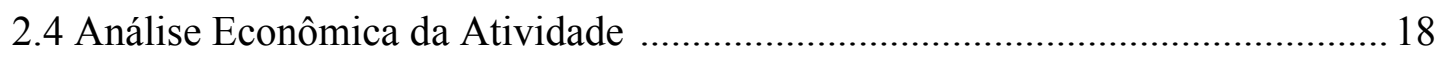

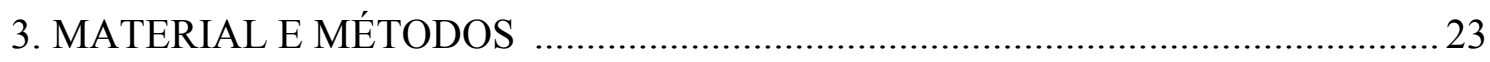

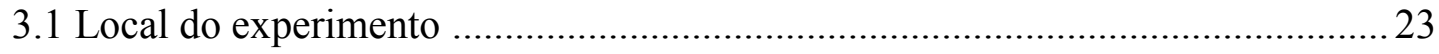




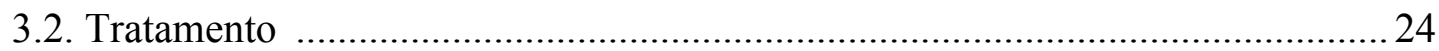

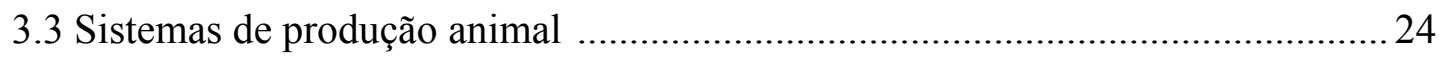

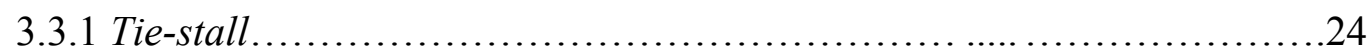

3.3.2 Free-stall.......................................................24

3.3.3 Pastejo contínuo.................................................25

3.4 Descrição das Instalações....................................................................................226

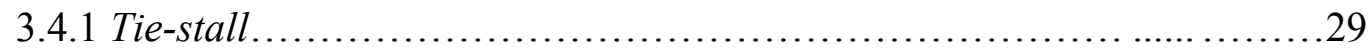

3.4 .2 Free-stall............................................................ 31

3.4.3 Pastejo contínuo.............................................. 33

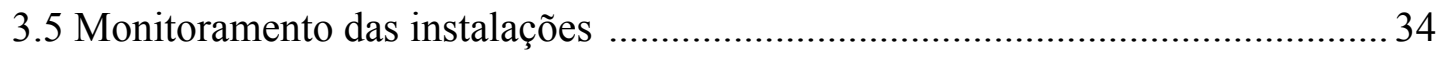

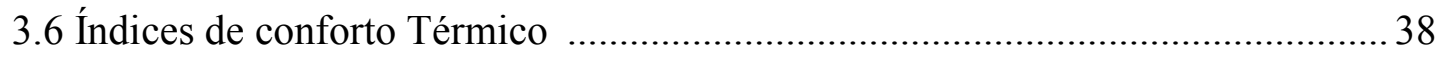

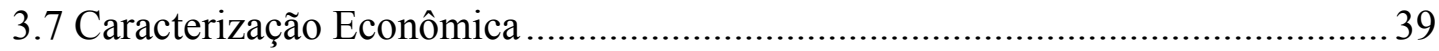

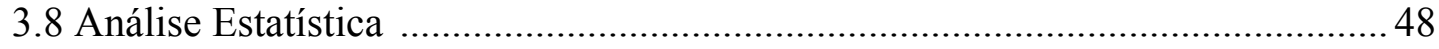

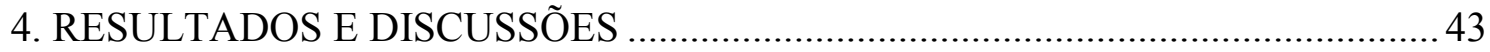

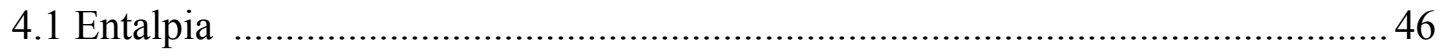

4.2 Índice de Temperatura do Globo Negro e Umidade (ITGU) ............................. 47

4.3 Índice de Globo Negro e Umidade (BGHI) ..................................................... 49

4.4 Índice de Temperatura Ambiente e Umidade(THI) .......................................... 51

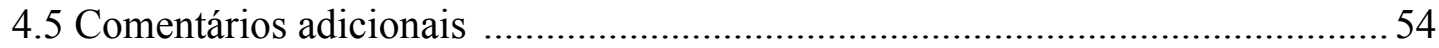

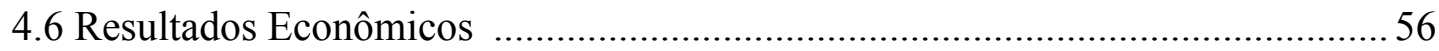

4.6.1 Caracterização econômica do tie-stall..............................57

4.6.2 Caracterização econômica do free-stall...............................58

4.6.3 Caracterização econômica do pastejo contínuo.........................59

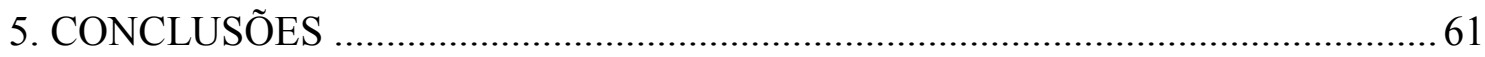

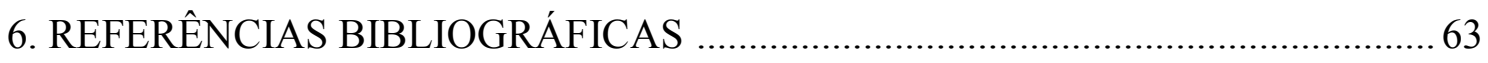

ANEXOS 


\section{LISTA DE FIGURAS}

FIGURA 2.1 - Zonas de tolerância e conforto térmico (TITTO, 1998) ......................... 04

FIGURA 2.2 - Trocas térmicas entre a vaca e o ambiente (TITTO, 1998) ................... 14

FIGURA 2.3 - Evolução do Índice de Preços ao Produtor (IPP-FGV) (Base $100=$

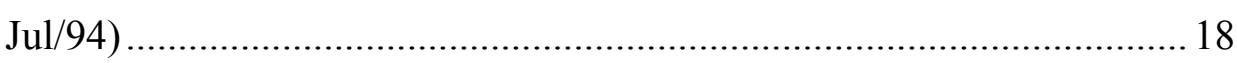

FIGURA 3.1- Vista frontal da instalação tie-stall ...................................................... 26

FIGURA 3.2 - Vista de perto mostrando detalhes do tie-stall ....................................2

FIGURA 3.3 - Vista mostrando instalação de free-stall e corredor de alimentação .....27

FIGURA 3.4 - Vista do free-stall, mostrando detalhes das baias individuais ..............28

FIGURA 3.5 - Vista em perspectiva mostrando o estábulo de alimentação para as

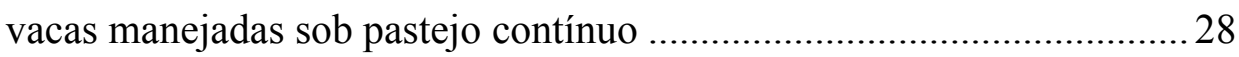

FIGURA 3.6 - Vista do interior do estábulo de alimentação .......................................29

FIGURA 3.7 - Esquema do tie-stall, com disposição das baias. Sem escala, medidas

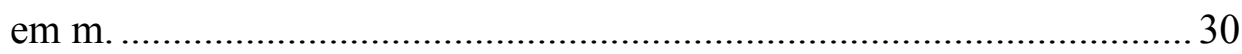

FIGURA 3.8 - Detalhe mostrando a inclinação do ventilador ........................................ 31

FIGURA 3.8a - Esquema do free-stall, com disposição das baias. Sem escala,

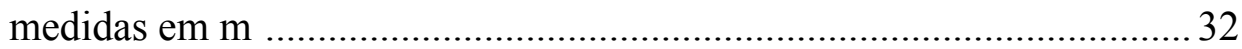

FIGURA 3.9 - Foto demonstrando detalhes de ventilador e nebulizador ...................... 33

FIGURA 3.10 - Esquema do estábulo para alimentação das vacas e com disposição

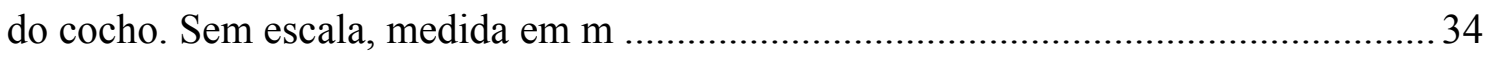

FIGURA 3.11 - Foto com detalhes dos instrumentos de monitoramento térmico no

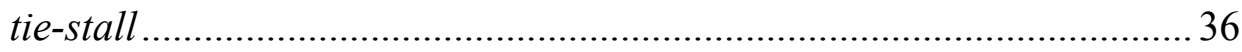

FIGURA 3.12 - Foto com detalhes dos instrumentos de monitoramento térmico no

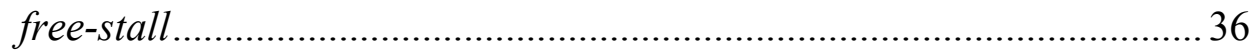


FIGURA 3.13 - Foto com detalhes dos instrumentos de monitoramento térmico no estábulo de alimentação para as vacas submetidas a pastejo contínuo.... 37

FIGURA 3.14 - Vista do abrigo meteorológico, do pluviômetro, do anemômetro e do termômetro de Globo Negro

FIGURA 3.15 - Interior do abrigo meteorológico, mostrando termômetro de máx. e mín. e higrômetro 38

FIGURA 4.1 - Variação da entalpia às 13 h nos diversos tipos de instalação, nos dias críticos

FIGURA 4.2 - Comparação dos valores de ITGU para os diversos tipos de instalação nos dias críticos 48

FIGURA 4.3 - Comparação dos valores de BGHI para os diversos tipos de instalação nos dias críticos 50

FIGURA 4.4 - Comparação dos valores de THI para os diversos tipos de instalação nos dias críticos 


\section{LISTA DE TABELAS}

TABELA 2.1 - Índice Temperatura - Umidade (THI) [Estresse ameno: 72-79;

Estresse moderado: 80-89; Estresse severo: 90-98] 07

TABELA 2.2 - Efeitos da temperatura do ar e da umidade na produção de leite 13

TABELA 2.3 - Vantagens e desvantagens do Sistema tie-stall .................................. 15

TABELA 2.4 - Vantagens e desvantagens do sistema free-stall ................................. 16

TABELA 2.5 - Vantagens e desvantagens do sistema de pastejo contínuo .................. 17

TABELA 2.6 - Preço do Leite no mundo ...................................................................... 20

TABELA 4.1 - Dias críticos em termos de entalpia ( $\mathrm{kJ} / \mathrm{kg}$ de ar seco), às $13 \mathrm{~h}$, na área externa aos sistemas produtivos (campo). Em itálico e negrito estão assinalados os maiores valores para o dia

TABELA 4.2 - Dias críticos em termos de entalpia ( $\mathrm{kJ} / \mathrm{kg}$ de ar seco), às $11 \mathrm{~h}$, na área externa aos sistemas produtivos (campo). Em itálico e negrito estão assinalados os maiores valores para o dia 45

TABELA 4.3 - Valores médios de entalpia (kJ/kg de ar seco) a campo às 11 e $13 \mathrm{~h}$ nos dias críticos 45

TABELA 4.4 - Valores de ITGU para os dias críticos nas diferentes instalações e a campo às $13 \mathrm{~h}$. Em itálico e negrito estão assinalados os maiores valores para o dia

TABELA 4.5 - Valores de BGHI nos dias críticos nas diferentes instalações e a campo às $13 \mathrm{~h}$. Em itálico e negrito estão assinalados os maiores valores para o dia.

TABELA 4.6 - Valores de THI nos dias críticos nas diferentes instalações e a campo às $13 \mathrm{~h}$. Em itálico e negrito estão assinalados os maiores valores para o dia 
TABELA 4.7 - Valores médios, para cada tipo de instalação, às 13 h, dos índices de conforto analisados

TABELA 4.8 - Valores médios, para cada tipo de instalação, às 11 h, dos índices de conforto analisados

TABELA 4.9 - Custos de produção de leite tipo "B" em cada sistema de produção comparados com o valor pago pela cooperativa local. Valores em reais $(\mathrm{R} \$)$.

TABELA 4.10 - Custos detalhados de produção de leite tipo "B" no sistema tiestall, em relação ao valor pago pela cooperativa local. Valores em reais $(\mathrm{R} \$)$

TABELA 4.11 - Custos detalhados de produção de leite tipo "B" no sistema freestall, em relação ao valor pago pela cooperativa local. Valores em reais $(\mathrm{R} \$)$

TABELA 3.4 - Custos detalhados de produção de leite tipo "B" no sistema de pastejo contínuo, em relação ao valor pago pela cooperativa local. Valores em reais $(\mathrm{R} \$)$ 


\section{LISTA DE ABREVIATURAS}

$\begin{array}{ll}\text { BGHI } & \text { Índice de Globo Negro e Umidade } \\ \text { COE } & \text { Custo Operacional Efetivo } \\ \text { COT } & \text { Custo Operacional Total } \\ \text { CT } & \text { Custo Total } \\ \text { CTR } & \text { Carga Térmica de Radiação } \\ \text { ETI } & \text { Índice de Temperatura Equivalente } \\ \text { FAO } & \text { Food Agriculture Organization } \\ \text { FGV } & \text { Fundação Getúlio Vargas } \\ \text { GN } & \text { Globo Negro } \\ \text { HSD } & \text { Honest Significant Difference } \\ \text { IEA } & \text { Instituto de Economia Agrícola } \\ \text { IPP } & \text { Índice de Preços ao Produtor } \\ \text { ITGU } & \text { Índice de Temperatura de Globo e Umidade } \\ \text { TE } & \text { Temperatura Efetiva } \\ \text { TGN } & \text { Termômetro de Globo Negro } \\ \text { THI } & \text { Índice de Temperatura Ambiente e Umidade } \\ \text { TMR } & \text { Temperatura Média Radiante } \\ \text { USDA } & \text { States Department of Agriculture } \\ \end{array}$




\section{RESUMO}

O objetivo deste trabalho foi realizar um estudo de caso comparando índices de conforto térmico de diferentes instalações, utilizadas por vacas em lactação da Raça Holandesa, situadas em 2 propriedades particulares no Vale do Paraíba, SP. As condições ambientais e de topografia de ambas as propriedades eram semelhantes, as quais estão localizadas proximamente uma da outra.

Os tratamentos experimentais foram (i) free-stall, (ii) tie-stall e (iii) estábulo (utilizado para suplementação alimentar), cujos ambientes internos foram comparados com as condições ambientais do campo. Realizou-se ainda a caracterização econômica das propriedades, com o intuito de se obterem os custos de produção para cada sistema estudado.

Os parâmetros ambientais registrados foram a temperatura ambiente, de globo negro e de máxima e mínima, umidade relativa do ar e velocidade do vento. $\mathrm{O}$ experimento foi realizado durante o verão de 2000. Para a seleção dos dias críticos (mais desconfortantes), considerou-se o valor da entalpia associada à temperatura de bulbo seco de $24^{\circ} \mathrm{C}$ e umidade relativa de $76 \%$.

Os índices de conforto térmico analisados foram a entalpia, índice de temperatura e umidade (THI), índice de globo negro e umidade (BGHI) e índice de temperatura de globo e umidade (ITGU).

Observou-se que os índices de conforto térmico não apresentaram diferenças significativas $(\mathrm{p}<0,05)$ entre o campo e estábulo. Os mesmos índices não se diferenciaram $(\mathrm{p}<0,05)$ nas instalações do free-stall e tie stall. Para a metodologia empregada neste estudo, o estábulo foi associado com índices de conforto térmico significativamente piores $(\mathrm{p}<0,05)$, comparados com os das outras duas instalações desse experimento.

Sob o aspecto econômico, o custo total do leite produzido em qualquer um dos sistemas, foi superior ao valor recebido da cooperativa local.

Palavras chaves: leite, instalações, bovinocultura de leite, entalpia, custo de produção. 


\begin{abstract}
The objective of the present work was to undertake a study of case comparing indexes of thermal comfort inside different installations for milking cows of Holstein Breed at two private properties in the region of Vale do Paraíba, São Paulo State, Brazil. The properties were close to each other and presented similar characteristics for topography and environmental conditions. The economical characterization of the properties aimed to identify the cost production for each system under consideration.

The experimental treatments were (i) free-stall housing, (ii) tie-stall housing and (iii) stable for feed supplementation in comparison with the open field conditions. The environmental parameters measured were dry bulb temperature, black globe temperature, maximum \& minimum temperature, relative humidity of the air and wind speed. The experimental period was realized during the summer of the year to 2000. The selection of the discomforting critical days considered the enthalpy associated with the dry bulb temperature of $24^{\circ} \mathrm{C}$ and relative humidity of $76 \%$. The evaluation of the thermal comfort included the following parameters: enthalpy, temperature-humidity index (THI), black-globe humidity index (BGHI) and globe temperature and humidity index (ITGU).

The thermal comfort indexes did not indicate a significant difference $(p<$ $0.05)$ between the field and the stable for feed supplementation. The same indexes did not differentiate $(p<0.05)$ the free-stall from the tie-stall housing. According to the methodology employed at this study, the stable was associated with thermal comfort indexes significantly worse $(p<0.05)$ than the ones related to the other installations.
\end{abstract}

Regarding economical aspects, the total cost of milk produced in all systems was higher than the amount received from the local cooperative.

Key words: milk, installations, dairy cattle, enthalpy, cost of production. 


\section{INTRODUÇÃO}

Produzir leite no Brasil é, hoje, mais do que nunca, um grande desafio ao produtor rural, visto a grande dificuldade de fazer um planejamento ao longo dos anos, em razão da falta de política agropecuária definida do governo e ao próprio cenário econômico-financeiro do país. Além dessas dificuldades, outra com que o produtor se depara é produzir leite nos trópicos, onde as condições climáticas não são muito favoráveis para as vacas de raça européia, que são as maiores produtoras; visando contornar esta dificuldade, os produtores utilizam instalações que têm como objetivo principal, minimizar ao máximo estas condições desfavoráveis.

A partir de 1994, com a implantação do Plano Real, que diminuiu sensivelmente, em decorrência da queda da inflação, os ganhos financeiros associados às atividades empresariais, tornou-se necessário o planejamento de investimentos, custos produtivos e capitais imobilizado.

Nota-se uma constante diminuição no número de produtores de leite, por meio da oferta de liquidação de plantéis, inclusive de produtores tradicionais, entre outras razões, por não terem condições de acompanhar o aumento do preço dos insumos, sempre em níveis maiores do que a inflação ou do que o aumento do preço do leite ao produtor (GOMES, 1998).

Faz-se também necessário na bovinocultura leiteira, a aplicação de conhecimentos técnicos relacionados a manejo, instalações, ambiência, conforto animal, tipo de alimentação e gerenciamento da mão-de-obra disponível.

As pesquisas demonstram que o desempenho animal (ganho de peso, eficiência alimentar e quantidade produzida de leite) é, em parte, relacionado ao seu sistema homeotermo (NÄÄS, 1989).

Os bovinos de leite têm necessidade de manterem a temperatura interna de seu corpo dentro de uma faixa ideal, para que possam sobreviver. Tal fato se dá por 
intermédio de alguns mecanismos orgânicos de controle, que lhes permitem manter um balanço térmico adequado entre o calor que seus corpos produzem e aquele que ganham ou perdem para o meio.

Como as vacas leiteiras em confinamento não têm a possibilidade de escolher um ambiente melhor em termos de conforto térmico, como ocasionalmente têm na natureza, torna-se necessário que as instalações sejam: confortáveis, práticas e funcionais.

Isso se consegue a partir da climatização das instalações, ou seja, o conjunto de medidas naturais e artificiais que proporcionam, ao animal alojado, as condições favoráveis para diminuir seu estresse e consequentemente aumentar sua capacidade produtiva.

\subsection{Objetivo}

O objetivo deste trabalho é o estudo de caso de três diferentes sistemas produtivos de leite tipo B (tie-stall, free-stall e pastejo contínuo), com destaque para o conforto térmico das instalações empregadas, na região de São José dos Campos, SP. Esse objetivo será realizado por meio da comparação das instalações entre si e em relação ao ambiente externo, com base nos índices de conforto, nos dias de entalpia elevada.

Outro objetivo é apresentar a caracterização econômica de cada um dos sistemas de produção estudados. 


\section{REVISÃO BIBLIOGRÁFICA}

No presente capítulo, são discutidos conceitos relacionados ao conforto térmico dos animais e à viabilidade da atividade leiteira. Os índices de conforto térmico são apresentados como uma forma simplificada e eficaz de avaliação do conforto, em diversos sistemas produtivos de leite. Tais sistemas são vistos com ênfase nas instalações utilizadas, responsáveis pela maior parte da radiação presente no ambiente de produção. O conforto e a produção resultante desses sistemas têm influência direta na viabilidade econômico-financeira da atividade, bem como na sobrevivência dos produtores, daí ser destinado um item específico para esse tópico na revisão.

\subsection{Conforto Térmico}

Conforto térmico traduz uma situação em que o balanço térmico é nulo, isto é, o calor que o organismo do animal produz, mais o que ele ganha do ambiente, é igual ao calor perdido por intermédio da radiação, da convecção, da condução, da evaporação e do calor contido nas substâncias corporais eliminadas (SILVA, 1998). Se isso não ocorre, o animal se defende por outros mecanismos de termorregulação, com o objetivo de ganhar ou perder calor para o ambiente em que está.

\subsubsection{Zona de Conforto Térmico}

Para NÄÄS (1989), zona de conforto ou de termoneutralidade, seria aquela limitada pela máxima e mínima temperatura ótima para a produção. Nesse intervalo de temperatura ambiente, ocorre o menor desgaste do animal, que se torna mais saudável e produtivo. Por não ocorrer estresse pelo frio ou pelo calor, a demanda fisiológica é mínima, e a temperatura corporal e o apetite são normais. Assim, a vaca 
produtora de leite terá um gasto mínimo de energia para manter sua temperatura corporal e a energia do organismo pode ser dirigida para a produção animal. (BACCARI, 1998a).

Existe alguma divergência na literatura, quanto à faixa ideal de temperatura para os bovinos de raça holandesa. Por exemplo, BAETA \& SOUZA (1997), relatam que a faixa ideal de temperatura estaria entre -1 e $16^{\circ} \mathrm{C}$, enquanto HUBER (1990) encontrou como intervalo de conforto térmico aquele compreendido entre 4 e $26^{\circ} \mathrm{C}$.

Essa diferença entre a zona de termoneutralidade apresentada por pesquisadores diferentes deve-se à capacidade de adaptação dos animais a situações climáticas específicas (NÄÄS, 1999); a condições fisiológicas, reprodutivas e nutricionais dos animais (TITTO, 1998), além da produtividade. Entretanto, todos concordam que existe uma faixa ideal de conforto térmico e que, acima ou abaixo desse intervalo, as vacas da raça holandesa passariam à condição de tolerância ao calor e ao frio, ocorrendo uma demanda fisiológica no sentido do organismo ter uma sobrecarga de trabalho com o intuito de manter a temperatura corpórea estável; um pouco mais além, limitado pelo "limite de tolerância ao frio"e pelo "limite de tolerância ao calor, o animal entra numa zona de estresse pelo calor ou pelo frio, onde se mantida as condições de temperatura por um período mais prolongado, o animal corre o risco de vir a morrer (Figura 2.1).

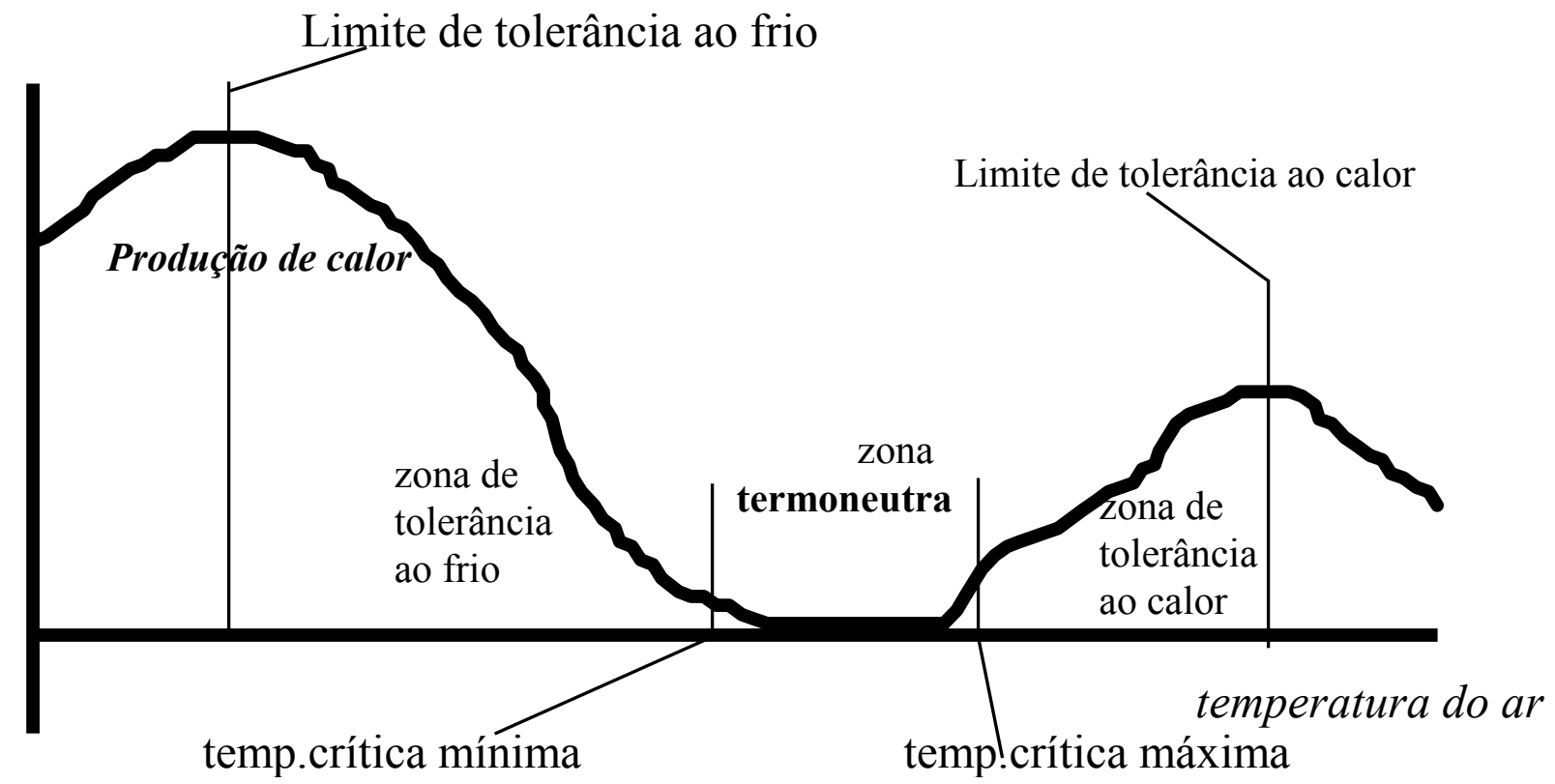

Figura 2.1. Zonas de tolerância e conforto térmicos (TITTO, 1998). 


\section{2 Índices de Conforto Térmico}

São índices que conseguem quantificar, em uma única variável, o efeito do estresse térmico sofrido pelos animais a partir das condições meteorológicas prevalecentes em um dado momento (MOURA \& NÄÄS, 1993).

Comparações de desempenho entre diferentes modelos de instalação, em razão do grande número de variáveis envolvidas, são facilitadas pelos índices de conforto térmico animal.

NÄÄS (1989) classificou os índices de conforto térmico em:

- Biofísicos, baseados nas trocas de calor entre o corpo e o ambiente.

- Fisiológicos, que se baseiam nas relações fisiológicas originadas por condições conhecidas de temperatura ambiente, temperatura radiante média, umidade relativa do ar e velocidade do ar.

- Subjetivos, que traduzem sensações subjetivas de conforto em face de variações dos elementos de conforto térmico.

Vários índices têm sido desenvolvidos com o objetivo de determinar níveis de conforto térmico, nas diferentes condições ambientais.

Inicialmente, utilizava-se a temperatura ambiente para determinar se o animal estava em situação de conforto ou não, e se estabeleciam então faixas de temperatura ideal para as diversas espécies ou raças. A partir de 1970 (BOND, 1971 e BUFFINGTON, 1977), outras variáveis foram incorporadas na avaliação de conforto térmico para os animais. Por intermédio do estudo mais criterioso da influência de outros fatores que, além da temperatura ambiente, influem no desempenho dos animais, chegou-se então aos vários índices utilizados atualmente.

Segundo MOURA \& NÄÄS (1993), os índices de conforto térmico têm grande importância para os produtores, já que podem, por um único valor, quantificar o estresse térmico a que o animal está submetido num dado momento e local, de acordo com as condições meteorológicas existentes.

Para a escolha de um ou outro índice, deve-se levar em conta as condições ambientais, a atividade desenvolvida pelo animal (totalmente estabulado, semiestabulado ou a pasto) e a maior ou menor importância de um ou outro aspecto do 
conforto. NÄÄS (1989) enfatiza que há condições termo-higrométricas que podem, mesmo que apenas temporariamente, serem consideradas como de conforto, em termos de sensação, e provocar distúrbios fisiológicos ao fim de algum tempo mais prolongado.

\subsection{1 Índice de Temperatura Ambiente e Umidade (THI).}

O índice THI, também chamado por alguns autores de ITU, foi proposto por THON (1958) e é um dos mais utilizados. Relaciona-se a temperatura e a umidade relativa do ar, sendo que os valores considerados limites, para situações de conforto ou estresse, não são coincidentes entre os diversos pesquisadores. Por exemplo, JOHNSON (1980) observou declínio na produção de leite a partir de THI igual a 72 (Tabela 2.1), por considerar que já é uma situação de stress para vacas holandesas. IGONO et al. (1992), entretanto, consideraram que THI acima de 76, em qualquer ambiente, é estressante para vacas com alta produção de leite. ROSENBERG et al. (1983), verificaram que THI entre 75 e 78 significa um alerta para o produtor, pois pode haver morte de animal; entre 79 e 84, é sinal de perigo, principalmente para rebanhos confinados; e, ao chegar ou ultrapassar o índice de 85 , é sinal de morte iminente, se não forem tomadas providências urgentes.

Este índice é obtido pela equação 2.1 a seguir.

$$
\mathrm{THI}=\mathrm{ta}+0,36 . \mathrm{tpo}+41,5
$$

Em que:

ta $=$ temperatura ambiente em ${ }^{0} \mathrm{C}$ (bulbo seco);

tpo $=$ temperatura de ponto de orvalho em ${ }^{0} \mathrm{C}$ 
Tabela 2.1-Índice Temperatura-Umidade (THI) [Estresse ameno: 72-79; Estresse moderado: 80-89; Estresse severo: 90-98].

\begin{tabular}{|c|c|c|c|c|c|c|c|c|c|c|c|c|c|c|c|c|c|c|c|}
\hline${ }^{0} \mathrm{C}$ & \multicolumn{19}{|c|}{ UMIDADE RELATIVA } \\
\hline & 10 & 15 & 20 & 25 & 30 & 35 & 40 & 45 & 50 & 55 & 60 & 65 & 70 & 75 & 80 & 85 & 90 & 95 & 100 \\
\hline 22,7 & & & & & & & & & & & & & & & & 72 & 72 & 73 & 73 \\
\hline 23,3 & $\mathrm{~S}$ & $\mathrm{E}$ & $\mathrm{M}$ & & $\mathrm{E}$ & $\mathrm{S}$ & $\mathrm{T}$ & $\mathrm{R}$ & $\mathrm{E}$ & $\mathrm{S}$ & $\mathrm{S}$ & $\mathrm{E}$ & & 72 & 72 & 73 & 73 & 74 & 74 \\
\hline 23,8 & & & & & & & & & & & & 72 & 72 & 73 & 73 & 74 & 74 & 75 & 75 \\
\hline 24,4 & & & & & & & & & & 72 & 72 & 73 & 73 & 74 & 74 & 75 & 75 & 76 & 76 \\
\hline 25,0 & & & & & & & & & 72 & 72 & 73 & 73 & 74 & 74 & 75 & 75 & 76 & 76 & 77 \\
\hline 25,5 & & & & & & & & 72 & 73 & 73 & 74 & 74 & 75 & 75 & 76 & 76 & 77 & 77 & 78 \\
\hline 26,1 & & & & & & & 72 & 73 & 73 & 74 & 74 & 75 & 76 & 76 & 77 & 77 & 78 & 78 & 79 \\
\hline 26,6 & & & & & 72 & 72 & 73 & 73 & 74 & 75 & 75 & 76 & 76 & 77 & 78 & 78 & 79 & 79 & 80 \\
\hline 27,2 & & & & 72 & 72 & 73 & 73 & 74 & 75 & 75 & 76 & 77 & 77 & 78 & 78 & 79 & 80 & 80 & 81 \\
\hline 27,7 & & & & 72 & 73 & 73 & 74 & 75 & 75 & 76 & 77 & 77 & 78 & 79 & 79 & 80 & 81 & 81 & 82 \\
\hline 28,3 & & & 72 & 73 & 73 & 74 & 75 & 75 & 76 & 77 & 78 & 78 & 79 & 80 & 80 & 81 & 82 & 82 & 83 \\
\hline 28,8 & & 72 & 73 & 73 & 74 & 75 & 75 & 76 & 77 & 78 & 78 & 79 & 80 & 80 & 81 & 82 & 83 & 83 & 84 \\
\hline 29,4 & 72 & 72 & 73 & 74 & 75 & 75 & 76 & 77 & 78 & 78 & 79 & 80 & 81 & 81 & 82 & 83 & 84 & 84 & 85 \\
\hline 30,0 & 72 & 73 & 74 & 74 & 75 & 76 & 77 & 78 & 78 & 79 & 80 & 81 & 81 & 82 & 83 & 84 & 84 & 85 & 86 \\
\hline 30,5 & 73 & 73 & 74 & 75 & 76 & 77 & 77 & 78 & 79 & 80 & 81 & 81 & 82 & 83 & 84 & 85 & 85 & 86 & 87 \\
\hline 31,1 & 73 & 74 & 75 & 76 & 76 & 77 & 78 & 79 & 80 & 81 & 81 & 82 & 83 & 84 & 85 & 86 & 86 & 87 & 88 \\
\hline 31,6 & 74 & 75 & 75 & 76 & 77 & 78 & 79 & 80 & 80 & 81 & 82 & 83 & 84 & 85 & 86 & 86 & 87 & 88 & 89 \\
\hline 32,2 & 74 & 75 & 76 & 77 & 78 & 79 & 79 & 80 & 81 & 82 & 83 & 84 & 85 & 86 & 86 & 87 & 88 & 89 & 90 \\
\hline 32,7 & 75 & 76 & 76 & 77 & 79 & 79 & 80 & 81 & 82 & 83 & 84 & 85 & 86 & 86 & 87 & 88 & 89 & 90 & 91 \\
\hline 33,3 & 75 & 76 & 77 & 78 & 79 & 80 & 81 & 82 & 83 & 84 & 85 & 85 & 86 & 87 & 88 & 89 & 90 & 91 & 92 \\
\hline 33,8 & 76 & 77 & 78 & 79 & 80 & 80 & 81 & 82 & 83 & 84 & 85 & 86 & 87 & 88 & 89 & 90 & 91 & 92 & 93 \\
\hline 34,4 & 76 & 77 & 78 & 79 & 80 & 81 & 82 & 83 & 84 & 85 & 86 & 87 & 88 & 89 & 90 & 91 & 92 & 93 & 94 \\
\hline 35,0 & 77 & 78 & 79 & 80 & 81 & 82 & 83 & 84 & 85 & 86 & 87 & 88 & 89 & 90 & 91 & 92 & 93 & 94 & 95 \\
\hline 35,5 & 77 & 78 & 79 & 80 & 81 & 82 & 83 & 85 & 86 & 87 & 88 & 89 & 90 & 91 & 92 & 93 & 94 & 95 & 96 \\
\hline 36,1 & 78 & 79 & 80 & 81 & 82 & 83 & 84 & 85 & 86 & 87 & 88 & 89 & 91 & 92 & 93 & 94 & 95 & 96 & 97 \\
\hline 36,6 & 78 & 79 & 80 & 82 & 83 & 84 & 85 & 86 & 87 & 88 & 89 & 90 & 91 & 93 & 94 & 95 & 96 & 97 & 98 \\
\hline 37,2 & 79 & 80 & 81 & 82 & 83 & 84 & 85 & 87 & 88 & 89 & 90 & 91 & 92 & 93 & 94 & 96 & 97 & 98 & 99 \\
\hline 37,7 & 79 & 80 & 82 & 83 & 84 & 85 & 86 & 87 & 88 & 90 & 91 & 92 & 93 & 94 & 95 & 97 & 98 & 99 & \\
\hline 38,3 & 80 & 81 & 82 & 83 & 84 & 86 & 87 & 88 & 89 & 90 & 92 & 93 & 84 & 95 & 96 & 97 & 99 & & \\
\hline 38,8 & 80 & 81 & 83 & 84 & 85 & 86 & 87 & 89 & 90 & 91 & 92 & 94 & 96 & 96 & 97 & 98 & & & \\
\hline 39,4 & 81 & 82 & 83 & 84 & 86 & 87 & 88 & 89 & 91 & 92 & 93 & 94 & 96 & 97 & 98 & & & & \\
\hline 40,0 & 81 & 82 & 84 & 85 & 86 & 88 & 89 & 90 & 91 & 93 & 94 & 95 & 96 & 98 & & & & & \\
\hline 40,5 & 82 & 83 & 84 & 86 & 87 & 88 & 89 & 91 & 92 & 93 & 95 & 96 & 97 & & & $\mathrm{~V}$ & & & \\
\hline 41,1 & 82 & 84 & 85 & 86 & 88 & 89 & 90 & 91 & 93 & 94 & 95 & 97 & 98 & & & $\mathrm{~A}$ & & & \\
\hline 41,6 & 83 & 84 & 85 & 87 & 88 & 89 & 91 & 92 & 94 & 95 & 96 & 98 & & & & $\mathrm{C}$ & & & \\
\hline 42,2 & 83 & 85 & 86 & 87 & 89 & 90 & 92 & 93 & 95 & 96 & 97 & & & & & $\mathrm{~A}$ & & & \\
\hline 42,7 & 84 & 85 & 87 & 88 & 89 & 91 & 92 & 94 & 95 & 96 & 98 & & & & & $\mathrm{~S}$ & & & \\
\hline 43,3 & 84 & 86 & 87 & 89 & 90 & 91 & 93 & 94 & 96 & 97 & & & & & & & & & \\
\hline 43,8 & 85 & 86 & 88 & 89 & 91 & 92 & 94 & 95 & 96 & 98 & & & & & & $\mathrm{M}$ & & & \\
\hline 44,4 & 85 & 87 & 88 & 90 & 91 & 93 & 94 & 96 & 97 & & & & & & & $\mathrm{O}$ & & & \\
\hline 45,0 & 86 & 87 & 89 & 90 & 92 & 93 & 95 & 96 & 98 & & & & & & & $\mathrm{R}$ & & & \\
\hline 45,5 & 86 & 88 & 89 & 91 & 92 & 94 & 96 & 97 & & & & & & & & $\mathrm{~T}$ & & & \\
\hline 46,1 & 87 & 88 & 90 & 91 & 93 & 95 & 96 & 98 & & & & & & & & $\mathrm{~A}$ & & & \\
\hline 46,6 & 87 & 89 & 91 & 92 & 94 & 95 & 97 & & & & & & & & & $\mathrm{~S}$ & & & \\
\hline 47,2 & 88 & 89 & 91 & 93 & 94 & 96 & 98 & & & & & & & & & & & & \\
\hline 47,7 & 88 & 90 & 92 & 93 & 95 & 97 & & & & & & & & & & & & & \\
\hline 48,3 & 89 & 90 & 92 & 94 & 96 & 97 & & & & & & & & & & & & & \\
\hline 48,8 & 89 & 91 & 93 & 94 & 96 & 98 & & & & & & & & & & & & & \\
\hline
\end{tabular}

Fonte: Desenvolvido por Dr. Frank Wiersma, Universidade do Arizona, citado por

PIRES et. al. (1998). 


\subsection{2 Índice de Temperatura de Globo e Umidade (ITGU)}

Esse índice considera, em sua formulação, a radiação solar, que é uma das mais importantes causas do estresse térmico para o homem e o animal. Determinado por MINARD et al. (1957), citado por CLARK (1981), o índice de temperatura de globo e umidade (ITGU ou WBGT) é baseado nas medidas da temperatura de globo negro, da temperatura do ponto de orvalho e da temperatura ambiente. $\mathrm{O}$ índice ITGU é dado pela fórmula 2.2 .

$\mathrm{ITGU}=0,7 . \mathrm{tbu}+0,2 . \operatorname{tg}+0,1 . \mathrm{ta}$

Para locais sombreados e bem ventilados, tem-se a equação 2.3 .

$$
\mathrm{ITGU}=0,7 . \mathrm{tbu}+0,3 . \mathrm{tg}
$$

Em que:

tbu $=$ temperatura de bulbo úmido $\left({ }^{\circ} \mathrm{C}\right)$;

$\operatorname{tg}=$ temperatura de globo negro $\left({ }^{\circ} \mathrm{C}\right)$;

ta $=$ temperatura ambiente $\left({ }^{\circ} \mathrm{C}\right)$.

\subsection{3 Índice de Temperatura Equivalente (ETI)}

Desenvolvido por BAETA et al. (1987), combina temperatura, umidade e velocidade do ar e se aplica para animais alojados. Baseado nesse índice, NÄÄS et al. (1991) desenvolveram um programa de computador denominado "Pró Leite", o qual, de maneira prática e eficiente, avalia instalações para gado leiteiro em regime totalmente estabulado, visando o conforto térmico, sob condições meteorológicas tropicais. É descrito pela equação matemática 2.4.

$$
\begin{gathered}
\text { ETI }=27,88-0,456 \cdot \mathrm{ta}+0,010754 .(\mathrm{ta})^{2}-0,4905 . \mathrm{h}+0,00088 .(\mathrm{h})^{2}+ \\
\text { 1,1507.v }-0,126447 .(\mathrm{v})^{2}+0,019876 . t . \mathrm{h}-0,046313 . t . v
\end{gathered}
$$


Em que:

ta $=$ temperatura do ar (bulbo seco), em ${ }^{\circ} \mathrm{C}$;

$\mathrm{h}=$ umidade relativa, em $\%$;

$\mathrm{v}=$ velocidade do vento, $\mathrm{em} \mathrm{m} / \mathrm{s}$.

No entanto, verificou-se que esse índice apresentava distorções ao ser utilizado pelo programa Pró Leite para animais em regime semi estabulado. Mais tarde, foi ajustado por LALONI (1996), resultando na equação 2.5.

$$
\mathrm{ETI}=29,83628-0,11519 . \mathrm{ta}+0,00059 . \mathrm{h}-0,30525 . \mathrm{v}
$$

Em que:

ta $=$ temperatura do ar (bulbo seco), em ${ }^{\circ} \mathrm{C}$;

$\mathrm{h}=$ umidade relativa do ar, em $\%$;

$\mathrm{v}=$ velocidade do vento, $\mathrm{em} \mathrm{m} / \mathrm{s}$.

\subsection{4 Índice de Globo Negro e Umidade (BGHI)}

O BGHI foi desenvolvido por BUFFINGTON et al. (1977) a partir das fórmulas do THI (ou ITU), substituindo a temperatura ambiente, ou de bulbo seco, pela temperatura de globo negro. É indicativo de conforto térmico para vacas leiteiras expostas a ambientes de radiação solar direta e indireta.

Nesse trabalho, os autores observaram correlação da produção de leite mais alta com o BGHI do que com o THI, sob radiação solar direta. À sombra, sob estresse moderado, os dois índices analisados apresentaram correlação similar com a produção de leite. Sob condições de estresse severo pelo calor, o BGHI foi portanto o índice que evidenciou mais o fato, sendo considerado um indicador mais preciso do conforto térmico animal. A equação 2.6 descreve o BGHI.

$$
\mathrm{BGHI}=\operatorname{tg}+0,36 . \operatorname{tpo}+41,5
$$


Em que:

$\operatorname{tg}=$ temperatura de globo negro $\left({ }^{\circ} \mathrm{C}\right)$;

tpo $=$ temperatura de ponto de orvalho $\left({ }^{\circ} \mathrm{C}\right)$.

\subsubsection{Carga Térmica de Radiação (CTR)}

A carga térmica de radiação (CTR) é a radiação total recebida por um corpo de todo o espaço circundante. Essa definição não engloba a troca líquida de radiação entre o corpo e o meio circundante, mas inclui a radiação incidente no corpo (BOND \& KELLY, 1955).

Ressalta-se que, em regiões de clima quente, a principal preocupação é a de proteger os animais da radiação solar direta, isto é, proporcionar-lhes a menor carga térmica radiante possível. Segundo COSTA (1982), a insolação direta (ou seja, a radiação solar) é a principal geradora do desconforto térmico nas edificações. CZARICK (1989), citado por GHELFI FILHO et al. (1991), observou que, em alguns casos, pequeno decréscimo na CTR poderia determinar substancial aumento na produção, a partir da melhora nas condições do ambiente interno das instalações.

A carga térmica de radiação (CTR), fornecida para cada tipo de instalação em W/m², proposta por ESMAY (1979), é dada pela equação 2.8.

$$
\mathrm{CTR}=\delta(\mathrm{TMR})^{4}
$$

Em que:

$\delta=5,67 \cdot 10^{-8} \mathrm{~W} /\left(\mathrm{m}^{2} \cdot \mathrm{K}^{4}\right)$ (constante de Stefan Boltzmann);

$\mathrm{TMR}=$ temperatura média radiante $(\mathrm{K})$.

$$
\mathrm{TMR}=100 .\left\{2,51 .(\mathrm{v})^{1,5} \cdot(\operatorname{tg}-\mathrm{ta})+(\operatorname{tg} / 100) 4\right\}^{1 / 4}
$$

Em que:

$\mathrm{v}=$ velocidade do vento $\mathrm{em} \mathrm{m} / \mathrm{s}$

$\operatorname{tg}=$ temp. globo negro

ta $=$ temperatura ambiente de bulbo seco ${ }^{\circ} \mathrm{C}$ 


\subsubsection{Temperatura de Globo Negro (tg).}

Segundo SEVEGNANI (1997), a temperatura de globo negro também é muito utilizada, isoladamente, como parâmetro para a avaliação das condições internas das instalações. Fornece, numa só medida, em graus Celsius $\left({ }^{\circ} \mathrm{C}\right)$, uma indicação dos efeitos combinados de temperatura do ar, temperatura radiante e velocidade do vento (BOND \& KELLY, 1955).

Para BEDFORD \& WARNER (1934), o termômetro de globo é uma maneira de se indicarem os efeitos combinados de radiação, convecção, e sua influência no organismo vivo, sendo, portanto, utilizado como um índice. Também segundo MARTA FILHO (1993), o globotermômetro permite inferir a CTR.

\subsubsection{Temperatura efetiva (TE)}

Segundo NÄÄS (1989), o índice de Temperatura Efetiva é definido como a temperatura de um ambiente sem movimentação significativa de ar, saturado de vapor de água, que reproduz a mesma sensação de conforto de calor para seres humanos. Este índice enfatiza e combina o efeito de perda ou ganho de calor por convecção e evaporação.

A fórmula utilizada neste trabalho substitui a temperatura de bulbo seco pela temperatura de globo negro, para efeito de cálculo. A temperatura de radiação, sendo superior ou inferior à temperatura de bulbo seco do ar, proporciona alterações na sensação de conforto.

$$
\mathrm{TE}=[22,3 . \operatorname{tg}+4,0829 .(\operatorname{tg}-\mathrm{tbu})] /[22,3+0,62817 .(\operatorname{tg}-\mathrm{tbu})]
$$

Em que:

$\operatorname{tg}=$ temperatura de globo negro $\left({ }^{\circ} \mathrm{C}\right)$;

tbu $=$ temperatura de bulbo úmido $\left({ }^{\circ} \mathrm{C}\right)$. 


\subsection{Instalações e Conforto Térmico Animal}

Em climas tropicais e subtropicais, os valores de temperatura e umidade relativa do ar têm-se mostrado restritivos ao desenvolvimento, à produção e à reprodução dos animais (OLIVEIRA et al., 1995). Seus organismos priorizam a manutenção da temperatura ideal (BACCARI, 1998b), visto que ocorre diminuição de ingestão de matéria seca e, conseqüentemente, de energia metabolizável.

Um dos objetivos de se confinarem vacas em lactação é se diminuir ou restringir ao máximo o efeito do ambiente sobre elas, em nossas condições tropicais não muito favoráveis, principalmente em razão da alta radiação solar (Figura 2.1). Os quatro fatores ambientais que mais atuam diretamente na temperatura efetiva são a temperatura de bulbo seco, a umidade relativa do ar, a radiação solar e a velocidade do vento (NÄÄS, 1998).

Outro fator limitante à produção leiteira, nos trópicos, é a alta temperatura associada à umidade elevada (BACCARI, 1998a, NÄÄS, 1998 e TITTO, 1998), pois se geram condições ambientais desfavoráveis ao bem estar da vaca holandesa produtora de leite, conforme Tabela 2.2; sendo que, além das variáveis climáticas, a fisiologia dos animais altera os limites de faixas térmicas, mas na maioria dos casos, para vacas de alta produção, a temperatura de $24{ }^{\circ} \mathrm{C}$ e $70 \%$ de UR inibe a produção (TITTO, 1998).

Muitas vezes, a fim de minimizar o efeito danoso da alta temperatura sobre a produção de vacas holandesas, os produtores usam ventiladores, associados opcionalmente a nebulizadores (ARCARO JÚNIOR, 2000), tendo em vista a melhoria das condições ambientais para a vaca em lactação, com a mínima alteração na ingestão de matéria seca (MACHADO, 1998), para que não haja conseqüente queda na produção de leite.

O uso de ventiladores com nebulizadores deve ser feito de maneira criteriosa pelos produtores, pois, usados erradamente, eles podem levar a um efeito adverso para as vacas. Ao contrário de conseguirem diminuição da temperatura ambiente pela ventilação forçada e resfriamento pela evaporação da água, podem fazer com que a umidade se eleve muito, o que acarreta estresse térmico maior nas vacas, queda na 
ingestão de matéria seca e, consequentemente, na produção de leite. Nessa situação indesejável, a água, ao invés de evaporar e causar um resfriamento do ambiente, cai sobre o animal ou sobre o piso do galpão e causa aumento considerável na umidade relativa do ar.

Tabela 2.2. Efeitos da temperatura do ar e da umidade na produção de leite*.

\begin{tabular}{||c|c|c|c|c||}
\hline \hline \multirow{2}{*}{$\begin{array}{c}\text { TEMPERA- } \\
\text { TURA ( }\end{array}$} & UMIDADE & \multicolumn{3}{|c||}{ RAÇA (\%) } \\
\cline { 3 - 5 } & RELATIVA (\%) & Holandesa & Jersey & Parda-Suiça \\
\cline { 3 - 5 } & 38 & 100 & 100 & 100 \\
\hline 24 & 76 & 96 & 99 & 99 \\
\hline 34 & 46 & 63 & 68 & 84 \\
\hline 34 & 80 & 41 & 56 & 71 \\
\hline
\end{tabular}

* Diferenças na produção de leite baseadas na porcentagem da produção normal de leite a $24^{\circ} \mathrm{C}$ e 38\% de umidade relativa (JOHNSON; VANJONACK, 1976 apud TITTO 1998).

Em sistemas produtivos para gado leiteiro, em regime semi ou totalmente estabulado, as instalações têm a função de abrigar os animais e criar um microclima com fatores climáticos amenizados. Assim, umidade relativa alta, associada a temperaturas elevadas, dificulta a dissipação de calor, quer seja por transpiração, ou por respiração do animal. Em geral, nos casos em que a umidade relativa ultrapassa os $50 \%$, pode já desencadear um início do desconforto animal em temperaturas mais elevadas. Já a temperatura, acima de $18,3^{\circ} \mathrm{C}$, independente da umidade ambiente, causa desconforto à vaca holandesa, que se acentua para a temperatura superior a $24^{\circ} \mathrm{C}$. Os ventos favorecem a evaporação, sem causar problemas patológicos, desde que entre 1,5 e $10 \mathrm{~m} / \mathrm{s}$ aproximadamente (LALONI, 1996).

TITTO (1998) propõe esquematicamente (Figura 2.2) uma série de possíveis formas diferentes de trocas térmicas entre o animal e o ambiente. Segundo MORGAN (1990), a radiação solar representa cerca de $75 \%$ da carga térmica transferida para o interior de um galpão. A cobertura é o sistema construtivo pelo qual se dá a principal entrada dessa carga térmica, daí o interesse em se estudar a 
interferência de materiais de cobertura, orientação da construção, projeção do telhado (beiral), insolação e vegetação circundante.

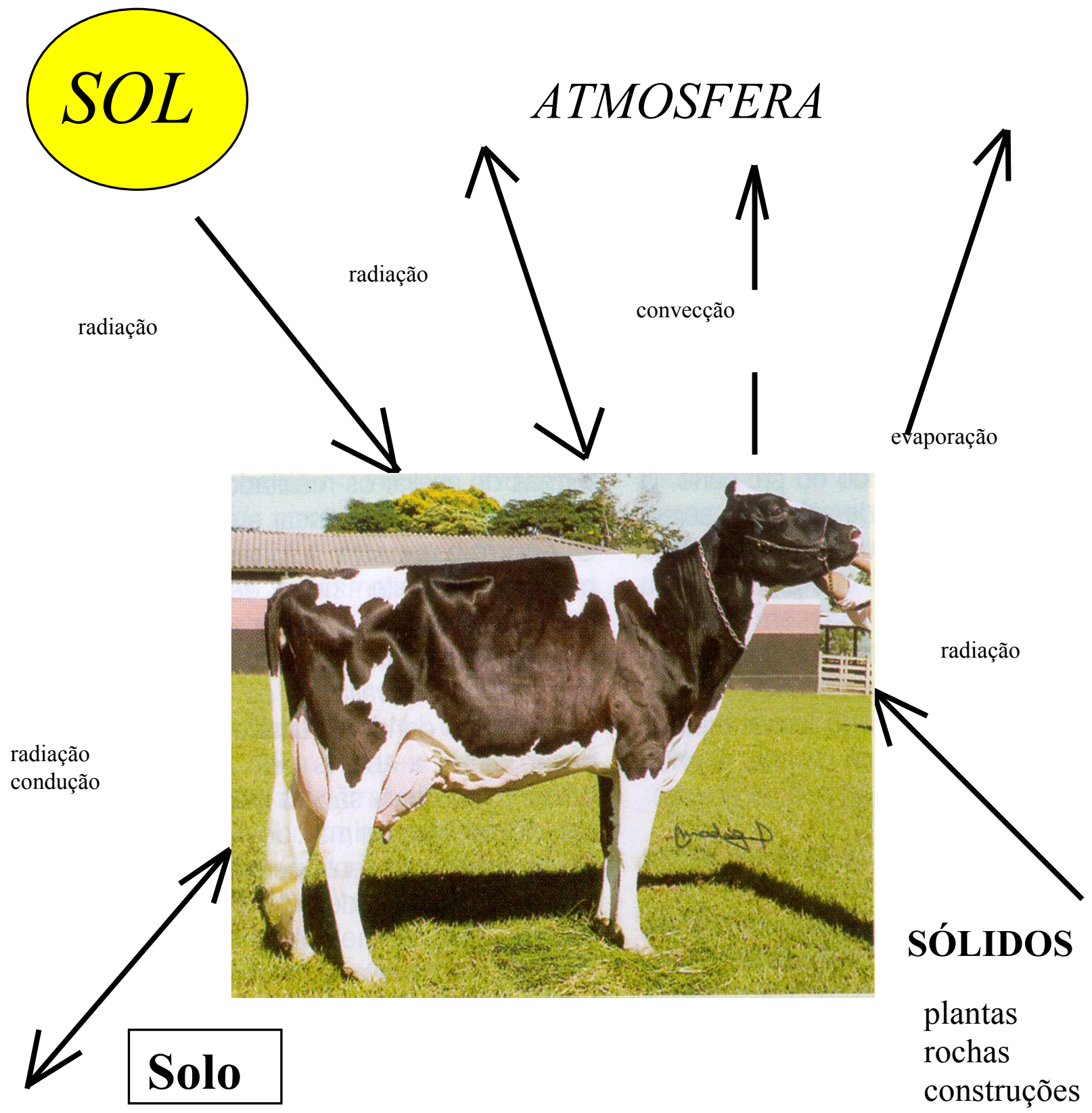

Figura 2.2. Trocas térmicas entre a vaca e o ambiente (TITTO, 1998).

Outra informação importante, obtida a partir da monitoração de temperatura e de umidade da instalação, é o cálculo da entalpia: variável física que indica a quantidade de energia (expressa em $\mathrm{kJ} / \mathrm{kg}$ de ar seco) contida em uma mistura de vapor d'água (SAVASTANO et al., 1997). 
Segue o detalhamento de três tipos de sistemas de produção, importantes para o presente trabalho, a saber: tie-stall, free-stall e pastejo contínuo.

\subsubsection{Tie-stall}

Sistema caracterizado por confinamento total das vacas durante o período produtivo, utilizado principalmente em rebanhos menores, devido ao seu alto custo de implantação (HUTCHINSON, 1999).

Elas ficam constantemente presas (dia e noite), geralmente por correntes no pescoço, e recebem $100 \%$ de sua alimentação no cocho, na forma de ração total. Assim, tudo o que elas necessitam para sua mantença e produção (volumoso alimentos com mais de 18\% de fibra bruta na matéria seca-, concentrado energético mais de $60 \%$ de nutrientes digestivos totais na matéria seca, e vitaminas, p. ex.), é administrado conjuntamente. Em geral, elas apenas ficam soltas por aproximadamente uma hora, a cada ordenha, quando aproveitam para fazer um pouco de exercício.

Normalmente são altíssimas produtoras de leite (acima de $25 \mathrm{~kg} / \mathrm{dia}$ ), pois, como é um sistema que exige mão-de-obra mais especializada e com investimento em infra-estrutura mais elevado, não se aplica a vacas de baixa lactação.

Tabela 2.3. Vantagens e desvantagens do sistema tie-stall

\begin{tabular}{||l|l||}
\hline \multicolumn{1}{|c|}{ VANTAGENS } & \multicolumn{1}{|c||}{ DESVANTAGENS } \\
\hline Vacas limpas & $\begin{array}{l}\text { Dificuldades em prender e soltar os } \\
\text { animais }\end{array}$ \\
\hline $\begin{array}{l}\text { Possibilidade de maior atenção a todos os } \\
\text { animais }\end{array}$ & $\begin{array}{l}\text { Reduz a oportunidade das vacas se } \\
\text { exercitarem }\end{array}$ \\
\hline Fácil mecanização & $\begin{array}{l}\text { Muito trabalho se não for manejo } \\
\text { mecanizado }\end{array}$ \\
\hline $\begin{array}{l}\text { Situação de trabalho do funcionário } \\
\text { confortável }\end{array}$ & Alto custo de construção das instalações \\
\hline $\begin{array}{l}\text { Prático manejo, principalmente para } \\
\text { rebanhos menores. }\end{array}$ & $\begin{array}{l}\text { Poucas possibilidades de separação de } \\
\text { vacas por lotes, maior possibilidade de } \\
\text { stress. }\end{array}$ \\
\hline
\end{tabular}




\subsubsection{Free-stall}

Surgiu nos Estados Unidos, na década de 50, e tornou-se muito popular no país rapidamente. Isso se deu pela sua superioridade, em termos de economia de cama e menos injúria em cascos e tetos das vacas, em relação ao sistema preponderante na época: "louse housing", ou seja, confinamento em estábulos com área de repouso coletivo. A expressão free-stall, ou estabulação livre, deve-se ao fato de as vacas ficarem soltas dentro de uma área cercada, sendo parte dela livre para alimentação e exercícios e a outra parte, dividida em baias individual e forrada com cama, é destinada ao descanso dos animais.

Tornou-se popular no Brasil a partir dos anos 80, quando alguns criadores particulares implantaram esse sistema com sucesso, e a Embrapa de Brasília construiu um confinamento tipo free-stall para mostrar a sua viabilidade aos produtores de leite (CAMARGO, 1991).

A alimentação das vacas é fornecida $100 \%$ no cocho, que pode ou não ser coberto, geralmente na forma de ração total, embora muitos criadores forneçam alguns itens da alimentação de forma separada.

É um sistema utilizado para vacas de médio a alto índice $(20-25 \mathrm{~kg} / \mathrm{dia}) \mathrm{de}$ produção individual (CAMARGO, 1991 e MATTOS, 1988). Como o custo de produção é alto, esse sistema não compensa para vacas com produção de leite abaixo de $20 \mathrm{~kg} / \mathrm{dia}$.

Tabela 2.4 Vantagens e desvantagens do Sistema free-stall

\begin{tabular}{||l|l||}
\hline \multicolumn{1}{|c|}{ VANTAGENS } & \multicolumn{1}{c||}{ DESVANTAGENS } \\
\hline Custo operacional econômico & Custo de construção alto \\
\hline Fácil mecanização & Menor atenção individual \\
\hline Animais se exercitam regularmente & Maior competição \\
\hline $\begin{array}{l}\text { Alta flexibilidade para organizar diferentes } \\
\text { manejos de alimentação, grupos etc. }\end{array}$ & $\begin{array}{l}\text { Vacas mais sujas por falha no manejo de } \\
\text { limpeza }\end{array}$ \\
\hline \hline
\end{tabular}




\subsubsection{Pastejo Contínuo}

Sistema tradicional em que as vacas são criadas o ano todo no pasto, indo ao curral apenas para ordenha, recebimento de alimentação concentrada e complementação da parte volumosa (geralmente capim picado, silagem de capim ou milho ou cana) no cocho. Os animais são mantidos geralmente em pastos nativos, com baixa produtividade e manejo precário, embora também existam propriedades com pastagens cultivadas.

Entre os inconvenientes para esse sistema, existe o fato de que, se o número de animais é pequeno, há sobra de forragem e formação de macega (capim seco e crescido dos pastos, que dificulta o trânsito) nas águas, quando a produção do pasto é boa, em razão da maior quantidade de chuvas, calor mais intenso e dias mais longos e claros nos trópicos Em contrapartida, na seca, o crescimento do capim é pequeno e o gado não recebe alimentação adequada para as suas necessidades fisiológicas de mantença e produção, devendo ser suplementado no cocho com alimentos mais nutritivos.

A alimentação é complementada no cocho com volumoso (alimentos com mais de $18 \%$ de fibra bruta na matéria seca) e concentrado (mais de $60 \%$ de nutrientes digestivos totais na matéria seca), este último geralmente dividido em duas partes (manhã e tarde) e oferecido durante a ordenha, no curral de espera ou na própria sala de ordenha.

Tabela 2.5 Vantagens e desvantagens do sistema de pastejo contínuo

\begin{tabular}{||l|l||}
\hline \multicolumn{1}{|c|}{ VANTAGENS } & \multicolumn{1}{c||}{ DESVANTAGENS } \\
\hline Custo Operacional mais baixo & Maior necessidade de área disponível \\
\hline Pouca necessidade de mecanização & Menor atenção individual \\
\hline Animais se exercitam regularmente & Maior competição entre os animais \\
\hline $\begin{array}{l}\text { Alguma flexibilidade em organizar os } \\
\text { animais em lotes }\end{array}$ & $\begin{array}{l}\text { Muitas vezes os lotes não são } \\
\text { homogêneos, por falta de espaço }\end{array}$ \\
\hline \hline
\end{tabular}




\subsection{Análise Econômica da Atividade}

A pecuária leiteira do Brasil é responsável por uma das maiores produções em volume de leite do mundo (sexto lugar, com vinte bilhões de litros de leite em 2000), apesar do baixo índice de 1343 litros/vaca/ano, segundo projeção do United States Department of Agriculture (USDA), citado pela Revista Balde Branco (1999a). Além disso, é um dos setores que mais precisou de profissionalização recentemente, pois, apesar do aumento do custo de mão-de-obra, insumos e equipamentos, o preço recebido pelo produtor sofreu considerável redução (NICOLAU, 1998, JANK, 1999) (Figura 2.3).

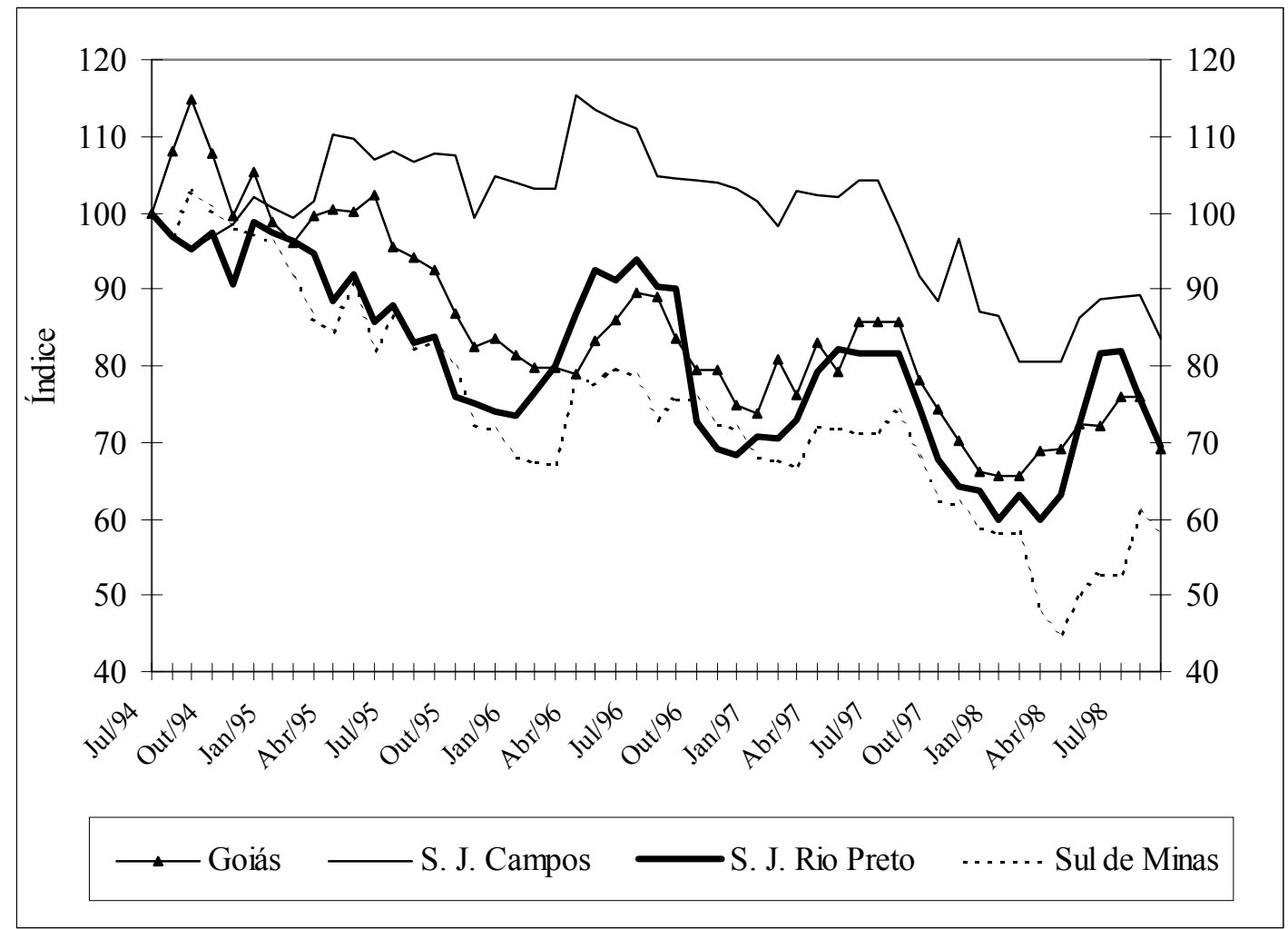

Fonte: JANK et al. (1999)

Figura 2.3. Evolução do Índice de Preços ao Produtor (IPP-FGV) (Base $100=$ Jul/94).

A redução de preço foi parcialmente interrompida em 2000, na época da entressafra, mas não por conquista direta dos produtores, e sim por pressão das 
indústrias processadoras de leite longa vida. $\mathrm{Na}$ ocasião, essas indústrias queriam conseguir uma correção do preço do leite junto aos supermercados, o que, em contrapartida, acarretou melhora no preço pago ao produtor. Conseguiu-se assim recuperação passageira do preço do leite, mas ainda sem alcançar o preço vigente em 1994. Tal correção foi passageira, pois a indústria abaixou, em seguida, o preço pago, estimulado pelo início das chuvas e excesso de leite no mercado, o que provocou nova queda de preço ao produtor.

Essa redução também se confirma pela análise dos preços em dólares norteamericanos. Na Tabela 2.3, observa-se que o preço pago ao produtor brasileiro é um dos menores do mundo. Isso tudo sem levarmos em conta os subsídios que os governos dos Estados Unidos e da União Européia dão a seus países. Os valores desses subsídios, apenas nos últimos 11 anos, aumentaram 400\% nos EUA, passando de US\$ 6,5 bilhões em 1990, para US\$ 32,3 bilhões em 2000. No início de maio de 2001 o Congresso dos Estados Unidos aprovou uma ajuda adicional à agricultura no valor de US\$ 79 bilhões, para os próximos 11 anos. Já na Europa, os subsídios custam US\$ 82,6 bilhões anuais, sendo que, em 1998 este subsídio equivalia a 37\% do valor bruto de produção (ROMERO, 2001).

Como conseqüência parcial disso, ocorreu diminuição considerável do número de produtores de leite nos últimos anos (GOMES, 1998). 
Tabela 2.6. Preço do leite no mundo.

\begin{tabular}{|c|c|}
\hline$\underline{\mathrm{PRECCO}}$ & PAÍSES \\
\hline$(\mathrm{US} \$ / \mathrm{KG})$ & \\
\hline $0.61-0.70$ & Japão \\
\hline $0.51-0.60$ & Suíça \\
\hline $0.46-0.50$ & El Salvador \\
\hline $0.41-0.45$ & Jordânia, Noruega. \\
\hline $0.36-0.40$ & Guatemala, Paquistão, Sudão. \\
\hline $0.31-0.35$ & $\begin{array}{l}\text { Alemanha, Áustria, Canadá, Colômbia, França, Grã-Bretanha, } \\
\text { Holanda, Irlanda, Israel, Panamá, Portugal, Venezuela. }\end{array}$ \\
\hline $0.26-0.30$ & $\begin{array}{l}\text { Bangladesh, Bósnia, COSTA Rica, Croácia, Estados Unidos, } \\
\text { Etiópia, Hungria, México, Nepal, Tanzânia, República Checa, } \\
\text { República Dominicana, Vietnã. }\end{array}$ \\
\hline $0.21-0.25$ & Botswana, Bulgária, China, Índia, Nigéria, Paraguai, Peru. \\
\hline $0.16-0.20$ & $\begin{array}{l}\text { África do Sul, Chile, Estônia, Latávia, Moldova, Polônia, Romênia, } \\
\text { Rússia, Uganda, Zimbabwe. }\end{array}$ \\
\hline $0.10-0.15$ & Argentina, Austrália, Brasil, Lituânia, Nova Zelândia, Uruguai. \\
\hline
\end{tabular}

Fonte: Dairy Outlook Network, FAO adaptado da Revista Balde Branco (1999b).

Atualmente, com a melhora de preço ao produtor, a situação melhorou um pouco, embora ainda esteja longe do ideal. Se, no período de julho a setembro de 2000, o preço do leite Tipo "B" pago ao produtor no estado em São Paulo, chegou perto de US\$ 0.20 em média, atualmente (maio de 2001), já está em US\$ 0.17 em média (base US\$ 1.00 comercial $=\mathrm{R} \$ 2,22$, para o dia 03/05/01), mas com perspectiva de em julho-setembro de 2001, chegar a R\$ 0,52 (cinqüenta e dois centavos de real), o que dará algo semelhante à US\$ 0.23 , demonstrando que o valor recebido pelo produtor é cíclico, sendo portanto, impossível de se fazer qualquer comparação em períodos isolados, além de mostrar que mesmo com alguma melhora de preço sazonal para o produtor, o leite produzido no Brasil, continua sendo remunerado pelo mercado, a valores dentre os mais baixos de nosso planeta. 
Devido a estas dificuldades, muito auxilia o produtor, conhecer o seu custo de produção que, do ponto de vista econômico, é a compensação que os produtores dos fatores de produção, utilizados por uma empresa para produzir determinado bem, necessitam receber para poderem continuar a fornecer esses fatores (HOFFMAN et al. 1981).Em outras palavras, o custo de produção, constitui o valor mínimo que o produtor precisa receber, para poder sobreviver na atividade produtiva desenvolvida.

É necessário então o planejamento da atividade leiteira, para que o produtor saiba quanto de leite ele tem que produzir e em quais situações, para que possa esperar o retorno econômico que possibilite sua sobrevivência.

Tal planejamento deve levar em conta todos os fatores que irão ou poderão influenciar, direta ou indiretamente, a atividade. Entre todos estes fatores, destacamse: terreno (topografia, tipo de solo e recursos hídricos), clima (temperatura, umidade e precipitação pluviométrica), recursos necessários (custo de financiamento, fontes disponíveis e prazo de retorno do investimento global) e etapas de implantação (NORONHA, 1988).

No planejamento, é necessário o conhecimento, pelo administrador, dos fatores que afetam os resultados econômicos, que são de natureza interna e externa (NGUYEN, 1990).

Fatores Externos. O administrador não tem controle sobre os fatores externos, mas tem que conhecê-los, para tomar as decisões que lhe permitam ajustar-se a eles. Assim, pode-se aproveitar ao máximo as condições favoráveis: preços dos produtos (histórico e tendência), clima (histórico e tendência), existência de mercado para os produtos, política de crédito e financiamento, transporte e disponibilidade de mão-deobra na região.

$\underline{\text { Fatores Internos. }}$ O administrador tem controle direto e, portanto, é necessário conhecê-los para poder tirar o maior proveito. São eles: tamanho da empresa agropecuária, rendimento dos cultivos e criações, seleção e combinação de atividades produtivas, eficiência da mão-de-obra, eficiência dos equipamentos e condições pessoais do administrador. 
Na produção de leite, mais do que nunca, o produtor é dependente dos fatores externos, principalmente no tocante a preço do produto, pois não tem nenhuma influência sobre ele, e pode apenas atuar no custo de produção.

Em se tratando de sistema de produção de leite, seu desempenho deve ser quantificado por meio do registro de índices físicos, econômicos e zootécnicos, para se determinarem os custos e receitas, o que possibilita o melhor planejamento da atividade (GOMES et al. 1985).

É necessária também a análise financeira da atividade, para se observar a lucratividade, a liquidez e o retorno sobre o capital. Muitas vezes, o custo de produção pode ser baixo, mas dar muito pouco retorno sobre o capital investido na atividade, ou vice-versa (JANK, 1997; JANK, 1998; MATTOS, 1997 e GITMAN, 1997).

Após análise da atividade que pretende iniciar e/ou continuar, o proprietário pode então definir qual o sistema de produção que adotará na propriedade, qual o retorno esperado, bem como sua adequação à mão-de-obra local, às condições meteorológicas da região e às condições geográficas. 


\section{MATERIAL E MÉTODOS}

\subsection{Local do experimento}

Este trabalho foi realizado na cidade de São José dos Campos, estado de São Paulo, localizado a $22^{\circ} 49^{\prime}$ de Latitude Sul e $45^{\circ} 54^{\prime}$ de Longitude Oeste, a uma altura média de $660 \mathrm{~m}$ do nível do mar e na cidade de Caçapava (localizada a uma altura média de 560 m acima do nível do mar), que é vizinha a São José dos Campos. O clima das duas cidades é do tipo CWA segundo a classificação de Köppen, tropical, sazonal, com duas estações bem definidas, verão chuvoso (outubro a março) e inverno seco (abril a setembro). O período de realização foi de 17 de janeiro a 31 de março de 2000.

Três instalações foram utilizadas, como objeto deste estudo de caso, com o intuito de se fazer uma análise comparativa entre elas, para avaliação do conforto térmico e de sua compatibilidade com o potencial genético dos animais, em termos de produção leiteira.

As três instalações foram escolhidas o mais próximo possível umas das outras, e que tivessem ambientes semelhantes em termos de clima e topografia para que o resultado não sofresse distorções pelo ambiente em que elas estavam localizadas.

Isso se conseguiu ao escolher duas das instalações (tie-stall e free-stall), localizadas na mesma propriedade (em São José dos Campos, SP) em construções contíguos uma à outra; a terceira delas estava localizada em uma propriedade distante apenas aproximadamente $6 \mathrm{~km}$ das demais (na cidade de Caçapava, SP), mas em condições geográficas bem semelhantes. 


\subsection{Tratamento}

Em cada uma das construções foram instalados os instrumentos para obtenção dos dados climáticos (temperatura do ar, umidade relativa do ar, temperatura de globo negro e velocidade do ar) que serviriam de base para a análise subseqüente.

Em todas as instalações monitoradas, e para o ambiente externo também, calculou-se, por meio de um programa computacional "psicart", desenvolvido por BIAGI \& SILVA em 1990, a entalpia do ambiente. Quanto maior o valor da entalpia, maior o calor existente no ambiente e mais desconfortante para o animal.

O conforto térmico para as vacas holandesas pode ser avaliado por meio de um valor limite da entalpia. Esse valor foi determinado como sendo o índice de $78,276 \mathrm{~kJ} / \mathrm{kg}$ de ar, calculado pelo aplicativo descrito acima, a partir da temperatura de $24^{\circ} \mathrm{C}$ e da umidade relativa do ar de $76 \%$ Esses limites foram indicados por JOHNSON \& VANJONACK (1976), citados por BACCARI 1998b, como os valores em que começa a se acentuar o estresse para as vacas holandesas.

\subsection{Sistemas de Produção Animal}

\subsubsection{Tie-stall}

Foi utilizada uma propriedade com 36 vacas em lactação e média de leite de $28 \mathrm{~kg} /$ dia. As vacas eram todas da raça Holandesa, variedade Preta e Branca, Pura de Origem, de primeira a terceira cria em sua maioria. Elas receberam ração total, no cocho, constituída de silagem de milho, feno de alfafa e concentrado, sempre à disposição dos animais e repostas quatro vezes ao dia. As vacas ficam permanentemente confinadas, com bebedouro para duas vacas, saindo três vezes ao dia para serem ordenhadas através de ordenhadeira mecânica, em sistema espinha de peixe.

\subsubsection{Free-stall}

A fazenda analisada tem um free-stall dividido em quatro partes (por um corredor central no sentido longitudinal para alimentação e um outro no sentido 
perpendicular para trânsito dos animais para a sala de ordenha) cada uma delas com 20 baias individuais, com cama de areia.

As vacas em lactação ficam constantemente confinadas, saindo apenas no horário das ordenhas, realizadas através de ordenhadeira mecânica, duas vezes ao dia. A alimentação é fornecida no corredor central, sempre à disposição dos animais, constituída de ração total, formada de silagem de sorgo e/ou milho, feno de capim coast-cross e ração balanceada, reposta três vezes ao dia.

As vacas são todas da raça Holandesa, variedade Preta e Branca, Puras de Origem, entre a primeira e a terceira lactação em sua maioria. Dos quatro boxes que constituem o free-stall, apenas três são usados atualmente, totalizando em média 80 vacas em lactação; as vacas são selecionadas para um ou outro boxe de acordo com a sua média de produção diária, fazendo com que cada lote seja o mais homogêneo possível em termos de produção. A média de produção de leite de todo o rebanho é por volta de $22 \mathrm{~kg} / \mathrm{dia}$.

\subsubsection{Pastejo Contínuo}

Lote constituído de aproximadamente 66 vacas da raça Holandesa variedade Preta e Branca, entre a primeira e a sexta lactação, com média de produção de leite de 18 a 22 1/vaca/dia. Os animais são, em sua maioria, Puros de Origem, mas existem aproximadamente $10 \%$ que são Puros por Cruzamento.

As vacas submetidas a este manejo ficam constantemente soltas em pastos com inclinação entre 7 e 10\%, formados de capim elefante ou braquiária, dia e noite, sendo presas apenas duas horas antes de cada uma das duas ordenhas diárias, realizadas no próprio curral de alimentação através de ordenhadeira mecânica, pelo sistema de balde ao pé, onde recebem suplementação alimentar de silagem de milho ou sorgo à vontade, conforme disponibilidade, e concentrado protéico, conforme produção de leite da vaca, sendo geralmente $1 \mathrm{~kg}$ de ração para cada 31 de leite produzido. A trocas dos piquetes é efetuada de forma empírica, conforme o capim começa a ficar mais baixo.

As ordenhas são realizadas às $5 \mathrm{~h}$ e às $15 \mathrm{~h}$ e as vacas são presas, no curral, com aproximadamente duas horas de antecedência, ficando mais uma hora depois de 
ordenhadas, amarradas também. No intervalo entre as ordenhas, os cochos são preparados com o volumoso, de tal maneira que, ao chegarem ao local, os animais já encontram o alimento disponível para consumo, que consomem em sua totalidade no período que ficam amarradas, havendo uma sobra apenas de 5\% todo total disponível no cocho (excedente este monitorado evitando que aja maior desperdício, ou falta do volumoso suplementado no cocho).

Os pastos têm água por meio de tanques naturais, que represam a água da chuva. As vacas fazem um revezamento conforme o pasto vai ficando mais baixo, sem existir um número de dias predeterminado. Quanto ao sombreamento, ele é constituído de árvores nativas, sem uma preocupação determinada de aliviar a insolação solar sobre as vacas. A área dos pastos sombreada é de aproximadamente $3 \%$ e composta de árvores nativas, quando o recomendável é por volta de $10 \% \mathrm{e}$ constituído de árvores específicas para este fim.

\subsection{Descrição das Instalações}

As Figuras 3.1 a 3.6 mostram as instalações das propriedades analisadas, sendo as Figuras 3.1 e 3.2 do tie-stall, as Figuras 3.3 e 3.4 do free-stall, e as Figuras 3.5 e 3.6, do regime de pastejo contínuo.

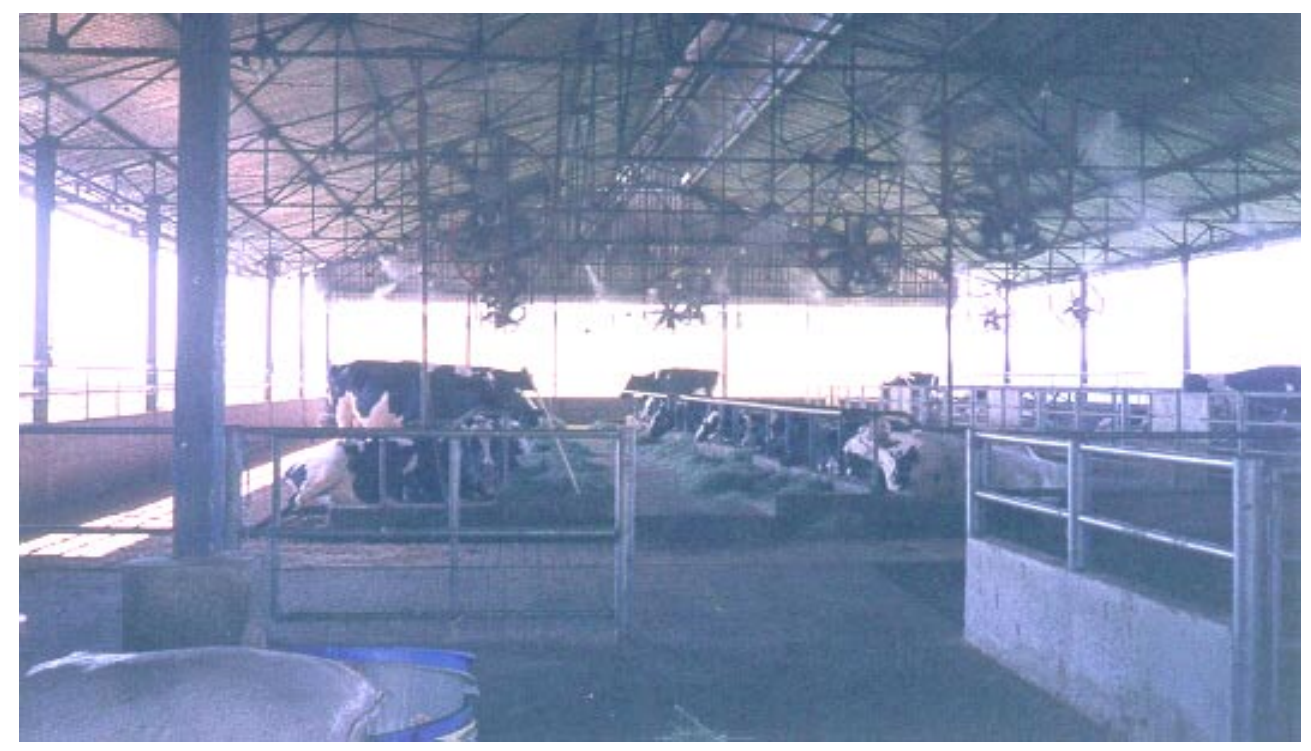

FIGURA 3.1 - Vista frontal da instalação tie-stall 


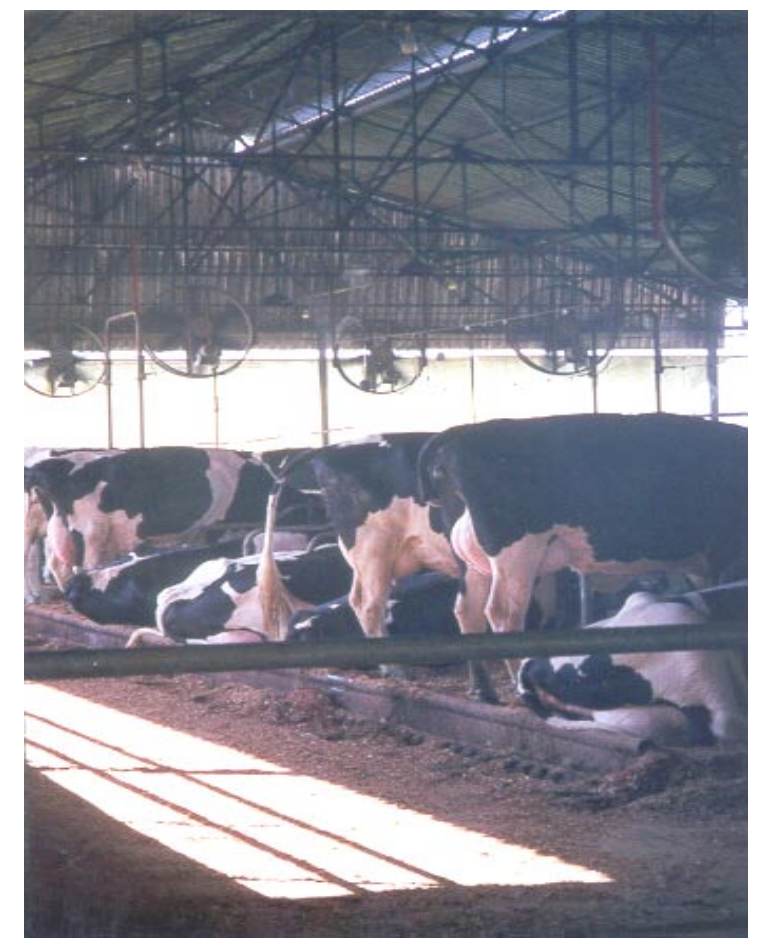

FIGURA 3.2 - Vista de perto mostrando detalhes do tie-stall.

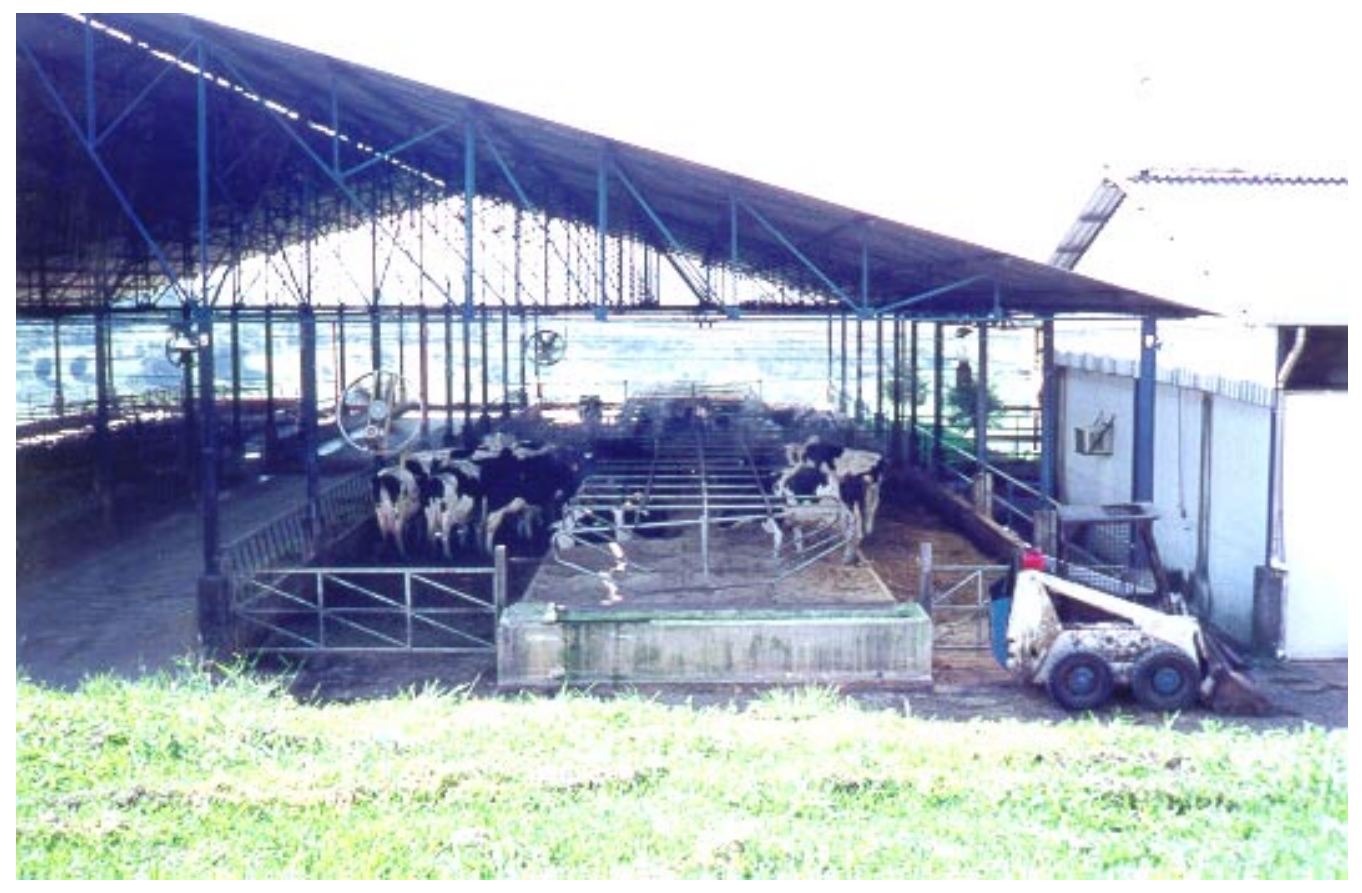

FIGURA 3.3 - Vista mostrando instalação de free-stall e corredor de alimentação 


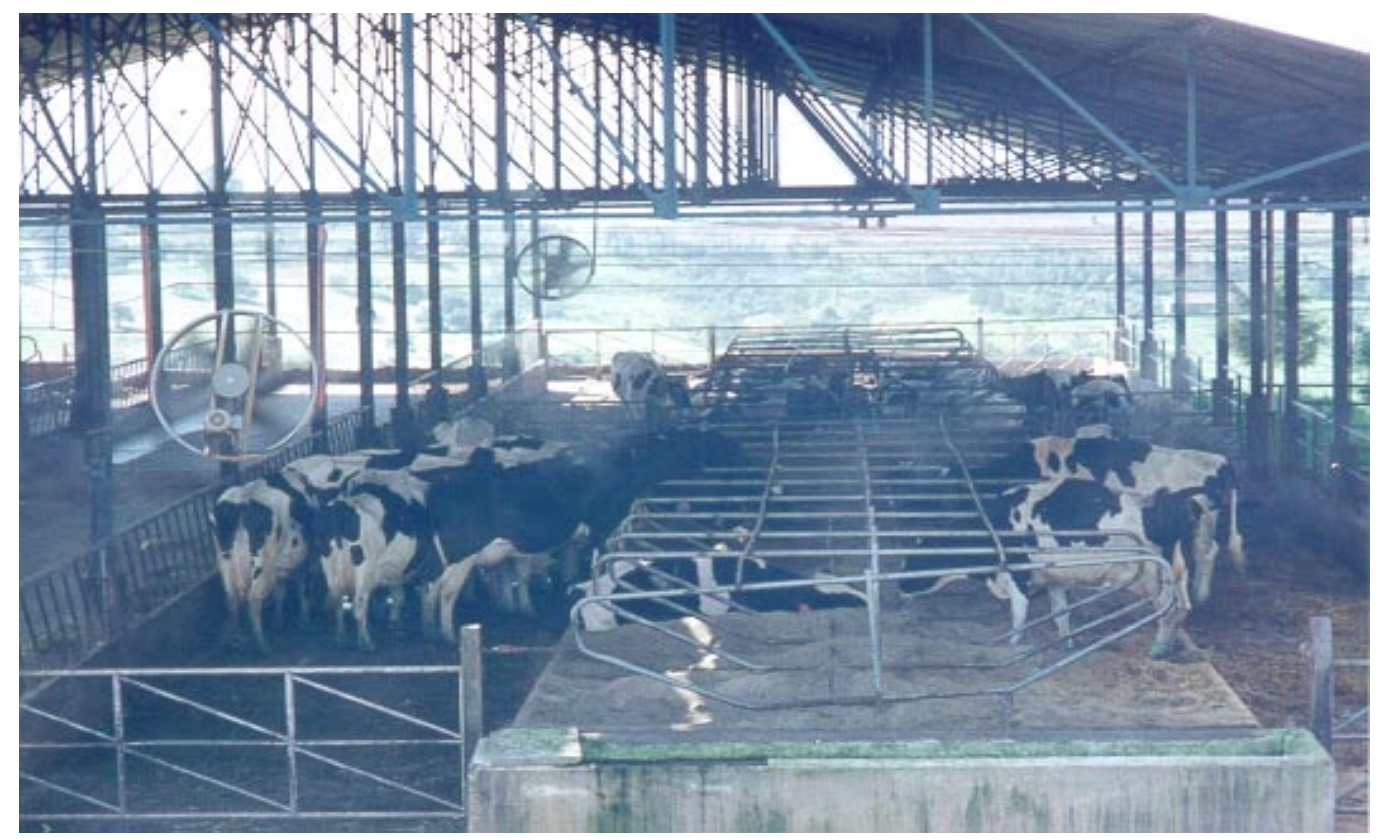

FIGURA 3.4 - Vista do free-stall, mostrando detalhes das baias individuais.

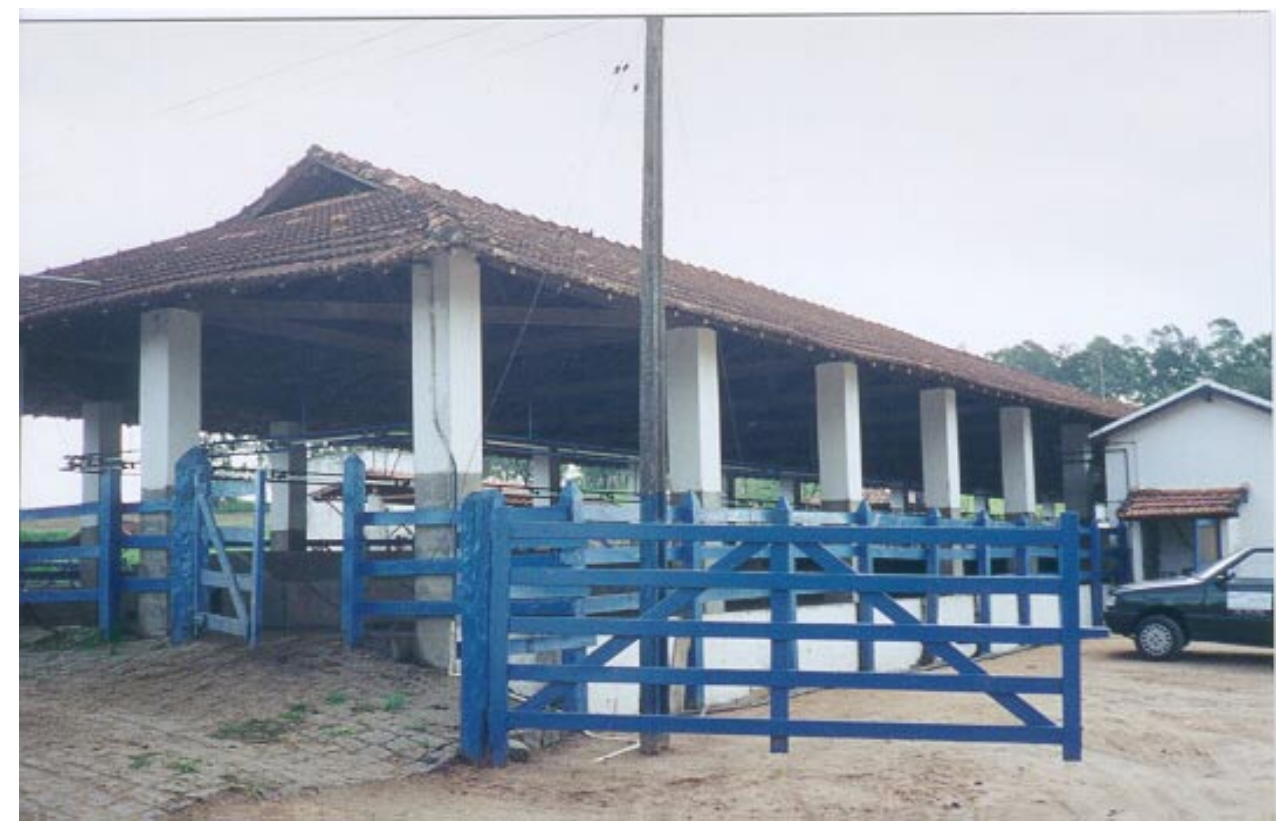

FIGURA 3.5 - Vista em perspectiva mostrando o estábulo de alimentação para as vacas manejadas sob pastejo contínuo. 


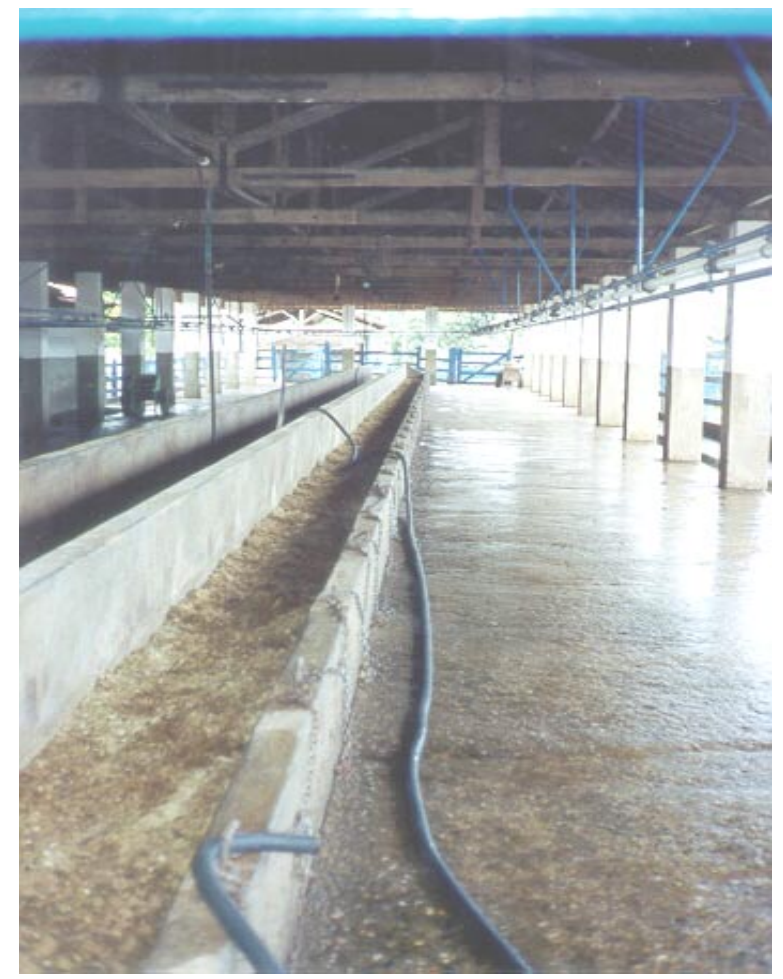

FIGURA 3.6 - Vista do interior do estábulo de alimentação.

A primeira fazenda, denominada de Fazenda Santa Terezinha (onde estão localizados os sistemas Free-stall e Tie-stall, está localizada no município de São José dos Campos, SP, mais especificamente no distrito de Eugênio de Melo, e a outra, denominada de Fazenda Santa Cruz, no município de Caçapava, SP, onde está localizado o sistema de pastejo contínuo.

\subsubsection{Tie-stall}

A instalação do tie-stall, como dito anteriormente, é contígua à do free-stall, ambas interligadas por um corredor coberto.

O tie-stall tem 30,0 m de comprimento e 14,0 m de largura, com pé-direito de 3,9 m. As telhas onduladas, são de cimento amianto. O telhado conta com lanternim na parte central do galpão, e beiral de $0,80 \mathrm{~m}$. Existem 12 ventiladores de $0,80 \mathrm{~m}$ de diâmetro, inclinação de aproximadamente $30^{\circ}$ em relação à vertical, e com motor de $372 \mathrm{~W}(0,5 \mathrm{HP})$ de potência, gerando um fluxo de ar de $28 \mathrm{~m}^{3}$ por minuto cada um. 
$\mathrm{Na}$ direção da largura do galpão, estão instalados seis linhas de nebulizadores, com 10 bicos em cada linha, funcionando por 2 minutos com 15 minutos de intervalo entre os funcionamentos. (Figuras 3.1 e 3.2)

O tie-stall está dividido em 18 baias de cada lado, forradas com cama de areia coberta com cavaco de madeira, onde as vacas permanecem constantemente presas pelo pescoço por uma corrente, só saindo para a ordenha, ou alguma outra necessidade esporádica. As baias têm dimensão de 1,45 m por 2,10 m, separadas por um corredor central de 2,0 m, onde é servida a alimentação (Figura 3.1 e 3.7).

O piso do tie-stall é de cimento, com superfície áspera para que as vacas não escorreguem enquanto estiverem transitando da ordenha para as baias e vice-versa.

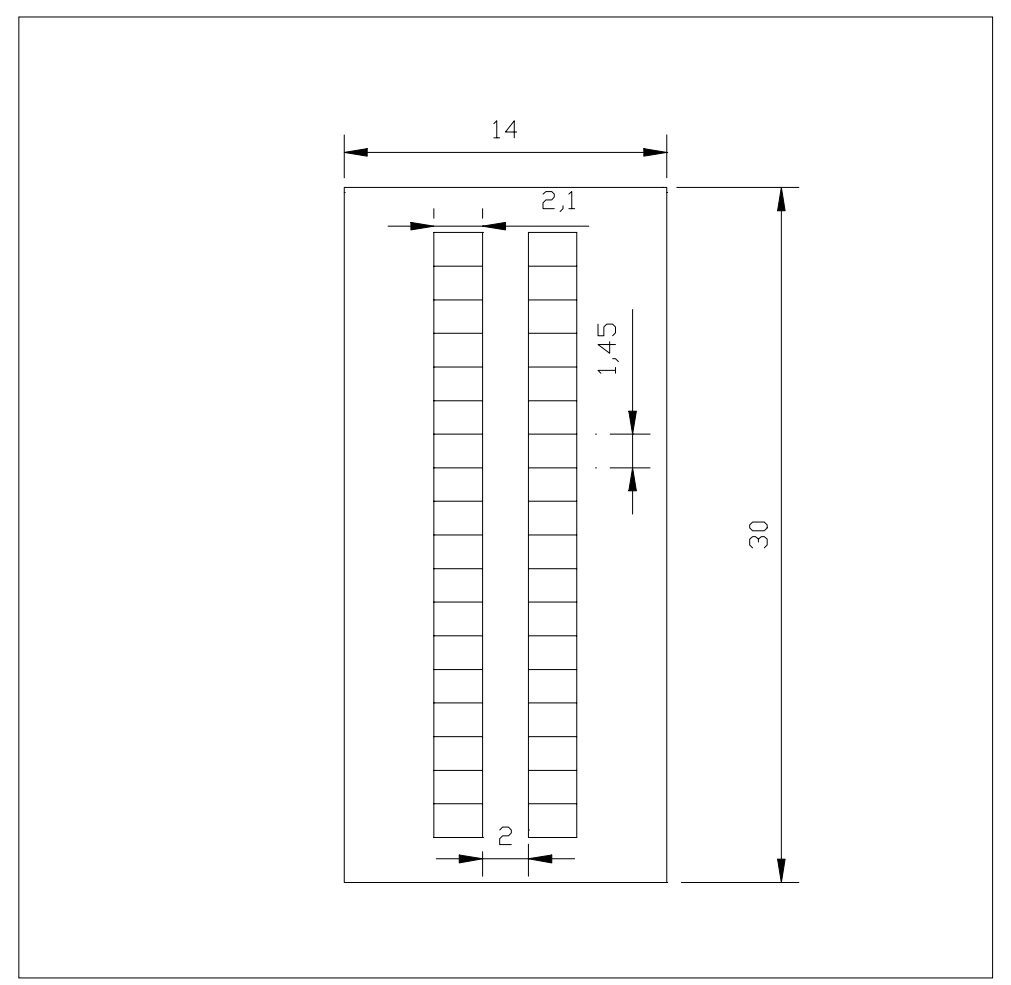

FIGURA 3.7- Esquema do tie-stall, com disposição das baias. Sem escala, medida em $\mathrm{m}$. 


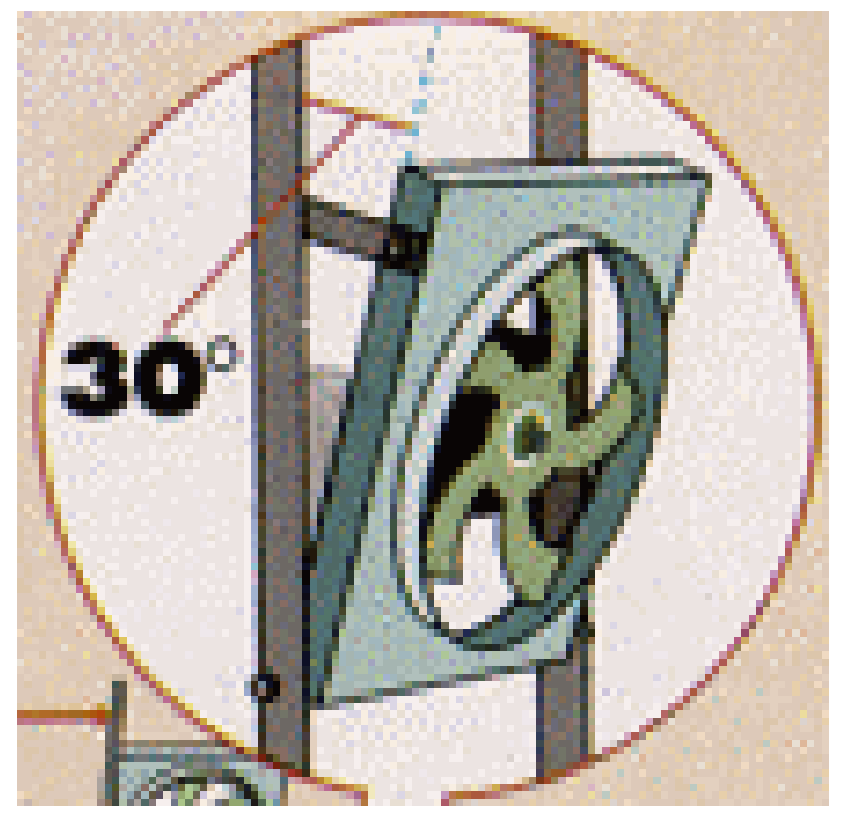

Figura 3.8 - Detalhe mostrando a inclinação do ventilador.

\subsubsection{Free-stall}

O free-stall tem 40,2 $\mathrm{m}$ de comprimento por $26,9 \mathrm{~m}$ de largura. Na sua direção transversal, existe um corredor central de 3,0 m, que divide o galpão em duas metades e por onde passam as vacas para serem ordenhadas. Na direção longitudinal, também há um corredor central de 4,9 m, que é chamado corredor de alimentação; nele é fornecida a alimentação para as vacas, sobre o piso, a qual fica constantemente à disposição delas. Esses corredores fazem com que o galpão de free-stall seja subdividido em quatro partes iguais de $18,6 \mathrm{~m}$ por $11,0 \mathrm{~m}$ (Figura 3.8). O pé-direito do galpão também é de 3,9 m, sendo que o beiral é de $0,80 \mathrm{~m}$. A cobertura do galpão é de telha ondulada de cimento amianto e seu piso é de concreto áspero, com inclinação na área de trânsito dos animais de $2 \%$. 


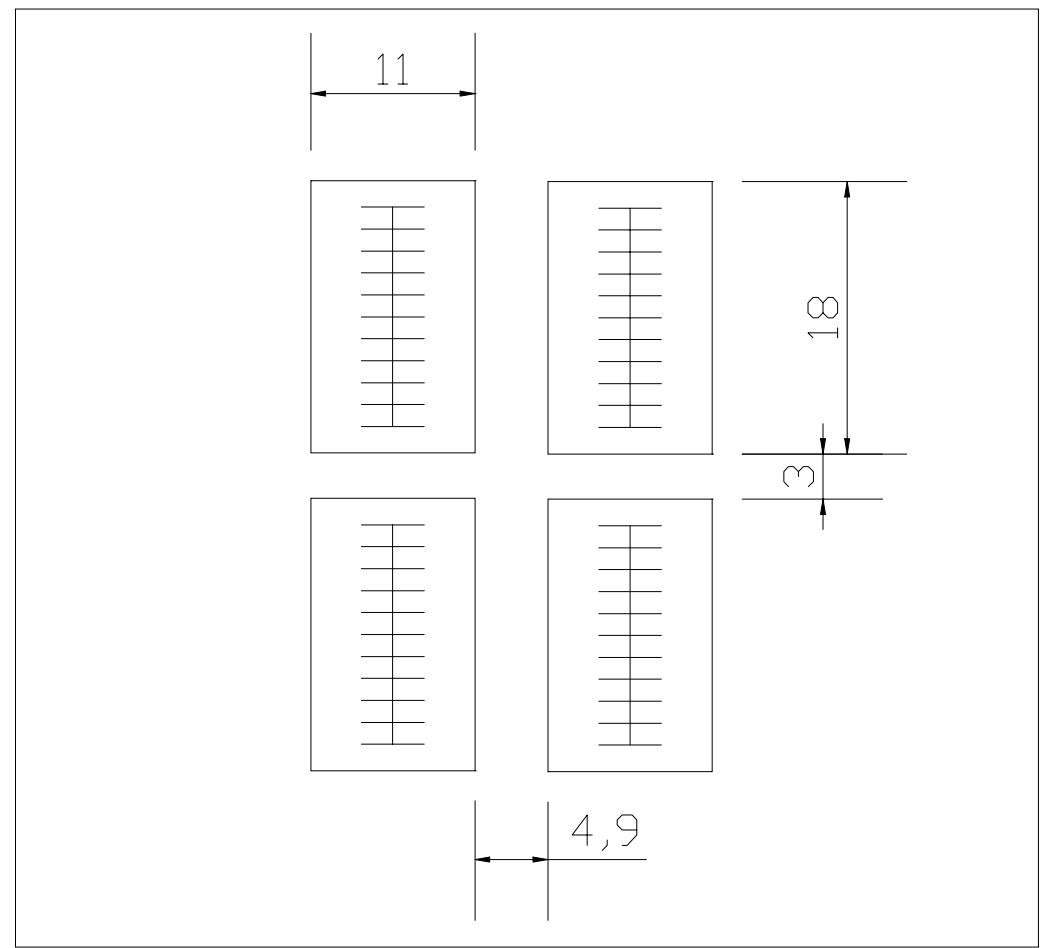

FIGURA 3.8a - Esquema do free-stall e com disposição das baias. Sem escala, medida em $\mathrm{m}$.

Cada uma dessas partes do galpão conta com um ventilador de $0,80 \mathrm{~m}$ de diâmetro, inclinação de aproximadamente $30^{\circ}$ em relação à vertical, e com motor de $372 \mathrm{~W}(0,5 \mathrm{HP})$ de potência gerando um fluxo de ar de $28 \mathrm{~m}^{3}$ por minuto, com a finalidade de ventilar as vacas no corredor de alimentação, conforme Figura 3.9 Cada uma dessas quatro partes também é servida por três linhas de nebulizadores, com seis bicos em cada uma das linhas, os nebulizadores são programados para funcionarem por 2 min a intervalos de 15 minutos entre eles. 


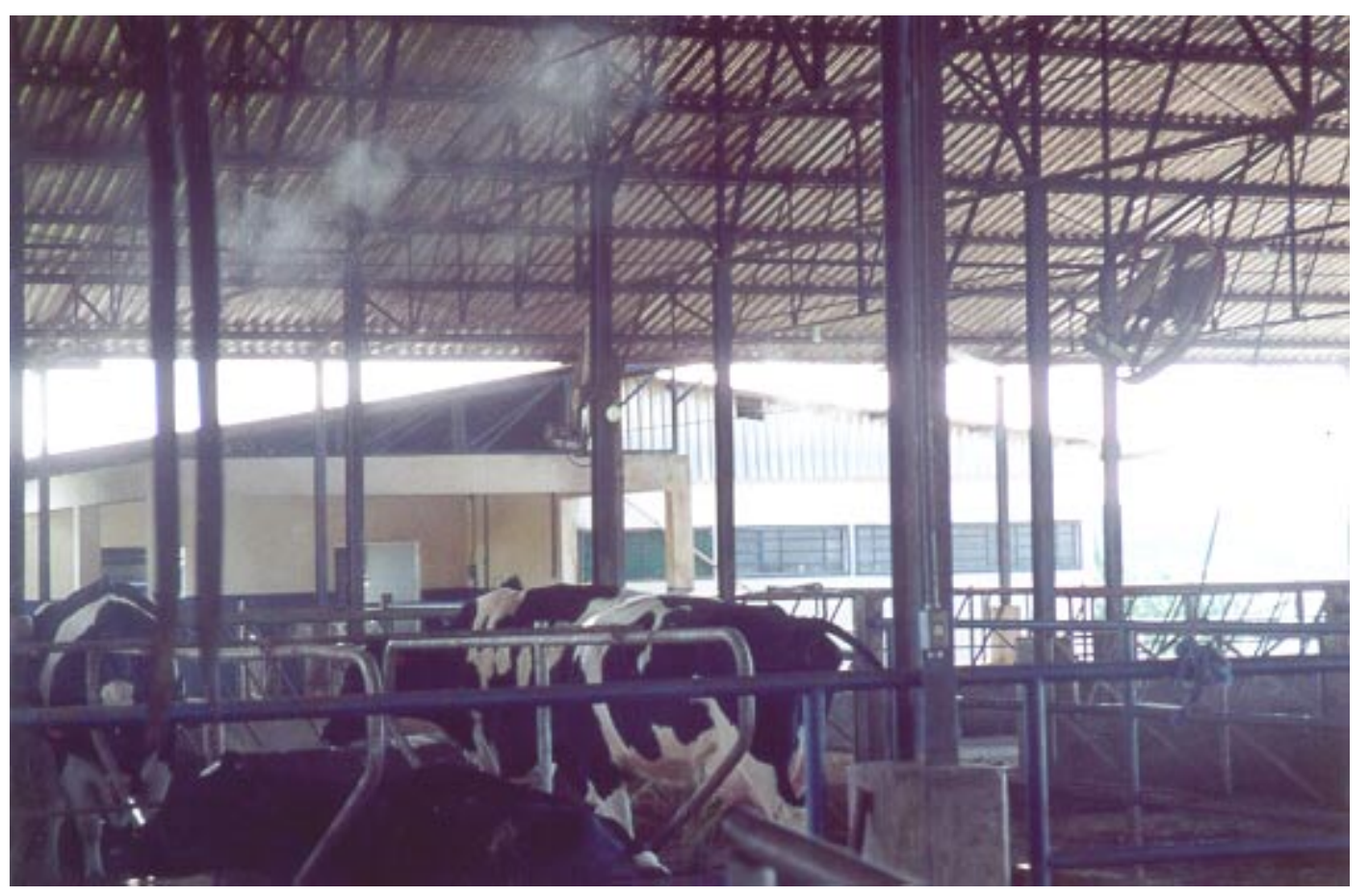

FIGURA 3.9 - Foto demonstrando detalhes de ventilador e nebulizador.

Cada quarto do galpão tem 20 baias individuais, sendo 10 frente a frente com as outras 10. Cada baia é forrada com cama de areia.

As vacas ficam constantemente presas neste curral, só saindo para a sala de ordenha junto ao galpão.

\subsubsection{Pastejo Contínuo}

O galpão de alimentação mede 44,60 m por 9,44 m de largura, onde as vacas ficam alojadas, em número de 33 animais de cada lado, frente a frente e com um estreito corredor central de $0,90 \mathrm{~m}$ para alimentação (Figura 3.10). O pé-direito é de 2,90 m, com beiral de $0,60 \mathrm{~cm}$ e a cobertura do estábulo é de telha de barro (francesa) (Figuras 3.5 e 3.6). Neste sistema não está instalado nenhum sistema de climatização, visando diminuir as condições atmosféricas desfavoráveis aos animais no interior do galpão. 


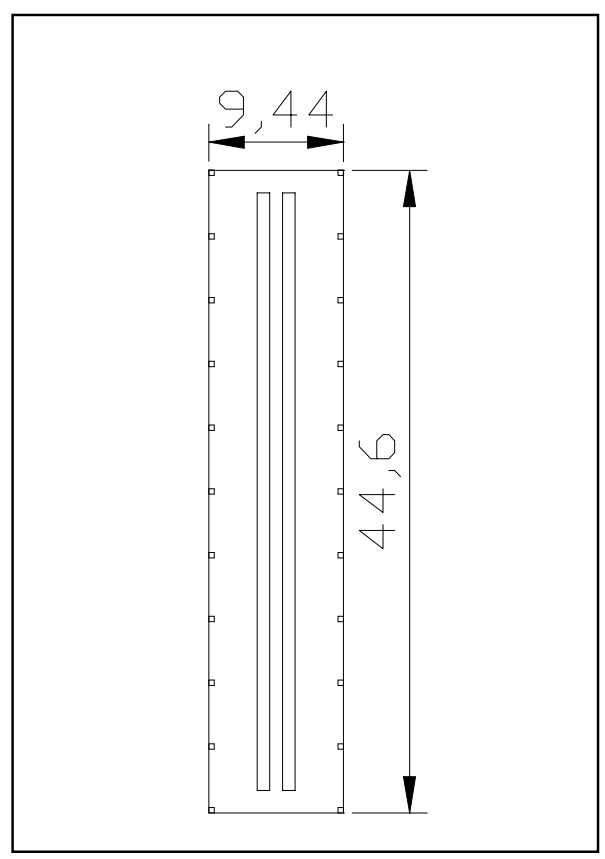

FIGURA 3.10 - Esquema do estábulo para alimentação das vacas e com disposição do cocho. Sem escala, medida em m.

\subsection{Monitoramento das Instalações}

Dados coletados no interior das instalações: velocidade do ar, temperatura de bulbo seco (máxima/mínima do ambiente), temperatura de globo negro e umidade relativa, na altura média de $2 \mathrm{~m}$ do solo, o mais perto possível do centro geométrico dos galpões, sem atrapalhar a livre circulação dos animais e tratadores, e também longe do alcance das vacas aos instrumentos de medição.

As Figuras 3.11, 3.12 e 3.13 ilustram o posicionamento dos instrumentos de medida no interior dos galpões, respectivamente do tie-stall, do free-stall e do curral de alimentação, para as vacas submetidas a manejo de pastejo contínuo. A instrumentação foi distribuída ao longo das áreas cobertas de permanência de animais, com quatro coletas diárias de dados, (às 7, 11, 13 e 17 h) para as instalações de free-stall e tie-stall, e três coletas diárias (às 7, 13 e 17 h) para a instalação da propriedade com manejo de pastejo contínuo, sendo que, a não coleta de dados às 11 horas deveu-se à indisponibilidade de mão-de-obra para se fazer estas coletas, durante o período de 15 de janeiro a 30 de março de 2000 . 
Foram ainda instalados externamente nas propriedades das instalações de Tiestall e Free-stall, um pluviômetro, termômetro de máxima/mínima, termômetro de globo negro, higrômetro e anemômetro, para medidas ambientais comparativas (Figuras 3.14 e 3.15) Segue a identificação das medições e dos instrumentos empregados:

Para a coleta de temperaturas máxima e mínima foi usado termômetro de bulbo seco de máxima/mínima marca Incoterm, com coluna de mercúrio, escala entre $38,0^{\circ} \mathrm{C}$ e $+50,0^{\circ} \mathrm{C}$ e com menor divisão igual a $1,0^{\circ} \mathrm{C}$.

- A temperatura de globo negro foi medida com termômetro de globo, formado pela associação de um termômetro de coluna de mercúrio, da marca Arbacom, escala de $-10,0^{\circ} \mathrm{C}$ e $+150,0^{\circ} \mathrm{C}$, e menor divisão de $0,1^{\circ} \mathrm{C}$, com sua base inserida no centro geométrico de uma esfera plástica pintada com tinta da cor preta fosca. Houve vedação completa do orifício produzido para inserção do termômetro no globo, conforme NÄÄS et al. (1993).

- A velocidade do vento foi medida, no exterior dos galpões, por um anemômetro mecânico de conchas da marca Hidrologia, com medidor analógico e precisão de $0,1 \mathrm{~km} / \mathrm{h}$. A velocidade no interior dos galpões foi medida com um anemômetro digital da marca Iope, com escala de 0,0 a $35,0 \mathrm{~m} / \mathrm{s}$ e precisão de $0,1 \mathrm{~m} / \mathrm{s}$.

- A precipitação pluviométrica foi medida com o auxílio de pluviômetro de aço inoxidável marca Apager (pluviômetro tipo H.H. em aço inox, com $300 \mathrm{~cm}^{2}$ de área de captação, cintas de fixação e proveta graduada até $35 \mathrm{~mm}$ ), que armazenava a chuva que caia e era feita a medida de precipitação diária em mm, por meio de uma proveta graduada.

Todos os dados ambientais, coletados para o experimento, estão demonstrados no Anexo I. 


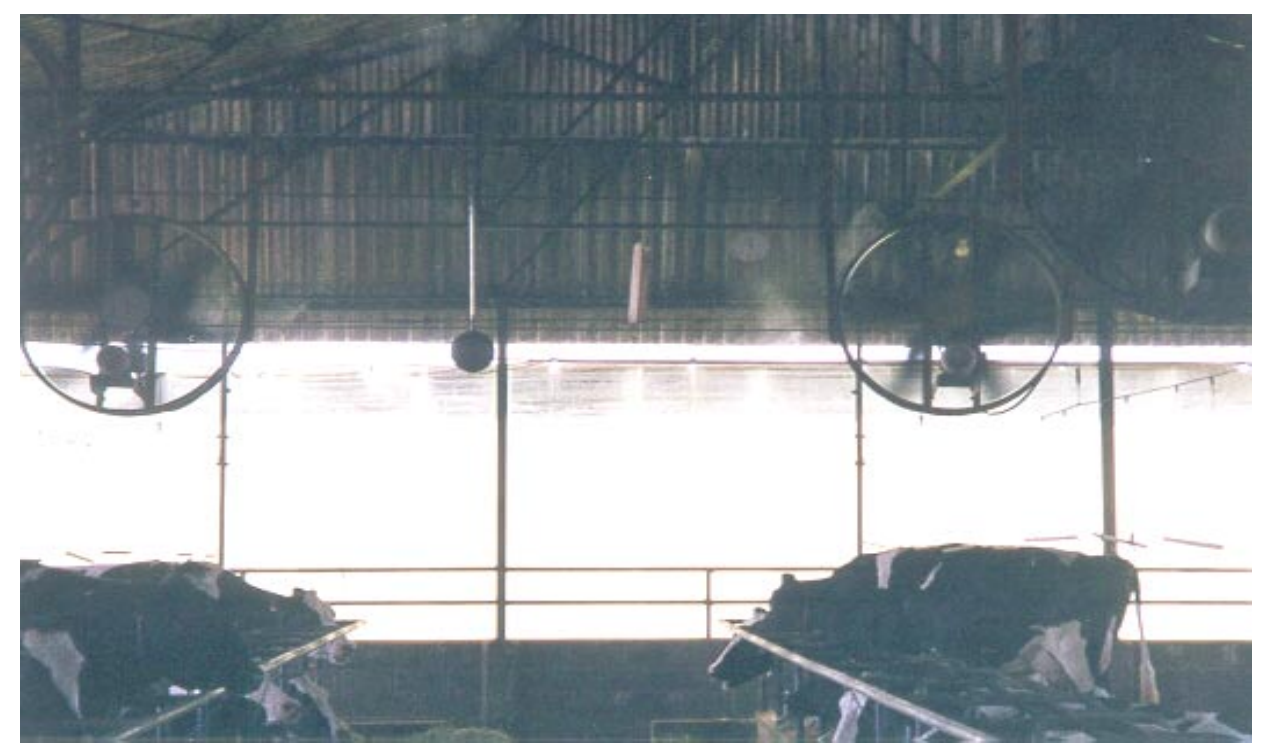

FIGURA 3.11 - Foto com detalhes dos instrumentos de monitoramento térmico no tie -stall.

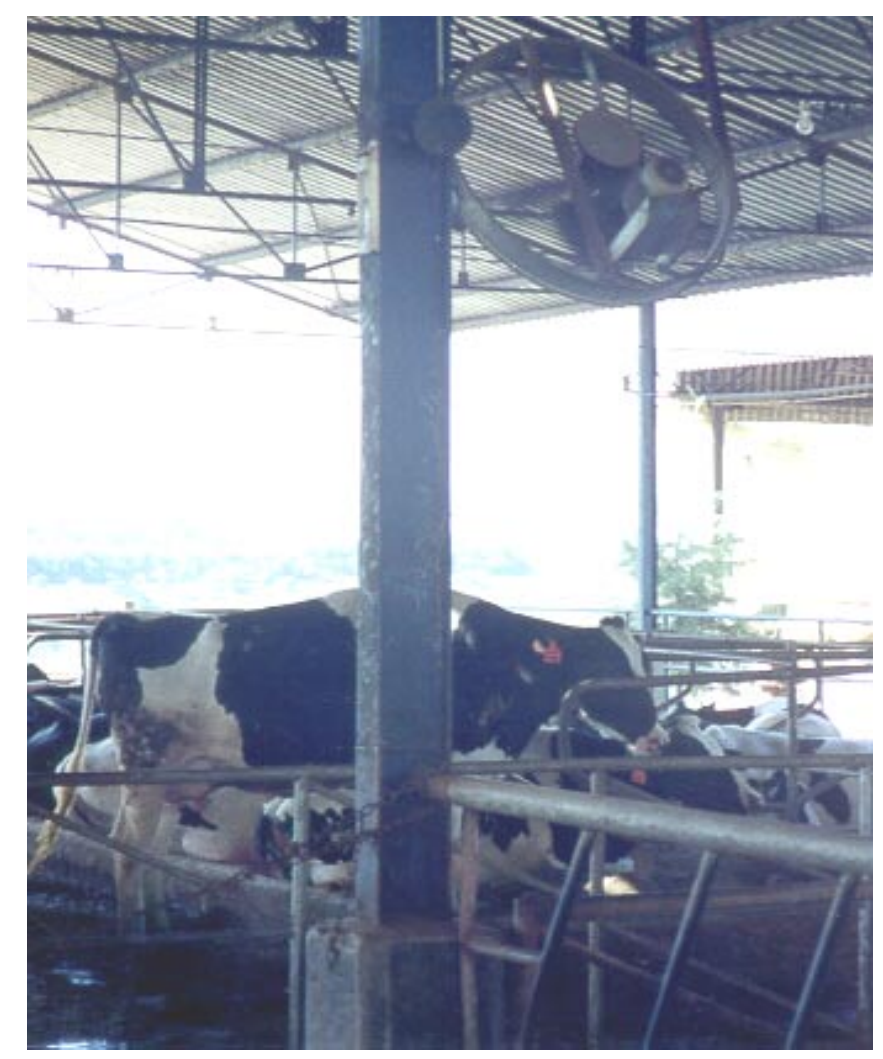

FIGURA 3.12 - Foto com detalhes dos instrumentos de monitoramento térmico no free-stall 


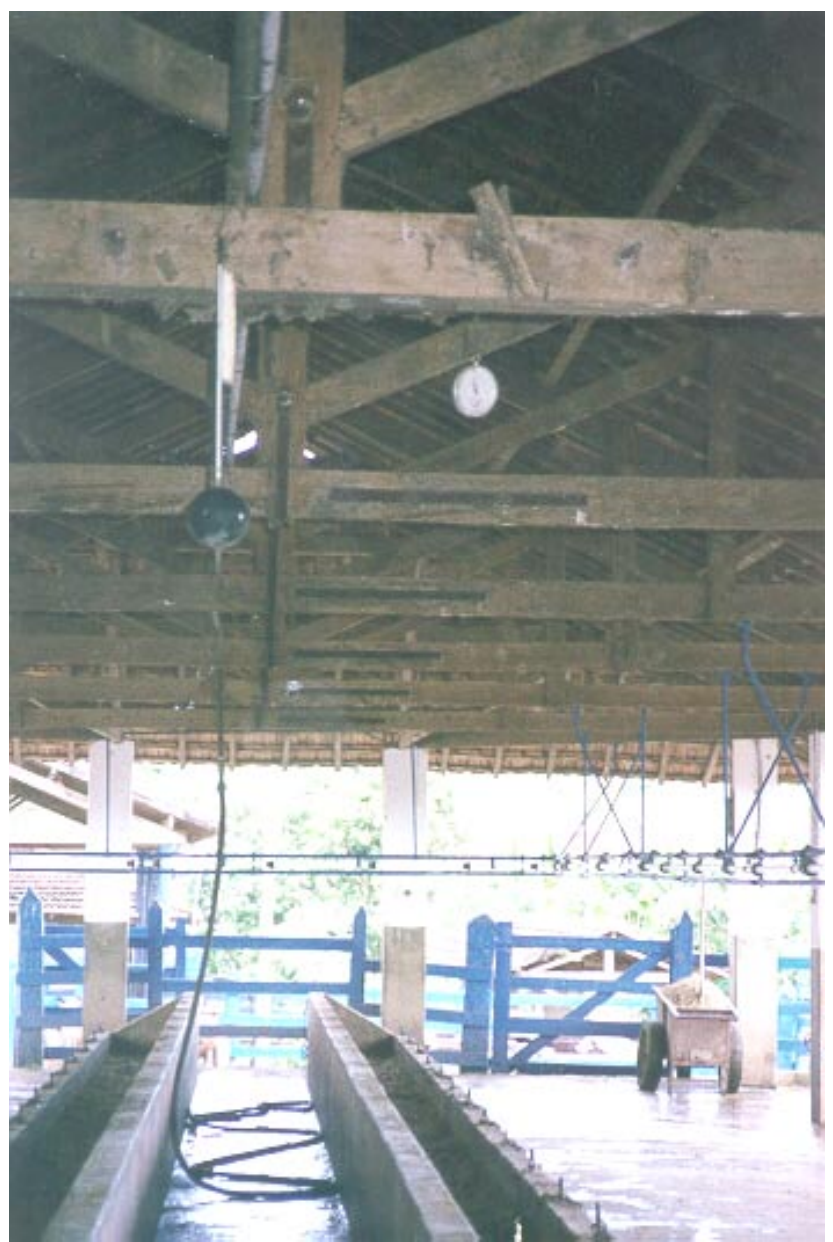

FIGURA 3.13 - Foto com detalhes dos instrumentos de monitoramento térmico no estábulo de alimentação para as vacas submetidas a pastejo contínuo.

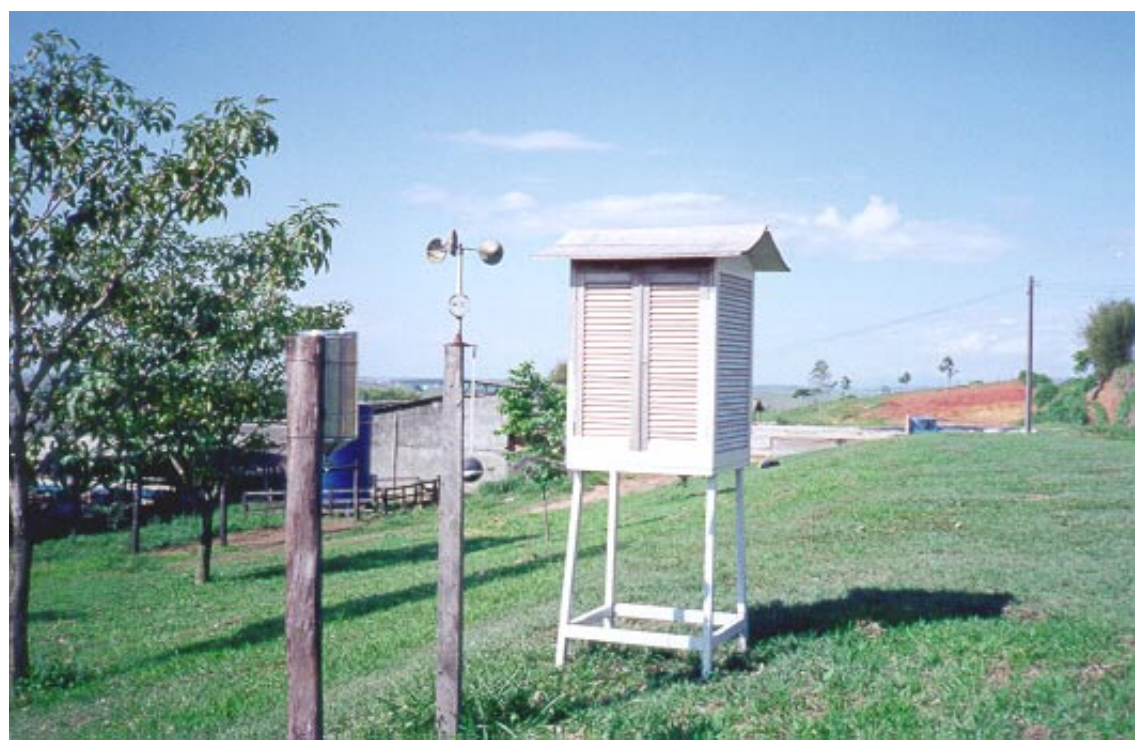

FIGURA 3.14 - Vista do abrigo meteorológico, do pluviômetro, do anemômetro e. do termômetro de Globo Negro. 


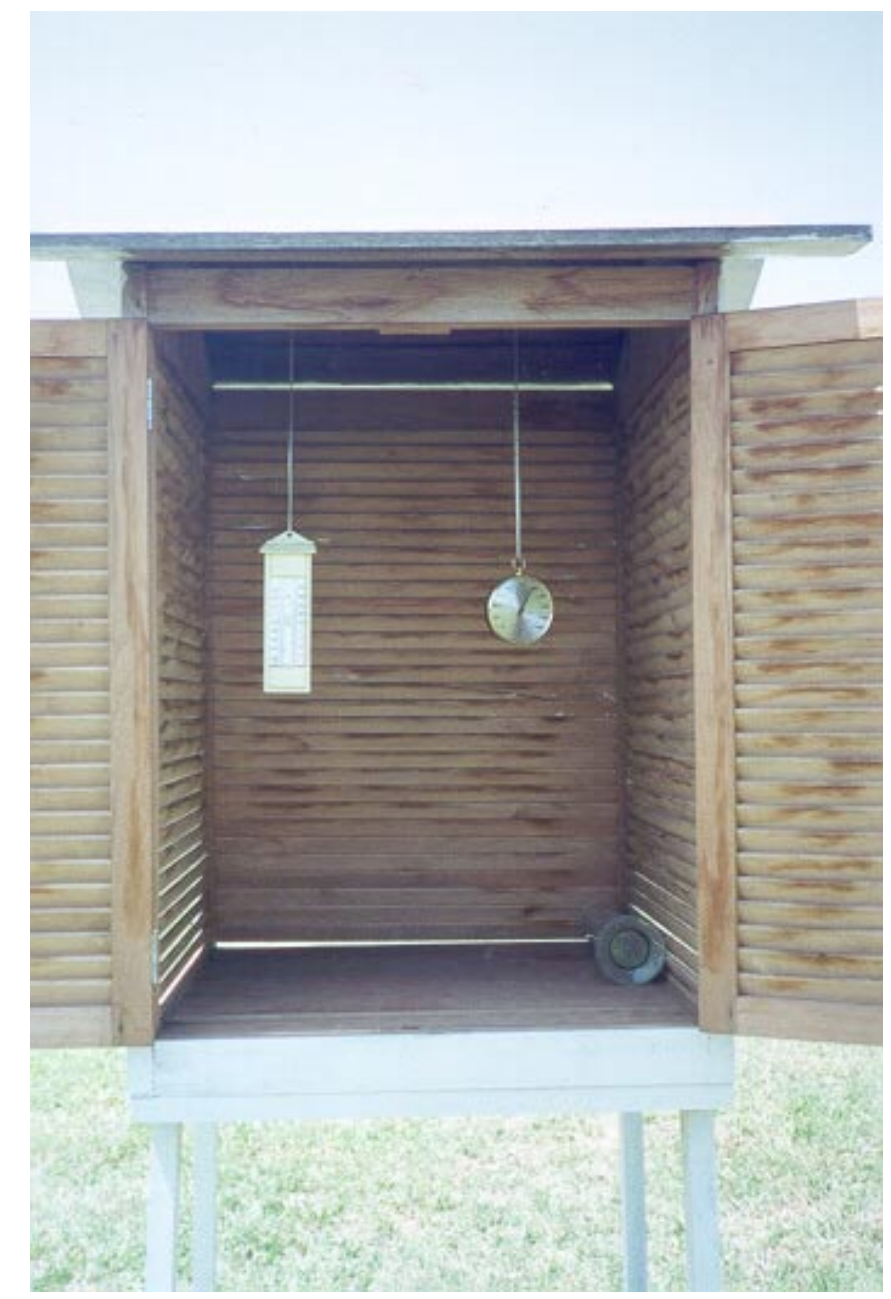

FIGURA 3.15 - Interior do abrigo meteorológico, mostrando termômetro de máx. e mín. e higrômetro.

\section{6. Índices de Conforto Térmico}

Para o presente trabalho, os índices selecionados para análise de conforto térmico, foram os seguintes: THI, ITGU e BGHI, já detalhados nos itens 2.2.1, 2.2.2 e 2.2.4, e nas fórmulas de $\mathrm{n}^{0} 2.1,2.3$ e 2.6, respectivamente. Os índices foram calculados com base em trabalho similar realizado por SAVASTANO JR. et al. (1997) e conforme definições feitas no item 2.2.

Dentre os vários índices disponíveis para se avaliar o conforto térmico dentro das instalações analisadas, escolhemos aqueles descritos anteriormente pelos seguintes motivos: o índice THI, também chamado por alguns autores de ITU, é um 
dos mais utilizados e relaciona-se a temperatura e a umidade relativa do ar; o ITGU considera, em sua formulação, a radiação solar, que é uma das mais importantes causas do estresse térmico para o homem e o animal e o BGHI que é indicativo de conforto térmico para vacas leiteiras expostas a ambientes de radiação solar direta e indireta.

O uso da entalpia, para seleção de períodos críticos, permitiu a identificação de situações adversas à zona de termoneutralidade (NÄÄS et al., 1995).

\subsection{Caracterização Econômica}

Paralelamente à análise de ambiência, foi feita a caracterização econômica de cada propriedade analisada, para se observar a influência das instalações e dos sistemas produtivos, na rentabilidade e sobrevivência das empresas.

As propriedades escolhidas para cada sistema produtivo em análise, apresentaram homogeneidade considerada aceitável, com relação aos seguintes parâmetros: produção média do rebanho, condições de relevo e altitude, padrão genético dos animais, conduta de nutrição e manejo, fácil acesso a registros técnicos e contábeis, interesse do proprietário e estabilidade do negócio. Os parâmetros listados acima foram analisados a partir das peculiaridades de cada sistema, a saber: estabulação total (tie-stall), estabulação livre (free-stall) e criação a pasto. As propriedades eram ainda representativas de um número significativo de empresas na região.

A coleta de dados de campo para avaliação econômica, teve início em maio de 1999, com término em abril de 2000, nas duas fazendas, para processamento das planilhas de custo da produção de leite. Tais planilhas foram elaboradas com base no aplicativo de informática de controle de custos para a pecuária leiteira, o Custo Leite, da empresa Soluções Informatizadas para Negócios (SIN), em parceria com o Prof. Marcos Aurélio Lopes (LOPES, 2000), da Universidade Federal de Lavras, MG. Estudos publicados por GOMES (1997), RIBEIRO \& SAVASTANO JR. (1997) e SAVASTANO JR. et al. (1995), bem como os anais do Seminário sobre Metodologias de Cálculo do Custo de Produção de Leite (1999), também serviram de 
referência. A metodologia utilizada foi a de custos operacionais, sugerida por MATSUNAGA et al. (1976).

Para os cálculos da depreciação foi utilizado o método linear conforme explicação de HOFFMANN et al. (1981). Para os cálculos de margem bruta (diferença entre o valor da produção comercializada e os custos variáveis para produzi-la), margem líquida (diferença entre o valor da produção comercializada e os custos totais para produzi-la) e ponto de equilíbrio (produção de leite mínima necessária para que seus custos empatem com a receita), o software utiliza a metodologia adotada por REIS (1986).

A fim de se calcular o custo operacional efetivo (COE) o programa Custo Leite, dividiu os desembolsos em dinheiro efetuados para o desenvolvimento da atividade em mão-de-obra, alimentação, sanidade, reprodução, ordenha, impostos e despesas diversas (LOPES e LOPES, 1999).

Os modelos das planilhas de campo seguem no Anexo II, para uso do programa Custo Leite.

Os índices econômicos calculados foram rentabilidade (preço vs custo) do leite e da atividade leiteira, onde se apresentam os seguintes resultados: total das receitas, custo operacional total, custo operacional efetivo, custo com depreciação, custo total, custos fixos, remuneração da terra, remuneração do capital investido e remuneração do empresário. Estabeleceu-se também o preço mínimo do leite, necessário à sobrevivência de cada criador (ALVES, 1999).

A análise do custo de produção de leite usou a metodologia desenvolvida pelo Instituto de Economia Agrícola (IEA), em 1976, tendo como base o custo operacional efetivo, custo operacional total e custo total, em detrimento do sistema tradicional de custo fixo, custo variável e custo total, por se considerar aqui o primeiro método como de fácil entendimento pelo produtor. Seguem as definições para alguns dos conceitos empregados:

- Custo operacional efetivo (COE). São todos os desembolsos em dinheiro realizados na condução da atividade, isto é, todos os custos-caixa durante o ano. É o caso de alimentação (registro quantitativo diário de concentrados, forragens verdes, feno, silagem de milho e sorgo), mão-de-obra contratada, serviços e 
produtos veterinários, inseminação artificial e transferência de embriões, sementes, adubos, fertilizantes, combustível, lubrificantes, energia elétrica, reparos de benfeitorias, reparos de máquinas e equipamentos, transporte do leite, registro genealógico, aluguel e despesas gerais.

- Custo operacional total (COT). São todos os custos listados como COE acrescido dos custos correspondentes à mão-de-obra familiar (que, mesmo não recebendo salário, tem um custo), depreciação de benfeitorias, máquinas, animais adultos, pastagens e culturas perenes, que sofrem desgaste contínuo.

- Custo total (CT). É o COT acrescido da remuneração do capital investido em benfeitorias, máquinas, animais, terra e capital de giro. Foi arbitrado o valor de aluguel (custo de oportunidade) da terra diretamente utilizada pela atividade leiteira, em cada sistema produtivo, como o equivalente a um litro de leite tipo "C" por dia e por hectare, que é a média cobrada na região do experimento.

- Receita. Leite, animais, esterco e outros produtos diretos da exploração leiteira.

\subsection{Análise estatística}

Foi realizado um delineamento inteiramente casualizado, com quatro tratamentos (tie-stall, free-stall, campo e estábulo para alimentação) e 16 repetições, considerando-se cada dia analisado às $13 \mathrm{~h}$ como uma repetição. Como determinante de quais dias seriam analisados, foram considerados todos aqueles em que a entalpia era maior do que a apurada à temperatura de $24^{\circ} \mathrm{C}$ e a $76 \%$ de umidade relativa do ar $(78,276 \mathrm{~kJ} / \mathrm{kg}$ de ar seco).

Foram testados ainda os resultados de entalpia dos demais horários de coleta de campo $(8,11$ e $17 \mathrm{~h})$, na busca de diferença significativa entre eles. Quanto aos demais horários ( 8 e 17 h), as informações climáticas também não foram utilizadas para análise de conforto térmico, pois as médias da entalpia nesses horários foram significativamente inferiores àquelas dos horários de pico de calor.

Os dados ambientais foram submetidos à análise de variância utilizando-se o programa Statistica for Windows, v.5.1. H, 1997, e as médias dos tratamentos comparadas por intermédio do teste do Tukey (honest significant difference-HSD) a 
5\%, conforme trabalho de SAVASTANO JR. et al. (1997). Foram ainda verificadas as pressuposições de aplicação da técnica de análise de variância, isto é, se os valores obtidos eram ou não homogêneos. 


\section{RESULTADOS E DISCUSSÕES}

Com base no agrupamento e compatibilização dos dados de campo (monitorização das instalações de produção), o desempenho da atividade foi analisado estatisticamente para cada propriedade e sistema produtivo.

Como exposto no item 3.6., foram considerados críticos todos os dias em que, às $13 \mathrm{~h}$, a entalpia foi superior a 78,276 kJ/kg de ar seco, nas medidas feitas a campo, conforme demonstrado na Tabela 4.1.

Entende-se por dia crítico aquele em que a entalpia (grandeza que envolve temperatura ambiente e umidade relativa do ar, ou em outras palavras, quantidade de calor existente no ar) excede o limite de tolerância ao calor pelo animal homeotermo, que passa a sentir desconforto e, conseqüentemente, reduz sua capacidade produtiva.

Para o horário das $13 \mathrm{~h}$, os dias selecionados para estudo foram em número de 16 e estão considerados na Tabela 4.1, com base nos resultados de entalpia obtidos na área externa às instalações (campo).

Para as $11 \mathrm{~h}$, apesar de terem sido identificados 17 dias críticos (Tabela 4.2), a média das entalpias foi ligeiramente inferior à das $13 \mathrm{~h}$, entretanto, sem diferença estatística significativa (Tabela 4.3), daí a opção de cálculo dos índices de conforto apenas para as $13 \mathrm{~h}$ (itens 4.1 a 4.5 ).

Ocorreram diferenças significativas $(\mathrm{p}>0,05)$ entre as médias das 11 e das 13 h em relação às médias das 8 e das $17 \mathrm{~h}$, sendo que não ocorreram diferenças significativas $(p>0,05)$ entre as médias das 11 e das $13 \mathrm{~h}$. As entalpias obtidas às 13 $\mathrm{h}$ foram ligeiramente superiores às das $11 \mathrm{~h}$, sendo essa uma das razões para escolha dos dados das $13 \mathrm{~h}$ para análise. Quanto aos demais horários (8 e $17 \mathrm{~h})$, as informações climáticas também não foram utilizadas para análise de conforto térmico, pois as médias da entalpia foram significativamente inferiores àquelas dos horários de pico de calor (Tabela 4.3). 
Tabela 4.1. Dias críticos em termos de entalpia ( $\mathrm{kJ} / \mathrm{kg}$ de ar seco), às $13 \mathrm{~h}$, na área externa aos sistemas produtivos (campo). Em itálico e negrito estão assinalados os maiores valores para o dia.

\begin{tabular}{||c|c|c|c|c||}
\hline DIAS & TIE-STALL & $\begin{array}{c}\text { FREE- } \\
\text { STALL }\end{array}$ & ESTÁBULO & CAMPO \\
\hline $24 / \mathrm{fev} / 00$ & $\mathbf{8 4 , 1 9}$ & 63,05 & 83,68 & 84,16 \\
\hline $25 / \mathrm{fev} / 00$ & 78,49 & 80,63 & $\mathbf{8 6 , 1 3}$ & 85,66 \\
\hline $26 / \mathrm{fev} / 00$ & 76,91 & 64,69 & $\mathbf{8 5 , 8 7}$ & 81,17 \\
\hline $28 / \mathrm{fev} / 00$ & 79,11 & 66,88 & 82,77 & $\mathbf{9 3 , 3 0}$ \\
\hline $01 / \mathrm{mar} / 00$ & 66,64 & 73,30 & 79,76 & $\mathbf{8 4 , 5 3}$ \\
\hline $03 / \mathrm{mar} / 00$ & 67,80 & 63,94 & $7 \mathbf{9 , 2 8}$ & 79,27 \\
\hline $05 / \mathrm{mar} / 00$ & 67,19 & 60,94 & 86,67 & $\mathbf{8 8 , 9 2}$ \\
\hline $06 / \mathrm{mar} / 00$ & 79,25 & 73,26 & $\mathbf{8 5 , 9 9}$ & 83,67 \\
\hline $13 / \mathrm{mar} / 00$ & 68,25 & 69,05 & 73,90 & $\mathbf{9 9 , 2 9}$ \\
\hline 14/mar/00 & 65,18 & 53,91 & 78,09 & $\mathbf{8 0 , 4 2}$ \\
\hline 15/mar/00 & 72,87 & 79,21 & 78,09 & $\mathbf{8 2 , 6 3}$ \\
\hline 17/mar/00 & 82,89 & 75,29 & 83,65 & $\mathbf{9 7 , 8 6}$ \\
\hline 18/mar/00 & 78,03 & 78,76 & 81,17 & $\mathbf{1 0 2 , 8 8}$ \\
\hline 20/mar/00 & 73,48 & $\mathbf{8 1 , 5 0}$ & 79,33 & 79,76 \\
\hline 21/mar/00 & 73,77 & 69,83 & 73,01 & $\mathbf{7 9 , 3 3}$ \\
\hline 29/mar/00 & 67,34 & 67,34 & 73,89 & $\mathbf{8 1 , 0 5}$ \\
\hline Média & $73,84^{\text {a }}$ & $70,10^{\text {a }}$ & $80,70^{\text {b }}$ & $86,49^{\text {b }}$ \\
\hline $\begin{array}{l}\text { Desvio } \\
\text { padrão }\end{array}$ & 6,20 & 7,87 & 4,56 & 7,70 \\
\hline \hline
\end{tabular}

${ }^{a},{ }^{b}=$ letras diferentes, na mesma linha (média), ressaltam diferenças estatísticas para $\mathrm{p}<0,05$. 
Tabela 4.2. Dias críticos em termos de entalpia ( $\mathrm{kJ} / \mathrm{kg}$ de ar seco), às $11 \mathrm{~h}$, nas áreas externas aos sistemas produtivos (campo) em comparação com o interior das instalações. Em itálico e negrito estão assinalados os maiores valores para o dia.

\begin{tabular}{|c|c|c|c|}
\hline DIAS & TIE-STALL & FREE-STALL & CAMPO \\
\hline $21 / 02 / 00$ & 64,31 & 70,66 & 80,63 \\
\hline $24 / 02 / 00$ & 83,65 & 69,85 & 83,65 \\
\hline $25 / 02 / 00$ & 72,87 & 78,35 & 81,59 \\
\hline $26 / 02 / 00$ & 76,91 & 69,05 & 82,77 \\
\hline $27 / 02 / 00$ & 71,43 & 71,49 & 80,09 \\
\hline $29 / 02 / 00$ & 74,63 & 78,76 & 86,98 \\
\hline $03 / 03 / 00$ & 70,26 & 66,95 & 92,17 \\
\hline $05 / 03 / 00$ & 75,46 & 62,06 & 100,82 \\
\hline $06 / 03 / 00$ & 76,31 & 84,19 & 81,20 \\
\hline $07 / 03 / 00$ & 75,29 & 82,37 & 83,35 \\
\hline $11 / 03 / 00$ & 78,03 & 73,37 & 80,20 \\
\hline $17 / 03 / 00$ & 77,54 & 77,13 & 80,63 \\
\hline $18 / 03 / 00$ & 74,17 & 81,06 & 93,38 \\
\hline $21 / 03 / 00$ & 69,47 & 73,48 & 81,05 \\
\hline $22 / 03 / 00$ & 77,13 & 70,54 & 84,74 \\
\hline $24 / 03 / 00$ & 72,86 & 71,58 & 82,77 \\
\hline $29 / 03 / 00$ & 77,53 & 73,37 & 78,47 \\
\hline Média & $73,78^{\mathrm{a}}$ & $74,58^{\mathrm{a}}$ & $84,38^{\mathrm{b}}$ \\
\hline $\begin{array}{l}\text { Desvio } \\
\text { padrão }\end{array}$ & 4,29 & 5,83 & 5,88 \\
\hline
\end{tabular}

Tabela 4.3. Valores médios de entalpia ( $\mathrm{kJ} / \mathrm{kg}$ de ar seco) a campo as $11 \mathrm{e} 13 \mathrm{~h}$, nos dias críticos.

\begin{tabular}{||c|c||}
\hline \hline TIPO DE COBERTURA & ENTALPIA \\
\hline $11 \mathrm{~h}$ & $84,38^{\mathrm{a}}$ \\
\hline $13 \mathrm{~h}$ & $86,49^{\mathrm{a}}$ \\
\hline
\end{tabular}

a ${ }^{\mathrm{b}}=$ letras diferentes, na mesma coluna, ressaltam diferenças estatísticas para $\mathrm{p}<0,05$. 
Seguem os estudos comparativos de cada índice de conforto térmico analisado, entre as diversas instalações, para as $13 \mathrm{~h}$.

\subsection{Entalpia}

A Figura 4.1 indica que, com exceção de seis dias (24, 25 e 26 de fevereiro e 3, 6 e 20 de março), os índices de entalpia do campo foram maiores do que nas instalações. Em quatro destes seis dias (25 e 26 de fevereiro e 3 e 6 de março), o estábulo apresentou valores de entalpia superiores aos do campo. No dia 24 de fevereiro (apenas um dia), o índice de entalpia do tie-stall foi superior ao do campo, o mesmo acontecendo no dia 20 de março com o free-stall em relação ao campo. Isso demonstra a capacidade dessas instalações funcionarem como proteção contra a radiação solar na Região de São José dos Campos, SP. Na Figura 4.1, também está representada a entalpia que serviu de base para determinarmos os dias críticos $(78,276 \mathrm{~kJ} / \mathrm{kg} / \mathrm{ar}$ seco), que foi denominada de entalpia limite.

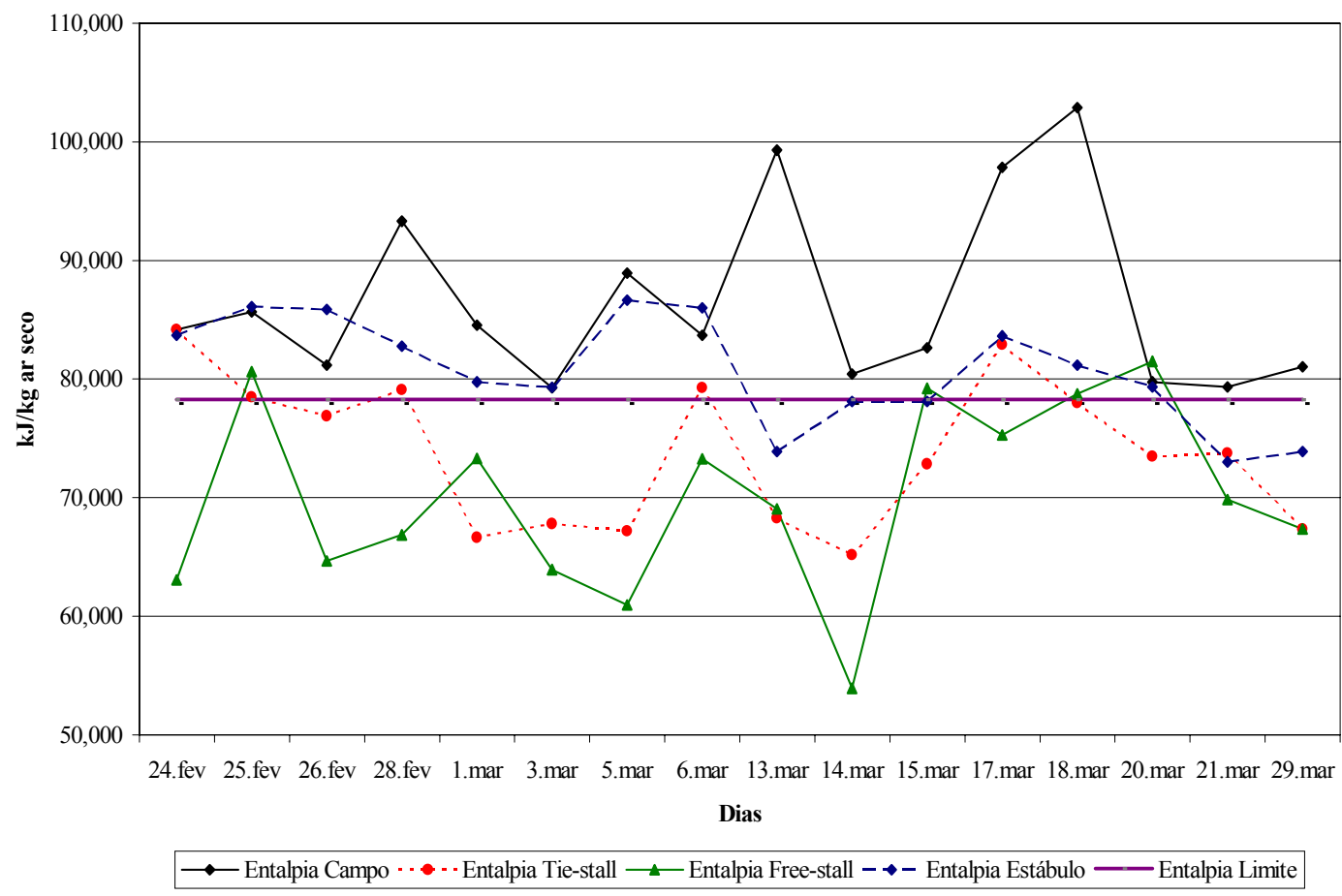

Figura 4.1. Variação da entalpia às $13 \mathrm{~h}$ nos diversos tipos de instalação nos dias críticos. 
Provavelmente, o fato de, no dia 24 de fevereiro e no dia 20 de março, ocorrerem valores desconfortantes para os animais no tie-stall e no free-stall respectivamente, deve-se ao manejo incorreto dos instrumentos de apoio como ventilador e nebulizador, pois não existia um controle preciso da temperatura e umidade ambiente para serem ligados ou desligados. Como explicado anteriormente no item 2.3 (ARCARO JÚNIOR, 2000), o uso inadequado de ventilador e nebulizador, podem acarretar aumento do desconforto térmico para os animais ali alojados, em razão da elevação da umidade relativa do ar.

\section{2. Índice de Temperatura de Globo e Umidade (ITGU)}

A Figura 4.2 mostra que, com exceção de quatro dias (26 de fevereiro e 3, 6 e 20 de março), os índices de temperatura de globo e umidade (ITGU) observados no campo foram superiores aos demais (Tabela 4.4). Em três desses quatro dias (26 de fevereiro e 3 e 6 de março), o estábulo apresentou ITGU superior ao campo. Apenas em um dia (20 de março), o ITGU obtido no free-stall foi superior ao obtido no campo.

Tais dados confirmam a eficiência do tie-stall e free-stall em relação ao estábulo, no sentido de proporcionarem, aos animais ali abrigados, maior conforto térmico na Região de São José dos Campos, SP. Esse fato foi confirmado com a análise estatística efetuada, que indica haver diferenças significativas $(\mathrm{p}<0,05)$ entre as médias de ITGU obtidas no estábulo e no campo, em relação àquelas obtidas no tie-stall e no free-stall, comprovando a eficiência de se controlar o meio ambiente das vacas através de auxílios (ventiladores e nebulizadores) que diminuem a temperatura e a umidade ambiente. 


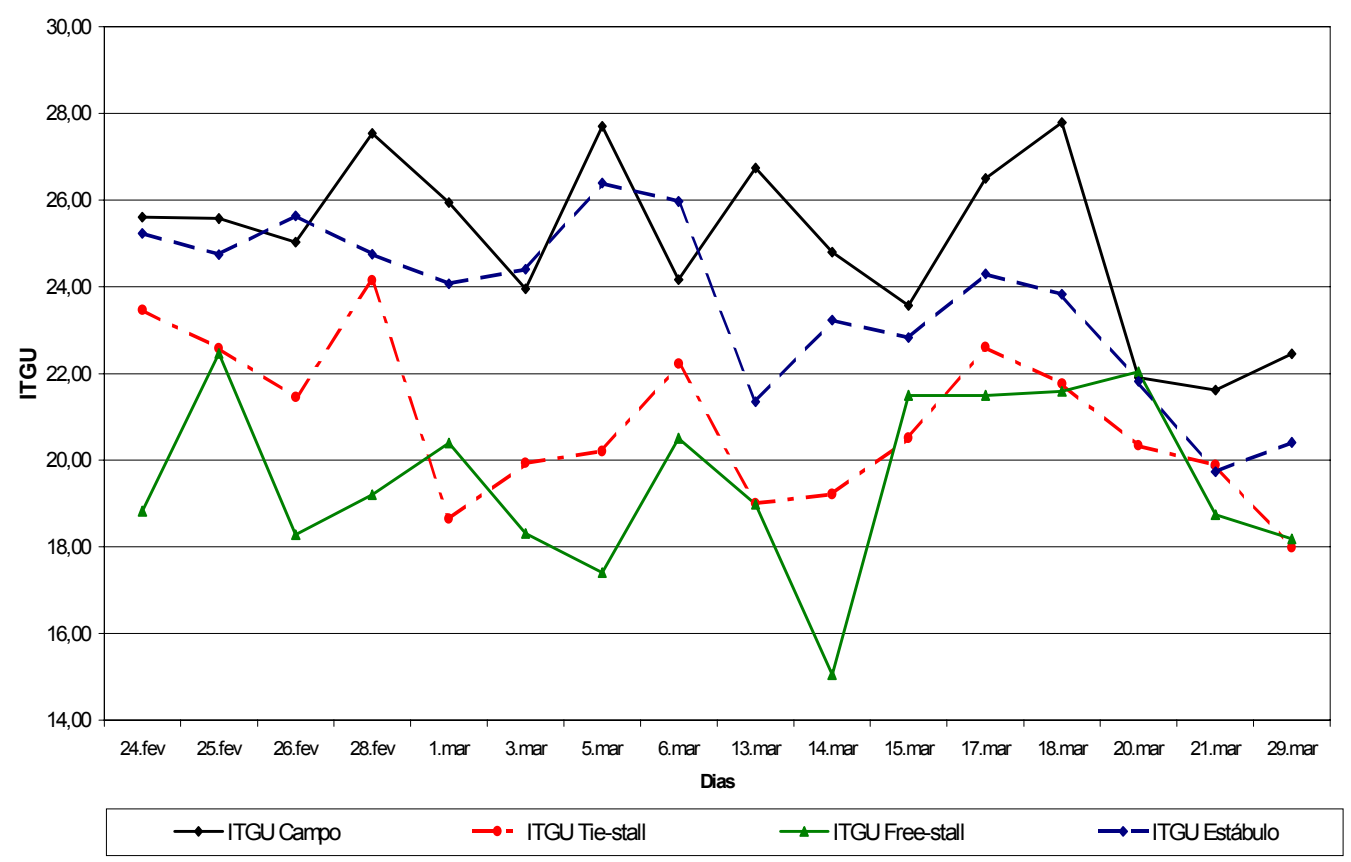

Figura 4.2 Comparação dos valores de ITGU para os diversos tipos de instalação nos dias críticos.

A Figura 4.2 também ilustra todos os valores de ITGU para as instalações estudadas nos 16 dias críticos.

Os valores de ITGU foram os que mais acompanharam as tendências da entalpia, no que se refere aos picos nas instalações relativas aos dias críticos. Isto é, os dias que tiveram o ITGU maior no campo (ou nas instalações), foram semelhantes aos da entalpia, com exceção dos dias 24 e 25 de fevereiro, conforme demonstrado nas Tabelas de $n^{\circ} 4.1$ e 4.4 . 
Tabela 4.4. Valores de ITGU para os dias críticos nas diferentes instalações e a campo às $13 \mathrm{~h}$. Em itálico e negrito estão assinalados os maiores valores para o dia.

\begin{tabular}{|c|c|c|c|c|}
\hline DIAS & TIE-STALL & $\begin{array}{l}\text { FREE- } \\
\text { STALL }\end{array}$ & ESTÁBULO & CAMPO \\
\hline $24 / \mathrm{Fev}$ & 23,46 & 18,82 & 25,23 & 25,61 \\
\hline $25 / \mathrm{Fev}$ & 22,58 & 22,46 & 24,74 & 25,57 \\
\hline $26 / \mathrm{Fev}$ & 21,45 & 18,28 & 25,64 & 25,03 \\
\hline $28 / \mathrm{Fev}$ & 24,14 & 19,21 & 24,75 & 27,54 \\
\hline 01/Mar & 18,65 & 20,40 & 24,07 & 25,94 \\
\hline 03/Mar & 19,93 & 18,31 & 24,40 & 23,95 \\
\hline 05/Mar & 20,21 & 17,41 & 26,40 & 27,70 \\
\hline 06/Mar & 22,22 & 20,50 & 25,96 & 24,17 \\
\hline 13/Mar & 19,00 & 18,98 & 21,35 & 26,75 \\
\hline 14/Mar & 19,22 & 15,05 & 23,23 & 24,79 \\
\hline 15/Mar & 20,51 & 21,50 & 22,83 & 23,57 \\
\hline 17/Mar & 22,60 & 21,50 & 24,29 & 26,50 \\
\hline 18/Mar & 21,76 & 21,59 & 23,83 & 27,79 \\
\hline 20/Mar & 20,33 & 22,03 & 21,81 & 21,90 \\
\hline 21/Mar & 19,89 & 18,74 & 19,72 & 21,61 \\
\hline 29/Mar & 17,99 & 18,19 & 20,41 & 22,46 \\
\hline Média & $20,87^{\mathrm{a}}$ & $19,56^{\mathrm{a}}$ & $23,67^{b}$ & $25,05^{\mathrm{b}}$ \\
\hline $\begin{array}{l}\text { Desvio } \\
\text { padrão }\end{array}$ & 1,80 & 1,99 & 1,97 & 2,00 \\
\hline
\end{tabular}

\section{3. Índice de Globo Negro e Umidade (BGHI)}

Os valores de BGHI para os dias críticos seguem ilustrados na Figura 4.3. Com exceção de um dia (6 de março), em que o índice verificado no estábulo foi superior ao do campo, em todos os outros dias, os valores de BGHI a campo foram sempre maiores que nas instalações (Tabela 4.5). 
Pela análise dos valores de BGHI obtidos, confirmam-se as indicações anteriores de que as instalações de tie-stall e free-stall, são mais adequadas em termos de proporcionar conforto térmico, para as vacas em lactação da raça Holandesa, variedade Preta e Branca, do que se estivessem a campo ou em estábulo convencional, na região de São José dos Campos, SP.

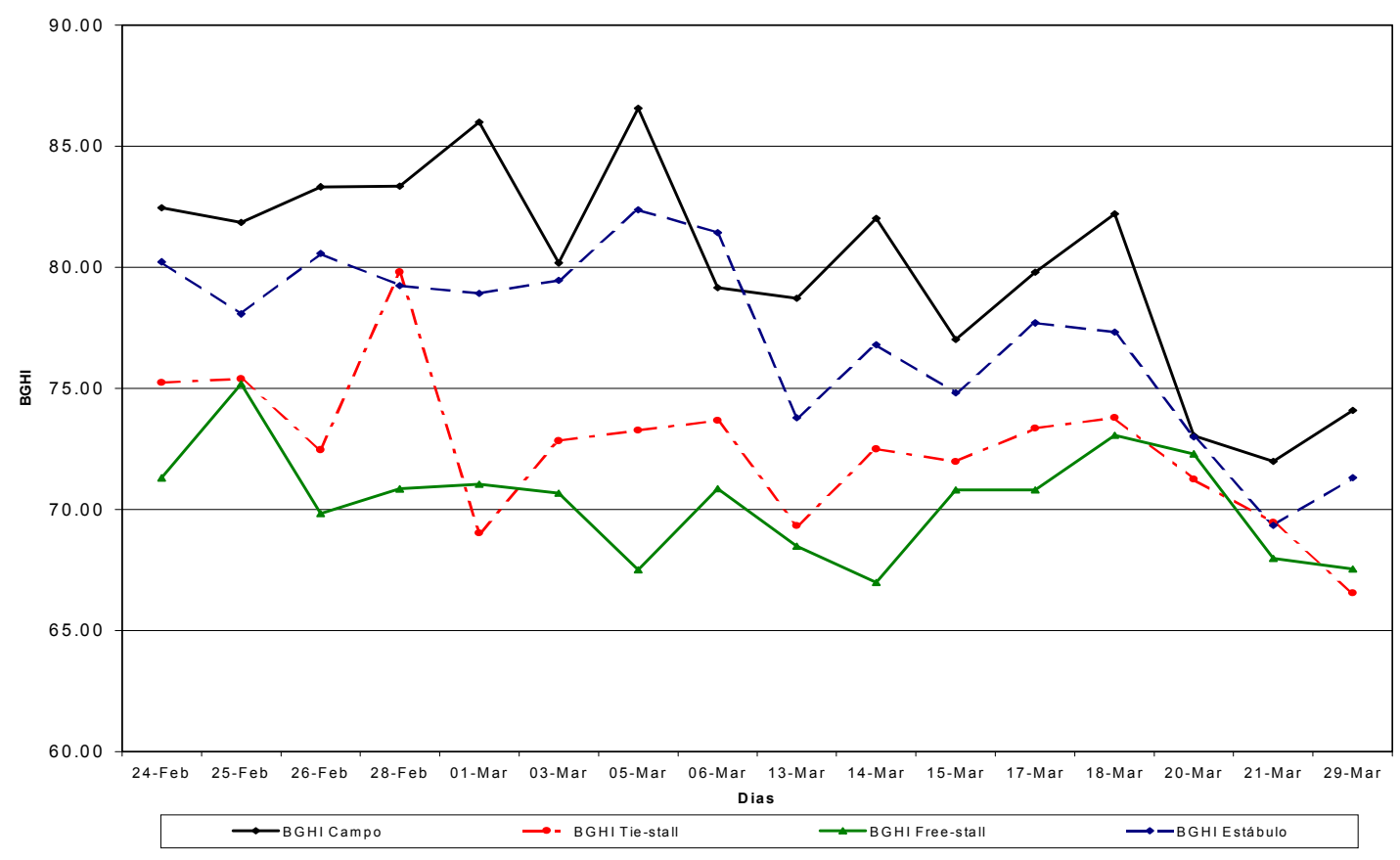

Figura 4.3. Comparação dos valores de BGHI para os diversos tipos de instalação nos dias críticos.

O BGHI foi o índice que melhor conseguiu diferenciar as instalações em relação ao campo, pois os valores obtidos a campo foram superiores aos das instalações, provavelmente devido ao fato de levar em conta a irradiação solar, por meio da temperatura de globo negro (tg), como exposto na equação 2.6 do item 2.2.4. 
Tabela 4.5. Valores de BGHI nos dias críticos nas diferentes instalações e a campo às

13 h. Em itálico e negrito estão assinalados os maiores valores para o dia.

\begin{tabular}{||c|c|c|c|c||}
\hline \hline DIAS & TIE-STALL & $\begin{array}{c}\text { FREE- } \\
\text { STALL }\end{array}$ & ESTÁBULO & CAMPO \\
\hline 24/Fev & 75,24 & 71,31 & 80,23 & $\mathbf{8 2 , 4 7}$ \\
\hline 25/Fev & 75,39 & 75,18 & 78,07 & $\mathbf{8 1 , 8 5}$ \\
\hline 26/Fev & 72,47 & 69,83 & 80,58 & $\mathbf{8 3 , 3 2}$ \\
\hline 28/Fev & 79,80 & 70,85 & 79,25 & $\mathbf{8 3 , 3 5}$ \\
\hline 01/Mar & 69,02 & 71,04 & 78,92 & $\mathbf{8 5 , 9 9}$ \\
\hline 03/Mar & 72,83 & 70,67 & 79,47 & $\mathbf{8 0 , 1 8}$ \\
\hline 05/Mar & 73,26 & 67,50 & 82,38 & $\mathbf{8 6 , 5 7}$ \\
\hline 06/Mar & 73,67 & 70,86 & $\mathbf{8 1 , 4 3}$ & 79,16 \\
\hline 13/Mar & 69,32 & 68,48 & 73,80 & $\mathbf{7 8 , 7 2}$ \\
\hline 14/Mar & 72,50 & 66,98 & 76,81 & $\mathbf{8 2 , 0 3}$ \\
\hline 15/Mar & 71,97 & 70,82 & 74,81 & 77,02 \\
\hline 17/Mar & 73,34 & 70,82 & 77,71 & $\mathbf{7 9 , 7 9}$ \\
\hline 18/Mar & 73,80 & 73,06 & 77,32 & $\mathbf{8 2 , 2 1}$ \\
\hline 20/Mar & 71,25 & 72,30 & 72,99 & $\mathbf{7 3 , 0 5}$ \\
\hline 21/Mar & 69,46 & 67,98 & 69,34 & $\mathbf{7 1 , 9 9}$ \\
\hline 29/Mar & 66,54 & 67,54 & 71,31 & $\mathbf{7 4 , 0 9}$ \\
\hline $\begin{array}{l}\text { Média } \\
\text { Desvio } \\
\text { padrão }\end{array}$ & $32,49^{\text {a }}$ & $70,33^{\text {a }}$ & $77,15^{\text {b }}$ & $80,11^{\text {b }}$ \\
\hline \hline
\end{tabular}

${ }^{\mathrm{a}},{ }^{\mathrm{b}}=$ letras diferentes, na mesma linha (média), ressaltam diferenças estatísticas para $\mathrm{p}<0,05$.

\section{4. Índice de Temperatura Ambiente e Umidade (THI)}

Relativamente ao THI, observa-se (Figura 4.4) que, com exceção de sete dias (24 e 26 de fevereiro e $1^{\circ}, 3,6,15$ e 20 de março), em que os índices verificados nas diferentes instalações foram superiores ao campo, em todos os outros dias os valores de THI a campo foram maiores que nas instalações. Com relação ao estábulo, em seis dias, dentre os setes acima identificados, o THI foi superior ao do campo (24 e 26 de fevereiro e $1^{\circ}, 3,6$ e 15 de março).

As instalações do tie-stall e free-stall apresentaram um índice significativamente $(\mathrm{p}<0,05)$ inferior ao do campo e do estábulo (Tabela 4.6). Entre 
esses dois últimos, porém, não se observou diferença significativa $(\mathrm{p}<0,05)$, embora o valor da média para o campo tenha sido pouco maior que o do estábulo (76,36 e 76,03 respectivamente). Isso reforça a indicação de que o estábulo não é uma alternativa viável para promover o conforto térmico dos animais, mesmo considerando-se a permanência do gado por poucas horas em seu interior.

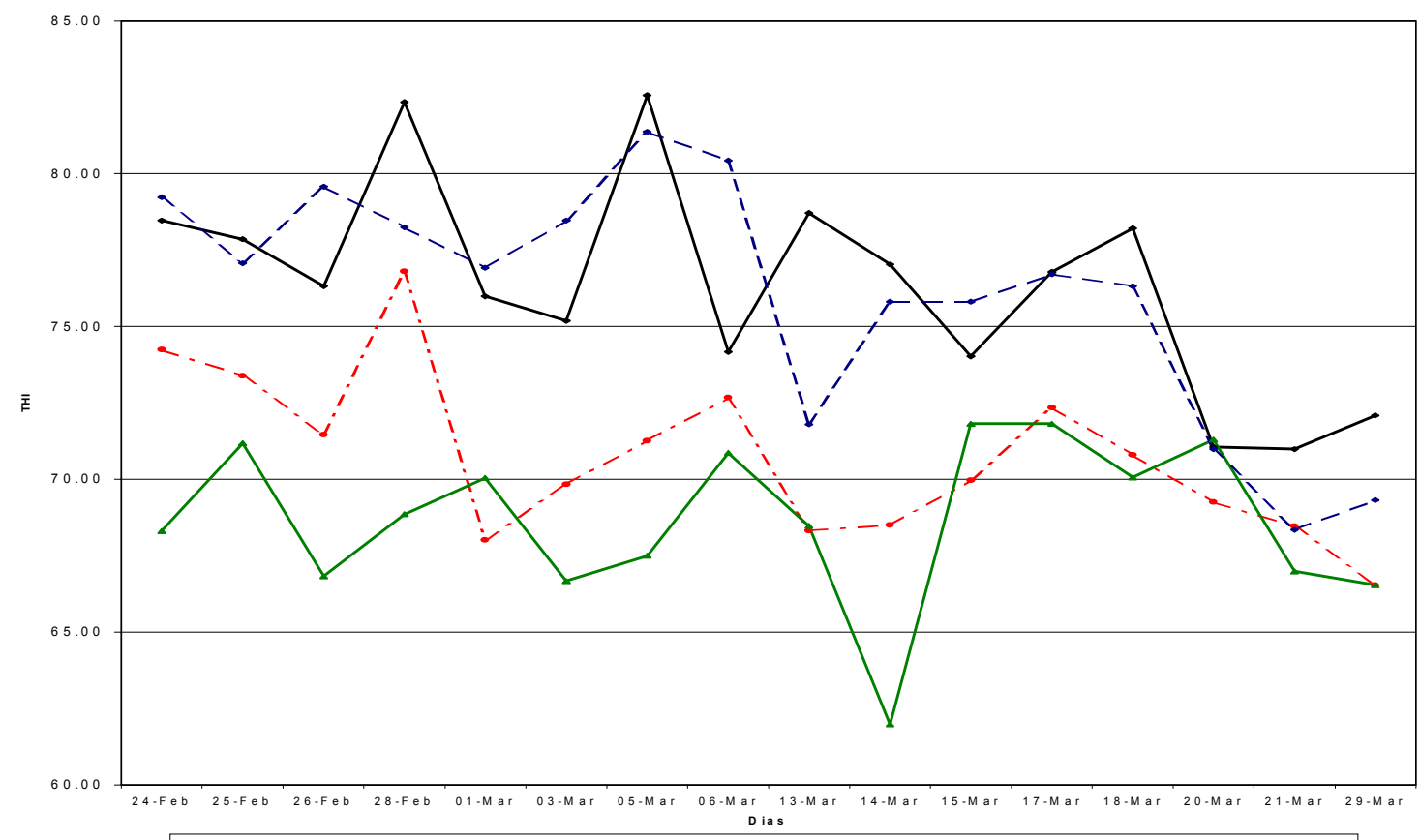

Figura 4.4. Comparação dos valores de THI para os diversos tipos de instalação nos dias críticos.

Em apenas um dia (20 de março), dentre os 16 analisados, verificou-se um THI superior no free-stall comparado com o campo (71,30 e 71,05 respectivamente).

Pode-se observar que, usando como base a Tabela 2.1 do item 2.2.1, o tiestall teve, dentre os 16 dias críticos, apenas cinco dias de estresse ameno para os animais alojados, sendo os outros 11 dias sem estresse.

O free-stall, não teve nenhum dia sob estresse para os animais, apesar de, no dia 20 de março, ter alcançado o maior valor de THI entre as diversas instalações analisadas. 
O estábulo teve dez dias de estresse ameno e três dias de estresse moderado, além de ter alcançado o maior valor de THI em cinco dias.

Desconfortáveis mesmo, foram as condições a campo, que teve 14 dos 16 dias sob estresse para os animais, sendo destes, 12 dias de estresse ameno e dois de estresse moderado.

Do ponto de vista do THI, tanto o tie-stall como o free-stall, funcionam como proteção para a radiação solar. O free-stall se mostrou mais efetivo sob esse aspecto, apesar de não diferir estatisticamente do tie-stall.

Tabela 4.6. Valores de THI nos dias críticos nas diferentes instalações e a campo às $13 \mathrm{~h}$. Em itálico e negrito estão assinalados os maiores valores para o dia.

\begin{tabular}{|c|c|c|c|c|}
\hline DIAS & TIE-STALL & $\begin{array}{l}\text { FREE- } \\
\text { STALL } \\
\end{array}$ & ESTÁBULO & CAMPO \\
\hline $24 / \mathrm{Fev}$ & 74,24 & 68,31 & 79,23 & 78,47 \\
\hline $25 / \mathrm{Fev}$ & 73,39 & 71,18 & 77,07 & 77,85 \\
\hline $26 / \mathrm{Fev}$ & 71,47 & 66,83 & 79,58 & 76,32 \\
\hline $28 / \mathrm{Fev}$ & 76,80 & 68,85 & 78,25 & 82,35 \\
\hline 01/Mar & 68,02 & 70,04 & 76,92 & 75,99 \\
\hline 03/Mar & 69,83 & 66,67 & 78,47 & 75,18 \\
\hline 05/Mar & 71,26 & 67,50 & 81,38 & 82,57 \\
\hline 06/Mar & 72,67 & 70,86 & 80,43 & 74,16 \\
\hline 13/Mar & 68,32 & 68,48 & 71,80 & 78,72 \\
\hline 14/Mar & 68,50 & 61,98 & 75,81 & 77,03 \\
\hline 15/Mar & 69,97 & 71,82 & 75,81 & 74,02 \\
\hline 17/Mar & 72,34 & 71,82 & 76,71 & 76,79 \\
\hline 18/Mar & 70,80 & 70,06 & 76,32 & 78,21 \\
\hline 20/Mar & 69,25 & 71,30 & 70,99 & 71,05 \\
\hline 21/Mar & 68,46 & 66,98 & 68,34 & 70,99 \\
\hline 29/Mar & 66,54 & 66,54 & 69,31 & 72,09 \\
\hline Média & $70,74^{\mathrm{a}}$ & $68,70^{\mathrm{a}}$ & $76,03^{b}$ & $76,36^{\mathrm{b}}$ \\
\hline $\begin{array}{l}\text { Desvio } \\
\text { padrão }\end{array}$ & 2,68 & 2,62 & 3,93 & 3,44 \\
\hline
\end{tabular}




\subsection{Comentários Adicionais}

Conforme explicação feita na introdução do item 4, a escolha do horário das $13 \mathrm{~h}$ deveu-se às suas médias de entalpia ligeiramente superiores às médias das $11 \mathrm{~h}$. Outro fator de fundamental importância foi o fato de, às 11 h, os animais não estarem alojados no estábulo para alimentação e sim soltos no pasto. Portanto, não teria sentido fazer a análise, sob o ponto de vista de conforto térmico, num horário em que a instalação não é utilizada. Talvez um próximo trabalho possa ser realizado às $15 \mathrm{~h}$, na tentativa de se analisar a ocorrência de maior acúmulo de radiação solar em tal horário.

Pela análise da Tabela 4.7, observa-se que, para todos os índices de conforto térmico analisados (entalpia, ITGU, BGHI, e THI), as médias obtidas a campo, às 13 h nos 16 dias críticos, são sempre superiores às médias dos índices no estábulo, embora não exista diferença significativa entre elas $(\mathrm{p}<0,05)$.

Um dos fatores que pode estar diferenciando o desempenho das instalações é a altura do pé-direito. Enquanto nas instalações de tie-stall e free-stall a altura do pédireito é de 3,90 m, no estábulo ela é de 2,90 m, causando assim uma maior dificuldade para a dissipação do calor no interior deste último. Isto ajuda a explicar os piores valores atingidos pelos índices de conforto térmico no estábulo comparativamente com as demais instalações.

Outro fator, que com certeza determina a superioridade do tie-stall e free-stall em temor de proporcionar maior conforto térmico aos animais ali alojados, é justamente o uso de ventiladores e nebulizadores, pois ambos têm a função de reduzirem a temperatura ambiente, sem causar uma elevação da umidade relativa do ar.

Entre as instalações de tie-stall e free-stall, também não existem diferenças significativas $(\mathrm{p}<0,05)$ entre todos os índices de conforto térmico analisados (entalpia ITGU, BGHI e THI), apesar das médias calculadas para o free-stall serem menores do que as calculadas para o tie-stall (Tabela 4.7). 
Tabela 4.7. Valores médios, para cada tipo de instalação, às 13 h, dos índices de conforto analisados.

\begin{tabular}{||c|c|c|c|c||}
\hline \hline TIPO DE COBERTURA & $\begin{array}{c}\text { ENTALPIA } \\
(\mathrm{kJ} / \mathrm{kg} \text { de } \mathrm{ar} \\
\text { seco })\end{array}$ & ITGU & BGHI & THI \\
\hline Tie-stall & $73,88^{\mathrm{a}}$ & $20,87^{\mathrm{a}}$ & $72,49^{\mathrm{a}}$ & $70,74^{\mathrm{a}}$ \\
\hline Free-stall & $70,10^{\mathrm{a}}$ & $19,56^{\mathrm{a}}$ & $70,33^{\mathrm{a}}$ & $68,70^{\mathrm{a}}$ \\
\hline Campo & $86,49^{\mathrm{b}}$ & $25,05^{\mathrm{b}}$ & $80,11^{\mathrm{b}}$ & $76,36^{\mathrm{b}}$ \\
\hline Estábulo & $80,70^{\mathrm{b}}$ & $23,67^{\mathrm{b}}$ & $77,15^{\mathrm{b}}$ & $76,03^{\mathrm{b}}$ \\
\hline \hline
\end{tabular}

${ }^{\mathrm{a}},{ }^{\mathrm{b}}=$ letras diferentes, na mesma coluna, ressaltam diferenças estatísticas para $\mathrm{p}<0,05$.

Entretanto, as médias de campo e de estábulo diferem significativamente $(\mathrm{p}<$ 0,05) das médias obtidas do tie-stall e do free-stall, para todos os 16 dias críticos analisados, no horário das 13 h. O mesmo ocorre para tie-stall e free-stall em relação ao campo, para o horário das $11 \mathrm{~h}$ nos 17 dias críticos correspondentes, conforme ilustrado na Tabela 4.8 .

Tabela 4.8. Valores médios, para cada tipo de instalação, às 11 h, dos índices de conforto analisados.

\begin{tabular}{|c|c|c|c|c||}
\hline \hline TIPO DE COBERTURA & $\begin{array}{c}\text { ENTALPIA } \\
(\mathrm{kJ} / \mathrm{kg} \text { de } \mathrm{ar} \\
\text { seco })\end{array}$ & ITGU & BGHI & THI \\
\hline Tie-stall & $74,58^{\mathrm{a}}$ & $20,71^{\mathrm{a}}$ & $71,15^{\mathrm{a}}$ & $70,09^{\mathrm{a}}$ \\
\hline Free-stall & $73,78^{\mathrm{a}}$ & $20,42^{\mathrm{a}}$ & $70,78^{\mathrm{a}}$ & $69,25^{\mathrm{a}}$ \\
\hline Campo & $84,38^{\mathrm{b}}$ & $24,25^{\mathrm{b}}$ & $77,50^{\mathrm{b}}$ & $74,44^{\mathrm{b}}$ \\
\hline
\end{tabular}

Para todos os índices analisados, as instalações de tie-stall e free-stall se mostraram superiores ao estábulo e campo, relativamente a proporcionar aos animais ali alojados um maior conforto térmico em relação ao ambiente externo. Sendo que o free-stall teve sempre índices ligeiramente inferiores aos obtidos no tie-stall. 


\subsection{Resultados Econômicos}

Para caracterização de cada propriedade a respeito dos seus custos de produção de leite, seguem, na Tabela 4.9, os custos acompanhados no período de um ano.

Os três sistemas de produção de leite têm seus custos superiores aos valores recebidos da cooperativa de laticínios, de modo que a situação de todos os sistemas acompanhados neste estudo de caso, não é confortável em termos de perpetuação na atividade.

Tabela 4.9 Custos de produção de leite tipo "B", em cada sistema de produção comparados com o valor pago pela cooperativa local. Valores em reais (R\$).

\begin{tabular}{|c|c|c|c|c||}
\hline MÊS & $\begin{array}{c}\text { PREÇO DO } \\
\text { LEITE TIPO “B” }\end{array}$ & $\begin{array}{c}\text { CUSTO DO } \\
\text { LEITE TIE- } \\
\text { STALL }\end{array}$ & $\begin{array}{c}\text { CUSTO DO } \\
\text { LEITE FREE- } \\
\text { STALL }\end{array}$ & $\begin{array}{c}\text { CUSTO DO } \\
\text { LEITE PASTEJO } \\
\text { CONTÍNUO }\end{array}$ \\
\hline Mai/99 & 0,35 & 0,81 & 0,55 & 0,40 \\
\hline Jun/99 & 0,36 & 0,82 & 0,55 & 0,43 \\
\hline Jul/99 & 0,36 & 0,82 & 0,56 & 0,43 \\
\hline Ago/99 & 0,37 & 0,83 & 0,56 & 0,42 \\
\hline Set/99 & 0,37 & 0,83 & 0,56 & 0,42 \\
\hline Out/99 & 0,38 & 0,83 & 0,55 & 0,44 \\
\hline Nov/99 & 0,38 & 0,84 & 0,55 & 0,44 \\
\hline Dez/99 & 0,39 & 0,85 & 0,56 & 0,47 \\
\hline Jan/00 & 0,38 & 0,84 & 0,56 & 0,46 \\
\hline Fev/00 & 0,39 & 0,85 & 0,57 & 0,46 \\
\hline Mar/00 & 0,39 & 0,85 & 0,57 & 0,47 \\
\hline Abr/00 & 0,39 & 0,85 & 0,57 & 0,47 \\
\hline \hline
\end{tabular}

Os subitens 4.6.1 a 4.6.3 trazem uma análise mais detalhada de cada sistema de produção, no que diz respeito a seus custos de produção. 


\subsubsection{Caracterização econômica do tie-stall}

Os custos de produção estão muito acima do valor recebido com a venda do leite produzido. Algumas considerações são necessárias.

O objetivo do proprietário não era produzir leite e vendê-lo. O leite era considerado um subproduto da atividade principal, que no caso era produzir uma linhagem genética de altíssimo padrão. Foi empregada inseminação artificial com touros de reconhecido potencial de transmissão genética, para melhora da produção de leite e de tipo (conformação corporal). Realizou-se também produção de embriões com vacas de excelentes linhagens (produção de leite maior que 11 mil litros de leite em 305 dias).

Tais interesses tiveram como conseqüência um alto gasto, no que diz respeito à compra de sêmen caro e alimentação de alto padrão às vacas, constituída de feno de alfafa, silagem de milho e ração com alta energia. Além disso, incluem-se os altos custos envolvidos com a transferência de embriões.

A Tabela 4.10 ilustra o detalhamento dos custos de produção de leite. Os elevados custos operacionais efetivos demonstram inviabilidade produtiva no curto prazo. 
Tabela 4.10 Custos detalhados de produção de leite tipo "B", no sistema tie-stall, em relação ao valor pago pela cooperativa local. Valores em reais $(\mathrm{R} \$)$.

\begin{tabular}{||c|c|c|c|c||}
\hline \hline MÊS & $\begin{array}{c}\text { PREÇO DO } \\
\text { LEITE TIPO “B” }\end{array}$ & $\begin{array}{c}\text { CUSTO } \\
\text { OPERACIONAL } \\
\text { EFETIVO }\end{array}$ & $\begin{array}{c}\text { CUSTO } \\
\text { OPERACIONAL } \\
\text { TOTAL }\end{array}$ & $\begin{array}{c}\text { CUSTO } \\
\text { TOTAL }\end{array}$ \\
\hline Mai/99 & 0,35 & 0,81 & 0,88 & 0,98 \\
\hline Jun/99 & 0,36 & 0,82 & 0,88 & 0,98 \\
\hline Jul/99 & 0,36 & 0,82 & 0,89 & 0,99 \\
\hline Ago/99 & 0,37 & 0,83 & 0,89 & 0,99 \\
\hline Set/99 & 0,37 & 0,83 & 0,89 & 0,99 \\
\hline Out/99 & 0,38 & 0,83 & 0,90 & 1,00 \\
\hline Nov/99 & 0,38 & 0,84 & 0,90 & 1,00 \\
\hline Dez/99 & 0,39 & 0,85 & 0,90 & 1,00 \\
\hline Jan/00 & 0,38 & 0,84 & 0,89 & 0,99 \\
\hline Fev/00 & 0,39 & 0,85 & 0,89 & 0,99 \\
\hline Mar/00 & 0,39 & 0,85 & 0,91 & 1,01 \\
\hline Abr/00 & 0,39 & 0,85 & 1,01 \\
\hline \hline
\end{tabular}

\subsubsection{Caracterização econômica do free-stall}

Novamente neste sistema de produção de leite analisado no presente estudo de caso, os custos de produção de leite estão superiores aos valores recebidos na venda (Tabela 4.11).

As explicações descritas no item 4.6.1 são também, em parte, responsáveis por essa ocorrência. Além disso, as vacas do tie-stall em estágio de lactação mais avançado, conforme surge necessidade de espaço, passam para o free-stall até secarem, o que acarreta um aumento do custo de produção deste último.

Ocorre, também, a incapacidade de sobrevivência, quanto à viabilidade econômica da atividade leiteira, mantidas as condições atuais de custos produtivos, especialmente no médio e longo prazo. 
Tabela 4.11. Custos detalhados de produção de leite tipo "B", no sistema free-stall, em relação ao valor pago pela cooperativa local. Valores em reais (R\$).

\begin{tabular}{||c|c|c|c|c||}
\hline \hline MÊS & $\begin{array}{c}\text { PREÇO DO } \\
\text { LEITE TIPO } \\
\text { "B" }\end{array}$ & $\begin{array}{c}\text { CUSTO } \\
\text { OPERACIONAL } \\
\text { EFETIVO }\end{array}$ & $\begin{array}{c}\text { CUSTO } \\
\text { OPERACIONAL } \\
\text { TOTAL }\end{array}$ & CUSTO TOTAL \\
\hline Mai/99 & 0,35 & 0,41 & 0,48 & 0,55 \\
\hline Jun/99 & 0,36 & 0,42 & 0,49 & 0,56 \\
\hline Jul/99 & 0,36 & 0,42 & 0,49 & 0,56 \\
\hline Ago/99 & 0,37 & 0,42 & 0,49 & 0,56 \\
\hline Set/99 & 0,37 & 0,43 & 0,50 & 0,57 \\
\hline Out/99 & 0,38 & 0,44 & 0,51 & 0,58 \\
\hline Nov/99 & 0,38 & 0,44 & 0,51 & 0,58 \\
\hline Dez/99 & 0,39 & 0,45 & 0,52 & 0,59 \\
\hline Jan/00 & 0,38 & 0,44 & 0,51 & 0,58 \\
\hline Fev/00 & 0,39 & 0,44 & 0,52 & 0,59 \\
\hline Mar/00 & 0,39 & 0,45 & 0,52 & 0,59 \\
\hline Abr/00 & 0,39 & 0,45 & 0,52 & 0,59 \\
\hline \hline
\end{tabular}

\subsubsection{Caracterização econômica do pastejo contínuo}

Neste sistema, o custo operacional efetivo é inferior ao valor recebido com a venda do leite, o que faz com que, momentaneamente, haja condições do produtor permanecer na atividade leiteira. A receita supera, mês a mês, o desembolso direto efetuado com a atividade e conseqüentemente o produtor, no final do mês, não necessita realizar desembolsos em dinheiro para manter a atividade (Tabela 4.12).

Com exceção de dois meses (junho e julho/99), em que o custo operacional total é superior ao valor recebido pela venda de leite; e de um mês (maio/99), em que o custo operacional total é inferior ao valor recebido com a venda de leite, em todos os outros nove meses, este custo é igual ao valor recebido com a venda do leite. 
Isto significa que o produtor tem receita superior ao desembolso para manter a atividade ativa. Ele é remunerado pela sua atividade e ainda quanto aos custos relativos à depreciação. Se o produtor não tem lucratividade com a atividade, pelo menos não ocorre um prejuízo, e ele terá condições de repor benfeitorias, pastagens e animais adultos, como explicado no item 4.6.1.

Como o custo total é sempre superior ao valor recebido, significa que o seu capital não é remunerado pela atividade, além de não ter como remunerar a terra. No médio e longo prazo, o produtor terá condição de continuar a atividade. Porém, mantida a atual condição, não será possível obter retorno financeiro positivo.

Tabela 4.12 Custos detalhados de produção de leite tipo "B", no sistema de pastejo contínuo, em relação ao valor pago pela cooperativa local. Valores em reais (R\$).

\begin{tabular}{||c|c|c|c|c||}
\hline MÊS & $\begin{array}{c}\text { PREÇO DO } \\
\text { LEITE TIPO “B” }\end{array}$ & $\begin{array}{c}\text { CUSTO } \\
\text { OPERACIONAL } \\
\text { EFETIVO }\end{array}$ & $\begin{array}{c}\text { CUSTO } \\
\text { OPERACIONAL } \\
\text { TOTAL }\end{array}$ & $\begin{array}{c}\text { CUSTO } \\
\text { TOTAL }\end{array}$ \\
\hline Mai/99 & 0,35 & 0,32 & 0,34 & 0,40 \\
\hline Jun/99 & 0,36 & 0,35 & 0,37 & 0,43 \\
\hline Jul/99 & 0,36 & 0,38 & 0,40 & 0,46 \\
\hline Ago/99 & 0,37 & 0,35 & 0,37 & 0,43 \\
\hline Set/99 & 0,37 & 0,35 & 0,37 & 0,43 \\
\hline Out/99 & 0,38 & 0,36 & 0,38 & 0,44 \\
\hline Nov/99 & 0,38 & 0,36 & 0,38 & 0,44 \\
\hline Dez/99 & 0,39 & 0,37 & 0,39 & 0,47 \\
\hline Jan/00 & 0,38 & 0,36 & 0,38 & 0,44 \\
\hline Fev/00 & 0,39 & 0,37 & 0,39 & 0,47 \\
\hline Mar/00 & 0,39 & 0,37 & 0,39 & 0,47 \\
\hline Abr/00 & 0,39 & 0,37 & 0,39 & 0,47 \\
\hline \hline
\end{tabular}




\section{CONCLUSÕES}

Com base neste estudo de caso de três sistemas de produção de leite Tipo "B" analisados, com vacas em lactação da raça Holandesa, variedade Preta e Branca, na região de São José dos Campos, SP, pode-se concluir que:

- A instrumentação de monitoramento, os horários de coleta de registro das variáveis climáticas, bem como a escolha dos dias críticos e dos índices de conforto térmico, mostraram-se adequados para análise do conforto térmico nas instalações da atividade leiteira em pauta.

- Os índices de conforto térmico escolhidos (entalpia, índice de temperatura de globo e umidade - ITGU, índice de globo negro e umidade - BGHI, índice de temperatura ambiente e umidade - THI), foram eficazes na diferenciação das condições de conforto ambiental entre as instalações analisadas em relação às condições exteriores.

- Os índices de conforto térmico (entalpia, ITGU, BGHI e THI) obtidos demonstram que as instalações de free-stall e tie-stall são superiores, em termos de proporcionarem conforto térmico aos animais alojados, em relação ao estábulo convencional ou se estivessem a campo.

- Apesar dos índices de conforto térmico obtidos no estábulo terem sido menores do que os obtidos a campo, não se observou diferença significativa entre ambos. 
- Neste presente estudo de caso, verificou-se que, no momento do experimento, o Custo Total do leite tipo B, em cada um dos sistemas de produção de leite analisados, foi sempre superior ao preço pago pela Cooperativa Total. 


\section{REFERÊNCIAS BIBLIOGRÁFICAS}

ALVES, E. Leite: o que determina os custos. Revista Balde Branco, São Paulo, v.35, n.411, p. 38-40, jan.1999.

ARCARO JÚNIOR, I., Avaliação da influência de ventilação e aspersão em coberturas de sombrite para vacas em lactação. Campinas, 2000. 93p. Tese (Doutorado) - FEAGRI, Universidade Estadual de Campinas.

BAETA, F.C. et al. Equivalent temperature index at temperatures above the thermo neutral for lactating dairy cows. St. Joseph, MI-USA: ASAE, 1987. 21p. /Paper n.87-4015/.

BAETA, F. C.; SOUZA, C.F. Ambiência em edificações rurais - conforto animal. Viçosa: UFV, 1997. 246 p.

BACCARI, F.JR. Adaptação de sistemas de manejo na produção de leite em clima quente. Produção de Leite. In: SIMPÓSIO BRASILEIRO DE AMBIÊNCIA NA PRODUÇÃO DE LEITE, 1., Piracicaba, 1998. Anais. Piracicaba, FEALQ, 1998a. p. 10-23.

BACCARI, F.JR. Manejo ambiental de leite em climas quentes. In: CONGRESSO BRASILEIRO DE BIOMETEOROLOGIA, GOIÂNIA, 1998. Anais. Goiânia: SBBiomet, 1998b. p. 136-161.

BEDFORD, T.; WARNER, C.G. The globe temperature in studies of heating and ventilation. Industrial Health Research Board,. 7p. 1934. 
BIAGI, J.D. \& SILVA, I.J.O. Software para determinar as propriedades psicrométricas do ar. In: XIX Congresso Brasileiro de Engenharia Agrícola, Piracicaba, 1990. Anais. Piracicaba,USP, 1990. P. 1161-1175.

BOND, T.E. Solar atmospheric and terrestral radiation received by shaded and unshaded animals. Transactions of the ASAE (Am.Soc. Agric.Eng)., v.10, p.622-627, 1971

BOND, T.E.; KELLY, C.F. The globe thermometer in agricultural research. Transactions of the ASAE, v.36, n.7, p.251-255, 1955.

BUFFINGTON, D.E. Black globe-humidity confort index for dairy cows. In: WINTER MEETING OF THE AMERICAN SOCIETY OF AGRICULTURAL ENGINEERS, St Joseph, 1977. Trans ASAE (Am.Soc. Agric.Eng), 1977 p. 4517.

CAMARGO, A.C.de. Confinamento em "free-stall”. In: CONFINAMENTO DE BOVINOS LEITEIROS, 1., Piracicaba, 1991. Anais. Piracicaba: FEALQ, 1991. p. 01-28.

COSTA, E.C. Arquitetura ecológica: condicionamento térmico natural. São Paulo, Ed. Edgard Blücher,. 265p. 1982.

ESMAY, M. L. Principles of animal environment. West Port, C.T. Avi Publishing, 1979. 325p.

GHELFI FILHO, H., et al. Índice de conforto térmico e da CTR para diferentes, materiais de cobertura em 3 estações do ano. In: CONGRESSO BRASILEIRO DE ENGENHARIA AGRÍCOLA, Lavras. 1993. Anais. Lavras. 1993. P. 94-113. 
GITMAN, L.J. Princípios de administração financeira. São Paulo: Habra, 1997. 840 p.

GOMES, A.T. et al. Análise técnico-econômica de sistemas de produção de leite. In: PRODUÇÃO LEITEIRA: PROBLEMAS E SOLUÇÕES,1., São Paulo, 1985. Anais. São Paulo: Fundação Cargill, 1985. p. 59-82.

GOMES, S.T. Ajustamento na produção de leite. Folha de São Paulo, São Paulo, 17 fev. 1998. Agrofolha, p. 4.

GOMES, S.T. Indicadores de eficiência técnica e econômica na produção de leite. São Paulo: Milk Bizz, 1997. 178 p.

HOFFMANN, R, ENGLER, J,J, DE C., SERRANO, O THAME, A.C. DE M., NEVES, E. M. Administração da Empresa Agrícola. 5. ed. São Pulo, Pioneira, 1987. $235 \mathrm{p}$.

HUBER, J. T. Alimentação de vacas de alta produção sob condições de stress térmico. In: BOVINOCULTURA LEITEIRA, Piracicaba: FEALQ, 1990. p. 3348.

HUTCHINSON, L, Animal environments and health. Veterinary Science, 1999, v. 26, p. $70-78$

IGONO, M.O., BJTVEDT, G., SANFORD - CRANE, H.T. Environmental profile and critical temperature effects on milk production of Holsteins cows in desert climate. Int. J. Biometeor, 1992. v.36, p. 77-87.

JANK, F.S. A importância da administração profissional da produção agropecuária. Revista Preços Agrícolas. Novembro 1997. p. 3-6. 
JANK, F.S. Gestão da pecuária leiteira sob medida para o Brasil. Revista Agroanalysis, v.18, n.6, p. 20-23, junho 1998.

JANK, M.S.; FARINA, E.M.M.Q.; GALAN, V.B. O agribusiness do leite no Brasil. São Paulo: Milkbiz, 1999. 100 p.

JOHNSON, H.D. Environmetal management of cattle to minimize the stress of climatic change. Int. J. Biometeor. 1980. V24, p. 65-78.

LALONI, L.A. Correção do índice de temperatura equivalente (ETI) para gado leiteiro em regime semi-estabulado. Campinas, 1996. 35p. Dissertação (Mestrado) - FEAGRI, Universidade Estadual de Campinas.

LOPES, M. A. et al. Custo Leite para Windows: Software de Controle de Custos para a Pecuária Leiteira. In: Revista Brasileira de Zootecnia. Vol 29(5). P. 15041510. 2000.

LOPES, M. A., LOPES, D DE C.F. Desenvolvimento de um sistema computacional para cálculo do custo de produção do leite. Revista Brasileira Agroinformártica, 2(1): 1-12. 1999

MACHADO, P. F. Efeito da temperatura sobre a produção, Reprodução e Sanidade de Bovinos Leiteiros. In: SIMPÓSIO BRASILEIRO DE AMBIÊNCIA NA PRODUÇÃO DE LEITE, 1., Piracicaba, 1998. Anais. Piracicaba, FEALQ, 1998a. p. 179-188.

MATSUNAGA, N et al. Metodologia de custo de produção utilizado pelo IEA. São Paulo, SP: IEA, 1976. p. 123-139. n. 2.

MATTOS, W.R.S. Confinamento de bovinos leiteiros. In: Produção de Leite: conceitos básicos. São Paulo: Fealq, 1988. p. 81-86. 
MATTOS, Z.P.B.S. Contabilidade e contabilidade Rural. Revista Preços Agrícolas. Março de 1997. p. 18-21.

MORGAN, W.E. Heat reflective roof coatings. St. Joseph: ASAE, 1990. p.9. /ASAE paper $904513 /$.

MOURA, D.J., NÄÄS, I.A. Estudo comparativo de índices de conforto térmico na produção animal. In: CONGRESSO BRASILEIRO DE ENGENHARIA AGRÍCOLA, Lavras. 1993. Anais. Lavras. 1993. P. 42-46.

NÄÄS, I.A. Princípios de conforto térmico na produção animal. São Paulo: Ícone, 1989. 183 p.

NÄÄS, I.A.; MOURA, D.J.; LAGANÁ, C.A. A amplitude térmica e seu reflexo na produtividade de frangos de corte. In: CONFERÊNCIA APINCO DE CIÊNCIA E TECNOLOGIA AVÍCOLAS, 1., Curitiba, 1995. Anais. Campinas: Facta, 1995. p. 203-204.

NÄÄS, I.A. Biometeorologia e construções rurais em ambiente tropical. In: CONGRESSO BRASILEIRO DE BIOMETEOROLOGIA, 2., Goiânia, 1998. Anais. Goiânia, SBBiomet, 1998. p. 63-73.

NÄÄS, I.A. O valor do conforto animal. Revista Pesquisa FAPESP. Novembro de 1999. p. 30-33.

NGUYEN H.T. Planejamento e controle financeiro das empresas agropecuárias. São Paulo: Edições Universidade-Empresa, 1990. 382 p.

NICOLAU, N. M. O problema do leite é o preço. Folha de São Paulo, São Paulo, 24 mar. 1998. Agrofolha, p. 4. 
NORONHA, J.F. Projetos agropecuários. São Paulo: Atlas, 1988. 269 p.

OLIVEIRA, P.A.V. et al. Efeito do tipo de telha sobre o acondicionamento ambiental e o desempenho de frangos de corte. In: CONFERÊNCIA APINCO DE CIÊNCIA TECNOLOGIA AVÍCOLAS, 1., Curitiba, 1995. Anais. Campinas: Facta, 1995. p. 297-8.

PIRES, M.F.A. Reflexos do Estresse Térmico no comportamento das Vacas em Lactação. In: SIMPÓSIO BRASILEIRO DE AMBIÊNCIA NA PRODUÇÃO DE LEITE, 1., Piracicaba, 1998. Anais. Piracicaba, FEALQ, 1998. p. 68-102.

REIS, D.L. dos. Estudo técnico e econômico da propriedade rural. Informe Agropecuário, 12 (143): 23-38. 1986

REVISTA BALDE BRANCO. São Paulo: CLESP, v.35, n.414, 1999a, p. 63.

REVISTA BALDE BRANCO. São Paulo: CLESP, v.35, n.413, 1999b, p. 42.

RIBEIRO, S.A.; SAVASTANO JR., H., ABLAS, D. DE S. Avaliação do desempenho operacional e econômico de máquinas para fenação. I. Cultura de costa-cross Boletim da Indústria Animal, v.56, n.2, p. 147-151, 1997.

ROMERO, C. Subsídios aumentam 400\% nos EUA. Valor Econômico, São Paulo, 23 mai. 2001. p.A12.

ROSENBERG, L.J., BIAD, B.L., VERNS, S.B. Human and animal biometeorology. In: Microclimate-the biological environment, 2.ed. New York: WileyInterscience, 1983, Cha.12, p.425-467. 
SAVASTANO JR., H.; DA SILVA, I.J.O.; LUZ, P.H.C.; FARIA, D.E. Desempenho de alguns sistemas de cobertura para aviários. Engenharia Rural, v.8, n.1, p. 111, 1997.

SAVASTANO JR., H.; SILVA, A.F; BARBALHO, R.L.C. Considerações a respeito da estrutura de custos de produção de leite tipo B: análise da região de Descalvado/SP. In: REUNIÃO DA SOCIEDADE DE ZOOTECNIA, 32. Brasília, 1995. Anais. Brasília: SBZ, 1995. p. 605-7.

SEMINÁRIO SOBRE METODOLOGIAS DE CÁLCULO DO CUSTO DE PRODUÇÃO DE LEITE, 1., Piracicaba, Anais. Piracicaba: CEPEA, 1999. 40 p.

SEVEGNANI, K.B. Avaliação de tinta cerâmica em telhados de modelos em escala reduzida, simulando galpões para frangos de corte. Campinas, 1997. 64p. Dissertação (Mestrado) - Faculdade de Engenharia Agrícola, Universidade Estadual de Campinas.

SILVA, I.J.O. Climatização das instalações para bovino leiteiro. In: SIMPÓSIO BRASILEIRO DE AMBIÊNCIA NA PRODUÇÃO DE LEITE, 1., Piracicaba, 1998. Anais. Piracicaba, FEALQ, 1998. p. 10-23.

TITTO, E. L. Clima: Influência na Produção de Leite. In : SIMPÓSIO BRASILEIRO DE AMBIÊNCIA NA PRODUÇÃO DE LEITE, 1., Piracicaba, 1998. Anais. Piracicaba, FEAL Q, 1998. p. 10-23. 


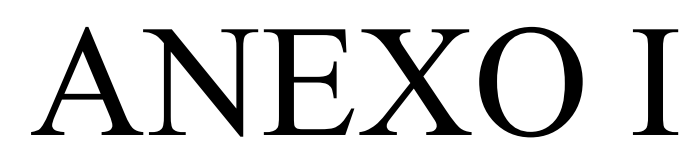

Dados ambientais: coletas diárias 


\begin{tabular}{|c|c|c|c|c|c|c|c|c|c|c|}
\hline Dias & $\begin{array}{c}\text { Temp. } \\
\text { máx }\left({ }^{\circ} \mathrm{C}\right)\end{array}$ & $\begin{array}{c}\text { Temp. } \\
\text { Mín }\left({ }^{\circ} \mathrm{C}\right)\end{array}$ & \begin{tabular}{|c|} 
UR/Temp \\
$7 \mathrm{~h}\left(\% /{ }^{\circ} \mathrm{C}\right)$
\end{tabular} & \begin{tabular}{|l|} 
UR/Temp1 \\
$1 \mathrm{~h}\left(\% /{ }^{\circ} \mathrm{C}\right)$
\end{tabular} & $\begin{array}{c}\text { UR/Temp } \\
13 \mathrm{~h}\left(\% /{ }^{\circ} \mathrm{C}\right)\end{array}$ & $\begin{array}{c}\text { UR/Temp } 17 \\
\text { h }\left(\% /{ }^{\circ} \mathrm{C}\right)\end{array}$ & $\begin{array}{c}\text { TGN } 7 \mathrm{~h} \\
\left({ }^{\circ} \mathrm{C}\right)\end{array}$ & $\begin{array}{c}\text { TGN } 11 \mathrm{~h} \\
\left({ }^{\circ} \mathrm{C}\right)\end{array}$ & $\begin{array}{c}\text { TGN } 13 \mathrm{~h} \\
\left({ }^{\circ} \mathrm{C}\right)\end{array}$ & $\begin{array}{c}\text { TGN } 17 \mathrm{~h} \\
\left({ }^{\circ} \mathrm{C}\right)\end{array}$ \\
\hline $18 /$ fev $/ 00$ & 27,00 & 22,00 & $100 / 17$ & $67 / 23$ & $73 / 22$ & $71 / 20$ & 18 & 34 & 28 & 24 \\
\hline $20 / \mathrm{fev} / 00$ & 27,00 & 21,00 & $74 / 21$ & $69 / 22$ & $62 / 23$ & $60 / 22$ & 23 & 26 & 29 & 27 \\
\hline $21 / \mathrm{fev} / 00$ & 29,00 & 22,00 & 99/19 & $96 / 22$ & $64 / 23$ & $46 / 27$ & 20 & 24 & 26 & 31 \\
\hline $22 / \mathrm{fev} / 00$ & 31,00 & 23,00 & $100 / 17$ & $68 / 21$ & $51 / 22$ & $54 / 24$ & 18 & 34 & 36 & 34 \\
\hline $24 / \mathrm{fev} / 00$ & 32,00 & 23,00 & $100 / 20$ & $62 / 28$ & $53 / 30$ & $100 / 20$ & 20 & 29 & 34 & 21 \\
\hline $25 / \mathrm{fev} / 00$ & 32,00 & 22,00 & $100 / 19$ & $76 / 25$ & $60 / 29$ & $67 / 24$ & 20 & 27 & 33 & 26 \\
\hline $26 / \mathrm{fev} / 00$ & 32,00 & 21,00 & $95 / 21$ & $66 / 27$ & $58 / 28$ & $60 / 26$ & 23 & 36 & 35 & 33 \\
\hline $27 / \mathrm{fev} / 00$ & 33,00 & 22,00 & $97 / 21$ & $67 / 26$ & $51 / 28$ & $100 / 20$ & 23 & 29 & 34 & 21 \\
\hline $28 / \mathrm{fev} / 00$ & 33,00 & 22,00 & $100 / 20$ & $66 / 25$ & $52 / 33$ & $72 / 22$ & 29 & 26 & 34 & 24 \\
\hline $29 / \mathrm{fev} / 00$ & 32,00 & 21,00 & $99 / 20$ & $62 / 29$ & $60 / 23$ & $62 / 24$ & 23 & 33 & 29 & 30 \\
\hline $01 / \mathrm{mar} / 00$ & 32 & 21 & $96 / 19$ & $60 / 24$ & $69 / 27$ & $62 / 26$ & 19 & 31 & 37 & 29 \\
\hline $03 / \mathrm{mar} / 00$ & 32 & 22 & $91 / 20$ & $82 / 27$ & $60 / 27$ & $53 / 28$ & 22 & 29 & 32 & 33 \\
\hline $04 / \mathrm{mar} / 00$ & 33 & 23 & $99 / 20$ & $58 / 22$ & $58 / 27$ & $55 / 29$ & 19 & 29 & 32 & 33 \\
\hline $05 / \mathrm{mar} / 00$ & 33 & 22 & $92 / 20$ & $61 / 33$ & $43 / 34$ & $42 / 34$ & 22 & 34 & 38 & 37 \\
\hline $06 / \mathrm{mar} / 00$ & 33 & 22 & $95 / 21$ & $82 / 24$ & $80 / 25$ & $62 / 27$ & 22 & 28 & 30 & 34 \\
\hline $07 / \mathrm{mar} / 00$ & 32 & 23 & $98 / 21$ & $94 / 23$ & $89 / 22$ & $100 / 20$ & 21 & 24 & 23 & 20 \\
\hline $08 / \mathrm{mar} / 00$ & 30 & 21 & $96 / 19$ & $90 / 20$ & $80 / 22$ & $79 / 20$ & 20 & 22 & 23 & 22 \\
\hline $09 / \mathrm{mar} / 00$ & 29 & 21 & $100 / 19$ & $64 / 22$ & & & 21 & 26 & & \\
\hline $10 / \mathrm{mar} / 00$ & 29 & 20 & $76 / 19$ & $70 / 22$ & $62 / 25$ & $76 / 23$ & 22 & 4 & 33 & 29 \\
\hline $11 / \mathrm{mar} / 00$ & 28 & 22 & $100 / 19$ & $95 / 22$ & $99 / 20$ & $97 / 20$ & 20 & 23 & 22 & 21 \\
\hline $12 / \mathrm{mar} / 00$ & 29 & 20 & $92 / 19$ & $78 / 21$ & $71 / 24$ & $69 / 22$ & 21 & 23 & 26 & 24 \\
\hline $13 / \mathrm{mar} / 00$ & 27 & 21 & $99 / 18$ & $90 / 21$ & $87 / 27$ & $86 / 31$ & 20 & 22 & 28 & 32 \\
\hline $14 / \mathrm{mar} / 00$ & 28 & 22 & $97 / 18$ & $64 / 24$ & $52 / 29$ & $62 / 24$ & 19 & 32 & 34 & 28 \\
\hline $15 / \mathrm{mar} / 00$ & 29 & 22 & $92 / 19$ & $81 / 21$ & $78 / 25$ & $71 / 24$ & 21 & 27 & 28 & 30 \\
\hline $17 / \mathrm{mar} / 00$ & 29 & 19 & $100 / 20$ & $96 / 22$ & $99 / 26$ & $80 / 23$ & 22 & 24 & 29 & 28 \\
\hline $18 / \mathrm{mar} / 00$ & 29 & 19 & $100 / 21$ & $91 / 26$ & $100 / 27$ & $97 / 27$ & 22 & 28 & 31 & 30 \\
\hline $19 / \mathrm{mar} / 00$ & 29 & 22 & $96 / 20$ & $97 / 20$ & $100 / 20$ & $96 / 20$ & 22 & 23 & 21 & 21 \\
\hline $20 / \mathrm{mar} / 00$ & 27 & 21 & $100 / 20$ & $96 / 21$ & $94 / 22$ & $99 / 19$ & 21 & 22 & 24 & 22 \\
\hline $21 / \mathrm{mar} / 00$ & 27 & 19 & $100 / 19$ & $89 / 23$ & $93 / 22$ & $100 / 20$ & 18 & 25 & 23 & 22 \\
\hline $22 / \mathrm{mar} / 00$ & 27 & 19 & $100 / 19$ & $97 / 23$ & $68 / 24$ & $97 / 22$ & 19 & 27 & 32 & 25 \\
\hline $24 / \mathrm{mar} / 00$ & 29 & 20 & $93 / 22$ & $66 / 27$ & $61 / 25$ & $60 / 22$ & 24 & 30 & 27 & 24 \\
\hline $29 / \mathrm{mar} / 00$ & 29 & 20 & $100 / 18$ & $91 / 22$ & $89 / 23$ & $91 / 21$ & 20 & 24 & 25 & 24 \\
\hline $31 / \mathrm{mar} / 00$ & 29 & 20 & $100 / 18$ & $87 / 21$ & $85 / 22$ & $81 / 22$ & 19 & 22 & 24 & 25 \\
\hline
\end{tabular}


Fazenda Santa Terezinha Medidas de Temperatura e Umidade Relativa

Free-stall

\begin{tabular}{|c|c|c|c|c|c|c|c|c|c|c|}
\hline Dias & \begin{tabular}{|c|} 
Temp. \\
máx $\left({ }^{\circ} \mathrm{C}\right)$ \\
\end{tabular} & \begin{tabular}{|c|} 
Temp. \\
Mín $\left({ }^{\circ} \mathrm{C}\right)$ \\
\end{tabular} & \begin{tabular}{|c|} 
UR/Temp 7 h \\
$\left(\% /{ }^{\circ} \mathrm{C}\right)$ \\
\end{tabular} & \begin{tabular}{|c|} 
UR/Temp11 h \\
$\left(\% /{ }^{\circ} \mathrm{C}\right)$
\end{tabular} & \begin{tabular}{|c|}
$\begin{array}{c}\text { UR/Temp 13 h } \\
\left(\% /{ }^{\circ} \mathrm{C}\right)\end{array}$ \\
\end{tabular} & \begin{tabular}{|c|}
$\begin{array}{c}\text { UR/Temp } 17 \mathrm{~h} \\
\left(\% /{ }^{\circ} \mathrm{C}\right)\end{array}$ \\
\end{tabular} & \begin{tabular}{|c|} 
TGN 7h \\
$\left({ }^{\circ} \mathrm{C}\right)$ \\
\end{tabular} & \begin{tabular}{|c|} 
TGN $11 \mathrm{~h}$ \\
$\left({ }^{\circ} \mathrm{C}\right)$ \\
\end{tabular} & \begin{tabular}{|c|} 
TGN $13 \mathrm{~h}$ \\
$\left({ }^{\circ} \mathrm{C}\right)$ \\
\end{tabular} & \begin{tabular}{|c|} 
TGN $17 \mathrm{~h}$ \\
$\left({ }^{\circ} \mathrm{C}\right)$ \\
\end{tabular} \\
\hline $17 / \mathrm{jan} / 00$ & 41,0 & 24,0 & $83 / 28$ & & \begin{tabular}{|r}
$53 / 31$ \\
\end{tabular} & \begin{tabular}{|l}
$64 / 27$ \\
\end{tabular} & & & & \\
\hline $18 / \mathrm{jan} / 00$ & 29,0 & 23,0 & $93 / 23$ & & $64 / 30$ & & 23,0 & & & 31,0 \\
\hline $19 / \mathrm{jan} / 00$ & 29,0 & 23,0 & $97 / 23$ & $94 / 24$ & $87 / 25$ & $95 / 23$ & 22,4 & 24,2 & 24,3 & 23,0 \\
\hline $21 / \mathrm{jan} / 00$ & 28,0 & 20,0 & $93 / 20$ & $87 / 20$ & $70 / 23$ & $72 / 24$ & 20,0 & 21,0 & 24,0 & 24,0 \\
\hline $22 / \mathrm{jan} / 00$ & 32,0 & 19,0 & $98 / 20$ & $60 / 20$ & $58 / 31$ & $54 / 30$ & 21,0 & 22,0 & 31,0 & 30,0 \\
\hline 23/jan/00 & 22,0 & 19,0 & $90 / 19$ & $60 / 20$ & $55 / 21$ & $52 / 20$ & 19,0 & 20,0 & 21,0 & 20,0 \\
\hline $24 / \mathrm{jan} / 00$ & 31,0 & 21,0 & $97 / 20$ & $73 / 23$ & $67 / 27$ & $71 / 25$ & 20,0 & 23,0 & 27,0 & 26,0 \\
\hline 26/jan/00 & 30,0 & 22,0 & $99 / 22$ & $80 / 23$ & $99 / 22$ & $99 / 21$ & 22,0 & 23,6 & 22,6 & 22,0 \\
\hline $27 / \mathrm{jan} / 00$ & 33,0 & 21,0 & $99 / 22$ & $90 / 23$ & $98 / 22$ & $99 / 21$ & 22,0 & 23,0 & 22,0 & 21,0 \\
\hline $28 / \mathrm{jan} / 00$ & 30,0 & 21,0 & $95 / 18$ & $60 / 22$ & $68 / 22$ & $64 / 20$ & 18,2 & 23,0 & 22,0 & 20,0 \\
\hline 29/jan/00 & 29,0 & 20,0 & $99 / 19$ & $74 / 22$ & $61 / 25$ & $73 / 23$ & 19,2 & 22,8 & 26,0 & 24,0 \\
\hline $30 / \mathrm{jan} / 00$ & 25,0 & 21,0 & $99 / 19$ & $75 / 21$ & $74 / 22$ & $72 / 23$ & 19,8 & 21,4 & 22,6 & 23,6 \\
\hline $31 / \mathrm{jan} / 00$ & 32,0 & 20,0 & $97 / 21$ & $79 / 22$ & $80 / 23$ & $99 / 20$ & 21,0 & 22,0 & 23,6 & 24,2 \\
\hline $01 / \mathrm{fev} / 00$ & 29,0 & 19,0 & $95 / 21$ & & $70 / 22$ & $80 / 22$ & 21,00 & 22,40 & 22,40 & 23,00 \\
\hline $02 / \mathrm{fev} / 00$ & 29,0 & 18,0 & $99 / 21$ & $76 / 25$ & $64 / 26$ & $74 / 23$ & 21,00 & 26,00 & 27,00 & 23,00 \\
\hline $03 / \mathrm{fev} / 00$ & 29,0 & 18,0 & $100 / 21$ & $78 / 24$ & $66 / 26$ & $75 / 23$ & 21,20 & 23,00 & 26,00 & 24,00 \\
\hline $04 / \mathrm{fev} / 00$ & 31,0 & 19,0 & $100 / 20$ & $100 / 23$ & $58 / 26$ & $54 / 27$ & 29,00 & 30,00 & 31,00 & 30,00 \\
\hline $05 / \mathrm{fev} / 00$ & 31,0 & 20,0 & $100 / 22$ & $78 / 25$ & $64 / 26$ & $71 / 24$ & 22,00 & 25,00 & 26,00 & 26,80 \\
\hline $06 / \mathrm{fev} / 00$ & 31,0 & 21,0 & $100 / 20$ & $99 / 21$ & $94 / 24$ & $83 / 23$ & 29,00 & 31,00 & 29,00 & 28,00 \\
\hline $07 / \mathrm{fev} / 00$ & 29,0 & 19,0 & $97 / 19$ & $94 / 20$ & $90 / 22$ & $87 / 21$ & 20,00 & 21,00 & 23,00 & 24,00 \\
\hline $08 / \mathrm{fev} / 00$ & 26,0 & 21,0 & $97 / 20$ & $96 / 21$ & $90 / 20$ & $87 / 21$ & 21,00 & 21,00 & 20,20 & 20,00 \\
\hline $09 / \mathrm{fev} / 00$ & 28,0 & 21,0 & $100 / 21$ & $85 / 22$ & $63 / 24$ & $67 / 24$ & 22,00 & 23,00 & 27,00 & 25,20 \\
\hline $10 / \mathrm{fev} / 00$ & 27,0 & 20,0 & $100 / 21$ & $86 / 21$ & $81 / 23$ & $90 / 21$ & 22,00 & 23,00 & 24,00 & 22,00 \\
\hline $11 / \mathrm{fev} / 00$ & 27,0 & 20,0 & $100 / 20$ & $98 / 21$ & $100 / 22$ & $99 / 21$ & 21,00 & 22,40 & 23,00 & 22,00 \\
\hline $12 / \mathrm{fev} / 00$ & 26,0 & 21,0 & $98 / 21$ & $94 / 20$ & $88 / 21$ & $85 / 20$ & 21,00 & 22,00 & 23,00 & 22,00 \\
\hline $13 /$ fev/00 & 29,0 & 22,0 & $100 / 22$ & $98 / 24$ & $97 / 22$ & $96 / 21$ & 24,00 & 24,00 & 23,00 & 23,60 \\
\hline $14 / \mathrm{fev} / 00$ & 26,0 & 20,0 & $100 / 21$ & $99 / 21$ & $94 / 22$ & $60 / 21$ & 22,00 & 23,00 & 23,00 & 24,60 \\
\hline $15 / \mathrm{fev} / 00$ & 29,0 & 22,0 & $100 / 22$ & $88 / 22$ & $54 / 24$ & $72 / 22$ & 23,00 & 24,00 & 26,00 & 25,00 \\
\hline $16 / \mathrm{fev} / 00$ & 28,0 & 20,0 & $100 / 20$ & $100 / 21$ & $71 / 24$ & $74 / 21$ & 21,00 & 23,00 & 26,00 & 24,00 \\
\hline $18 / \mathrm{fev} / 00$ & 28 & 20 & $98 / 18$ & $100 / 20$ & $77 / 20$ & $83 / 18$ & 20,00 & 20,60 & 22,00 & 20,00 \\
\hline $20 / \mathrm{fev} / 00$ & 28 & 21 & $100 / 19$ & $97 / 20$ & $86 / 20$ & $80 / 21$ & 20,00 & 23,00 & 23,00 & 22,00 \\
\hline $21 / \mathrm{fev} / 00$ & 25 & 20 & $98 / 17$ & $80 / 21$ & $60 / 20$ & $56 / 20$ & 19,00 & 22,00 & 23,00 & 22,00 \\
\hline $22 / \mathrm{fev} / 00$ & 30 & 22 & $100 / 20$ & $68 / 20$ & $64 / 21$ & $62 / 20$ & 22,00 & 21,00 & 22,00 & 26,00 \\
\hline $24 / \mathrm{fev} / 00$ & 27 & 21 & $100 / 20$ & $78 / 21$ & $55 / 22$ & $90 / 20$ & 22,00 & 23,00 & 25,00 & 22,00 \\
\hline $25 / \mathrm{fev} / 00$ & 26 & 19 & $100 / 20$ & $78 / 21$ & $55 / 22$ & $90 / 20$ & 21,00 & 23,00 & 26,00 & 24,00 \\
\hline $26 / \mathrm{fev} / 00$ & 27 & 21 & $97 / 20$ & $76 / 21$ & $72 / 20$ & $74 / 21$ & 22,00 & 22,00 & 23,00 & 23,00 \\
\hline $27 / \mathrm{fev} / 00$ & 29 & 19 & $98 / 20$ & $90 / 20$ & $85 / 21$ & $100 / 19$ & 22,00 & 24,00 & 25,00 & 20,00 \\
\hline $28 / \mathrm{fev} / 00$ & 27 & 20 & $100 / 20$ & $70 / 21$ & $64 / 22$ & $76 / 20$ & 22,00 & 23,00 & 24,00 & 22,00 \\
\hline $29 / \mathrm{fev} / 00$ & 29 & 20 & $98 / 20$ & $100 / 21$ & $70 / 20$ & $70 / 21$ & 22,00 & 22,00 & 22,00 & 21,00 \\
\hline $01 / \mathrm{mar} / 00$ & 27 & 20 & $20 / 100$ & $21 / 67$ & $22 / 79$ & $19 / 74$ & 21 & 23 & 23 & 18 \\
\hline $03 / \mathrm{mar} / 00$ & 29 & 21 & $18 / 100$ & $20 / 78$ & $20 / 70$ & $21 / 62$ & 20 & 22 & 24 & 23 \\
\hline $04 / \mathrm{mar} / 00$ & 29 & 20 & $20 / 100$ & $21 / 82$ & $22 / 78$ & $20 / 65$ & 20 & 23 & 24 & 22 \\
\hline $05 / \mathrm{mar} / 00$ & 30 & 21 & $19 / 96$ & $20 / 65$ & $22 / 50$ & $23 / 49$ & 21 & 22 & 25 & 25 \\
\hline $06 / \mathrm{mar} / 00$ & 30 & 22 & $19 / 97$ & $21 / 85$ & $23 / 72$ & $20 / 63$ & 22 & 23 & 25 & 26 \\
\hline $07 / \mathrm{mar} / 00$ & 29 & 20 & $19 / 97$ & $22 / 100$ & $22 / 98$ & $21 / 100$ & 22 & 22 & 21 & 20 \\
\hline $08 / \mathrm{mar} / 00$ & 27 & 20 & $19 / 96$ & $20 / 90$ & $21 / 88$ & $19 / 85$ & 21 & 22 & 21 & 19 \\
\hline $09 / \mathrm{mar} / 00$ & 28 & 22 & $18 / 97$ & $20 / 62$ & & & 20 & 23 & & \\
\hline $10 / \mathrm{mar} / 00$ & 27 & 20 & $18 / 84$ & $20 / 86$ & $19 / 69$ & $18 / 72$ & 20 & 21 & 20 & 21 \\
\hline $11 / \mathrm{mar} / 00$ & 28 & 20 & $19 / 100$ & $21 / 96$ & $20 / 100$ & $19 / 100$ & 21 & 23 & 21 & 20 \\
\hline $12 / \mathrm{mar} / 00$ & 27 & 20 & $19 / 97$ & $22 / 91$ & $24 / 86$ & $24 / 80$ & 20 & 25 & 26 & 25 \\
\hline $13 / \mathrm{mar} / 00$ & 27 & 21 & $17 / 98$ & $20 / 80$ & $21 / 76$ & $20 / 74$ & 19 & 21 & 21 & 20 \\
\hline $14 / \mathrm{mar} / 00$ & 26 & 21 & $17 / 96$ & $19 / 74$ & $17 / 62$ & $16 / 70$ & 19 & 21 & 22 & 21 \\
\hline $15 / \mathrm{mar} / 00$ & 27 & 21 & 19/99 & $20 / 96$ & $23 / 85$ & $21 / 79$ & 20 & 22 & & \\
\hline $17 / \mathrm{mar} / 00$ & 28 & 20 & $20 / 100$ & $21 / 96$ & $20 / 100$ & $21 / 82$ & 21 & 23 & 22 & 22 \\
\hline $18 / \mathrm{mar} / 00$ & 28 & 21 & $20 / 98$ & $22 / 97$ & $21 / 100$ & $20 / 90$ & 21 & 24 & 23 & 21 \\
\hline $19 / \mathrm{mar} / 00$ & 27 & 19 & $20 / 91$ & $20 / 97$ & $20 / 97$ & $19 / 91$ & 21 & 21 & 22 & 20 \\
\hline $20 / \mathrm{mar} / 00$ & 26 & 20 & $21 / 100$ & $21 / 97$ & $22 / 98$ & $20 / 100$ & 21 & 23 & 23 & 20 \\
\hline $21 / \mathrm{mar} / 00$ & 26 & 18 & $20 / 100$ & $21 / 87$ & $19 / 94$ & $19 / 99$ & 20 & 21 & 20 & 20 \\
\hline $22 / \mathrm{mar} / 00$ & 26 & 19 & $20 / 100$ & $19 / 96$ & $18 / 76$ & $19 / 100$ & 20 & 20 & 20 & 19 \\
\hline $24 / \mathrm{mar} / 00$ & 29 & 21 & $20 / 97$ & $22 / 75$ & $22 / 74$ & $20 / 71$ & 20 & 27 & 24 & 23 \\
\hline $29 / \mathrm{mar} / 00$ & 27 & 19 & $20 / 100$ & $20 / 96$ & $19 / 87$ & $20 / 90$ & 21 & 20 & 20 & 20 \\
\hline $31 / \mathrm{mar} / 00$ & 28 & 20 & $20 / 100$ & $20 / 96$ & $21 / 88$ & $19 / 87$ & 20 & 21 & 21 & 21 \\
\hline
\end{tabular}


Fazenda Santa Terezinha Medidas de Temperatura e Umidade Relativa

Tie-stall

\begin{tabular}{|c|c|c|c|c|c|c|c|c|c|c|}
\hline Dias & $\begin{array}{c}\text { Temp. } \\
\left.\text { máx ( }{ }^{\circ} \mathrm{C}\right)\end{array}$ & $\begin{array}{l}\text { Temp. } \\
\text { Mín }\left({ }^{\circ} \mathrm{C}\right)\end{array}$ & $\begin{array}{c}\text { UR/Temp } 7 \\
\text { h }\left(\% /{ }^{\circ} \mathrm{C}\right)\end{array}$ & $\begin{array}{c}\text { UR/Temp } \\
11 \text { h }\left(\%{ }^{\circ} \mathrm{C}\right)\end{array}$ & $\begin{array}{c}\text { UR/Temp } \\
13 \mathrm{~h}\left(\%{ }^{\circ} \mathrm{C}\right)\end{array}$ & $\begin{array}{c}\text { UR/Temp 17 } \\
\text { h }\left(\% /{ }^{\circ} \mathbf{C}\right)\end{array}$ & $\begin{array}{c}\text { TGN } 7 \mathrm{~h} \\
\left({ }^{\circ} \mathrm{C}\right)\end{array}$ & $\begin{array}{c}\text { TGN } 11 \mathrm{~h} \\
\left({ }^{\circ} \mathrm{C}\right)\end{array}$ & $\begin{array}{c}\text { TGN } 13 \mathrm{~h} \\
\left({ }^{\circ} \mathrm{C}\right)\end{array}$ & $\begin{array}{c}\text { TGN } 17 \mathrm{~h} \\
\left({ }^{\circ} \mathrm{C}\right)\end{array}$ \\
\hline $17 / \mathrm{jan} / 00$ & 38,0 & 26,0 & $75 / 29$ & & $66 / 29$ & \begin{tabular}{|l|}
$83 / 25$ \\
\end{tabular} & 24,0 & & & 31,0 \\
\hline $18 / \mathrm{jan} / 00$ & 30,0 & 22,0 & $66 / 22$ & & & $60 / 29$ & 24,0 & & & 30,0 \\
\hline $19 / \mathrm{jan} / 00$ & 29,0 & 23,0 & $96 / 23$ & $71 / 28$ & $87 / 24$ & $91 / 23,7$ & 23,8 & 24,0 & 24,0 & 23,8 \\
\hline $21 / \mathrm{jan} / 00$ & 29,0 & 20,0 & $90 / 21$ & $86 / 23$ & $65 / 24$ & $65 / 24$ & 21,0 & 20,0 & 21,0 & 23,0 \\
\hline $22 / \mathrm{jan} / 00$ & 33,0 & 19,0 & $96 / 20$ & $68 / 19$ & $51 / 20$ & $52 / 20$ & 21,0 & 22,0 & 20,0 & 20,0 \\
\hline $23 / \mathrm{jan} / 00$ & 32,0 & 19,0 & $90 / 19$ & $58 / 19$ & $51 / 20$ & $50 / 20$ & 20,0 & 19,0 & 20,0 & 21,0 \\
\hline $24 / \mathrm{jan} / 00$ & 31,0 & 19,0 & $94 / 20$ & $71 / 22$ & $62 / 27$ & $70 / 25$ & 20,0 & 22,0 & 26,0 & 26,0 \\
\hline $26 / \mathrm{jan} / 00$ & 30,0 & 21,0 & $99 / 21$ & $78 / 23$ & $95 / 22$ & $93 / 21$ & 21,4 & 24,0 & 23,0 & 23,2 \\
\hline $27 / \mathrm{jan} / 00$ & 32,0 & 21,0 & $99 / 21$ & $77 / 23$ & $96 / 22$ & $94 / 21$ & 21,4 & 24,3 & 23,1 & 23,2 \\
\hline $28 / \mathrm{jan} / 00$ & 32,0 & 19,0 & $91 / 19$ & $58 / 22$ & $64 / 22$ & $60 / 22$ & 19,0 & 22,4 & 22,0 & 22,4 \\
\hline $29 / \mathrm{jan} / 00$ & 33,0 & 22,0 & $99 / 18$ & $70 / 22$ & $50 / 28$ & $64 / 24$ & 19,0 & 22,0 & 28,0 & 25,0 \\
\hline $30 / \mathrm{jan} / 00$ & 24,0 & 19,0 & $98 / 19$ & $68 / 22$ & $69 / 23$ & $70 / 23$ & 19,0 & 22,8 & 22,8 & 22,6 \\
\hline $31 / \mathrm{jan} / 00$ & 3,0 & 19,0 & $94 / 20$ & $78 / 23$ & $68 / 24$ & $94 / 20$ & 20,6 & 23,0 & 23,6 & 21,0 \\
\hline $01 / \mathrm{fev} / 00$ & 30 & 18 & $80 / 20$ & $71 / 21$ & $76 / 18$ & & 21,0 & 22,0 & 23,0 & 21,0 \\
\hline $02 / \mathrm{fev} / 00$ & 29 & 20 & $99 / 21$ & $74 / 25$ & $58 / 26$ & $68 / 23$ & 22,0 & 25,4 & 27,0 & 23,4 \\
\hline $03 / \mathrm{fev} / 00$ & 29 & 20 & $100 / 21$ & $74 / 25$ & $58 / 26$ & $68 / 23$ & 22,0 & 25,2 & 27,2 & 22,3 \\
\hline $04 / \mathrm{fev} / 00$ & 32 & 19 & $100 / 21$ & $85 / 23$ & $55 / 26$ & $53 / 29$ & 21,0 & 23,6 & 27,0 & 29,0 \\
\hline $05 / \mathrm{fev} / 00$ & 33 & 21 & $100 / 21$ & $72 / 24$ & $60 / 23$ & $68 / 26$ & 22,0 & 25,6 & 25,0 & 24,0 \\
\hline $06 / \mathrm{fev} / 00$ & 30 & 21 & $100 / 20$ & $85 / 22$ & $86 / 24$ & $78 / 23$ & 21,0 & 23,0 & 25,0 & 25,0 \\
\hline $07 / \mathrm{fev} / 00$ & 29 & 20 & $98 / 20$ & $96 / 21$ & $92 / 22$ & $89 / 22$ & 21,0 & 22,0 & 23,0 & 25,0 \\
\hline $08 / \mathrm{fev} / 00$ & 25 & 21 & $91 / 20$ & $90 / 21$ & $90 / 22$ & $91 / 20$ & 21,0 & 21,0 & 20,0 & 20,0 \\
\hline $09 / \mathrm{fev} / 00$ & 29 & 21 & $100 / 20$ & $80 / 21$ & $60 / 26$ & $68 / 24$ & 21,0 & 22,0 & 27,2 & 26,0 \\
\hline $10 / \mathrm{fev} / 00$ & 29 & 21 & $100 / 20$ & $85 / 23$ & $73 / 25$ & $84 / 22$ & 21,0 & 24,0 & 25,0 & 24,0 \\
\hline $11 / \mathrm{fev} / 00$ & 29 & 20 & $100 / 20$ & $99 / 21$ & $100 / 22$ & $98 / 20$ & 22,0 & 23,0 & 24,0 & 23,0 \\
\hline $12 / \mathrm{fev} / 00$ & 25 & 20 & $100 / 20$ & $96 / 21$ & $90 / 20$ & $88 / 21$ & 21,0 & 21,0 & 23,0 & 22,0 \\
\hline $13 / \mathrm{fev} / 00$ & 29 & 21 & $100 / 20$ & $98 / 21$ & $90 / 20$ & $89 / 20$ & 22,0 & 21,0 & 22,0 & 22,0 \\
\hline $14 /$ fev/00 & 27 & 19 & $98 / 20$ & $96 / 21$ & $92 / 22$ & $89 / 21$ & 21,0 & 23,0 & 24,0 & 22,0 \\
\hline $15 / \mathrm{fev} / 00$ & 30 & 22 & $89 / 21$ & $80 / 22$ & $52 / 25$ & $76 / 21$ & 23,0 & 23,0 & 27,0 & 22,0 \\
\hline $16 / \mathrm{fev} / 00$ & 28 & 21 & 98/19 & $100 / 21$ & $68 / 23$ & $70 / 24$ & 20,0 & 23,0 & 26,0 & 24,0 \\
\hline $18 / \mathrm{fev} / 00$ & 27 & 20 & $100 / 20$ & $79 / 20$ & $74 / 20$ & $72 / 20$ & 21,0 & 21,0 & 21,0 & 20,0 \\
\hline $20 / \mathrm{fev} / 00$ & 27 & 21 & $80 / 20$ & $74 / 20$ & $52 / 22$ & $60 / 21$ & 22,0 & 21,0 & 24,0 & 23,0 \\
\hline $21 /$ fev/00 & 30 & 22 & $100 / 18$ & $71 / 20$ & $54 / 21$ & $50 / 22$ & 20,0 & 22,0 & 23,0 & 25,0 \\
\hline $22 / \mathrm{fev} / 00$ & 29 & 23 & $100 / 19$ & $74 / 23$ & $56 / 24$ & $60 / 25$ & 22,0 & 25,0 & 25,0 & 27,0 \\
\hline $24 / \mathrm{fev} / 00$ & 30 & 22 & $98 / 21$ & $87 / 24$ & $81 / 25$ & $86 / 20$ & 22,0 & 25,0 & 26,0 & 21,0 \\
\hline $25 / \mathrm{fev} / 00$ & 29 & 21 & $100 / 19$ & $78 / 22$ & $70 / 25$ & $79 / 24$ & 21,0 & 24,0 & 27,0 & 25,0 \\
\hline $26 / \mathrm{fev} / 00$ & 29 & 21 & $96 / 20$ & $80 / 23$ & $80 / 23$ & $79 / 22$ & 22,0 & 25,0 & 24,0 & 24,0 \\
\hline $27 / \mathrm{fev} / 00$ & 30 & 21 & $100 / 21$ & $68 / 25$ & $50 / 27$ & $100 / 20$ & 22,0 & 24,0 & 29,0 & 22,0 \\
\hline $28 / \mathrm{fev} / 00$ & 29 & 20 & $99 / 20$ & $68 / 27$ & $50 / 29$ & $82 / 20$ & 21,0 & 29,0 & 32,0 & 23,0 \\
\hline $29 / \mathrm{fev} / 00$ & 29 & 20 & $100 / 20$ & $75 / 23$ & $72 / 24$ & $69 / 23$ & 21,0 & 25,0 & 26,0 & 23,0 \\
\hline $01 / \mathrm{mar} / 00$ & 30 & 22 & $19 / 90$ & $23 / 65$ & $21 / 70$ & $20 / 67$ & 21,0 & 23,0 & 22,0 & 22,0 \\
\hline $03 / \mathrm{mar} / 00$ & 32 & 21 & $20 / 90$ & $21 / 79$ & $23 / 60$ & $24 / 55$ & 20,0 & 23,0 & 26,0 & 27,0 \\
\hline $04 / \mathrm{mar} / 00$ & 30 & 21 & $20 / 97$ & $22 / 78$ & $24 / 72$ & $22 / 60$ & 21,0 & 23,0 & 24,0 & 25,0 \\
\hline $05 / \mathrm{mar} / 00$ & 32 & 22 & $20 / 90$ & $22 / 83$ & $25 / 48$ & $24 / 45$ & 22,0 & 24,0 & 27,0 & 27,0 \\
\hline $06 / \mathrm{mar} / 00$ & 31 & 23 & $20 / 90$ & $22 / 86$ & $24 / 78$ & $26 / 70$ & 22,0 & 23,0 & 25,0 & 27,0 \\
\hline $07 / \mathrm{mar} / 00$ & 32 & 22 & $20 / 100$ & $20 / 100$ & $22 / 96$ & $20 / 100$ & 22,0 & 21,0 & 22,0 & 21,0 \\
\hline $08 / \mathrm{mar} / 00$ & 29 & 20 & $20 / 89$ & $21 / 92$ & $20 / 87$ & $19 / 79$ & 20,0 & 22,0 & 21,0 & 20,0 \\
\hline $09 / \mathrm{mar} / 00$ & 30 & 22 & $19 / 96$ & $20 / 62$ & & & 20,0 & 24,0 & & \\
\hline $10 / \mathrm{mar} / 00$ & 29 & 21 & $19 / 78$ & $20 / 75$ & $21 / 64$ & $19 / 75$ & 21,0 & 20,0 & 23,0 & 20,0 \\
\hline $11 / \mathrm{mar} / 00$ & 30 & 21 & $20 / 100$ & $22 / 90$ & $20 / 96$ & $20 / 97$ & 20,0 & 23,0 & 22,0 & 21,0 \\
\hline $12 / \mathrm{mar} / 00$ & 29 & 21 & $21 / 91$ & $23 / 86$ & $25 / 80$ & $25 / 79$ & 22,0 & 24,0 & 27,0 & 26,0 \\
\hline $13 / \mathrm{mar} / 00$ & 30 & 21 & $19 / 87$ & $20 / 76$ & $21 / 74$ & $20 / 69$ & 20,0 & 22,0 & 22,0 & 21,0 \\
\hline $14 / \mathrm{mar} / 00$ & 27 & 20 & $17 / 93$ & $20 / 72$ & $22 / 60$ & $21 / 64$ & 20,0 & 23,0 & 26,0 & 24,0 \\
\hline $15 / \mathrm{mar} / 00$ & 29 & 21 & $20 / 90$ & $20 / 84$ & $22 / 78$ & $20 / 74$ & 22,0 & 22,0 & 24,0 & 23,0 \\
\hline $17 / \mathrm{mar} / 00$ & 29 & 21 & $19 / 100$ & $21 / 97$ & $23 / 93$ & $20 / 95$ & 21,0 & 23,0 & 24,0 & 21,0 \\
\hline $18 / \mathrm{mar} / 00$ & 29 & 21 & $20 / 100$ & $23 / 74$ & $22 / 90$ & $22 / 90$ & 20,0 & 21,0 & 25,0 & 23,0 \\
\hline $19 / \mathrm{mar} / 00$ & 29 & 20 & $19 / 92$ & $20 / 98$ & $20 / 96$ & $19 / 90$ & 21,0 & 20,0 & 21,0 & 21,0 \\
\hline $20 / \mathrm{mar} / 00$ & 26 & 21 & $21 / 100$ & $20 / 94$ & $21 / 87$ & $18 / 98$ & 22,0 & 20,0 & 23,0 & 20,0 \\
\hline $21 / \mathrm{mar} / 00$ & 27 & 20 & $19 / 100$ & $20 / 86$ & $20 / 96$ & $20 / 100$ & 20,0 & 21,0 & 21,0 & 20,0 \\
\hline $22 / \mathrm{mar} / 00$ & 27 & 20 & $19 / 100$ & $21 / 96$ & $21 / 67$ & $19 / 98$ & 20,0 & 21,0 & 22,0 & 20,0 \\
\hline $24 / \mathrm{mar} / 00$ & 29 & 20 & $20 / 100$ & $22 / 78$ & $20 / 71$ & $20 / 68$ & 21,0 & 24,0 & 23,0 & 22,0 \\
\hline $29 / \mathrm{mar} / 00$ & 28 & 19 & $19 / 100$ & $20 / 97$ & $19 / 87$ & $19 / 86$ & 21,0 & 20,0 & 19,0 & 20,0 \\
\hline $31 / \mathrm{mar} / 00$ & 28 & 19 & $19 / 100$ & $21 / 97$ & $20 / 84$ & $20 / 76$ & 20,0 & 20,0 & 21,0 & 20,0 \\
\hline
\end{tabular}




\begin{tabular}{|c|c|c|c|c|c|c|c|c|}
\hline Dias & $\begin{array}{c}\text { Temp. } \\
\text { máx }\left({ }^{\circ} \mathrm{C}\right)\end{array}$ & $\begin{array}{c}\text { Temp. } \\
\left.\text { Mín ( }{ }^{\circ} \mathrm{C}\right)\end{array}$ & $\begin{array}{c}\text { UR/Temp } 7 \\
\text { h }\left(\% /{ }^{\circ} \mathrm{C}\right) \\
\end{array}$ & $\begin{array}{c}\text { UR/Temp } \\
13 \mathrm{~h}\left(\% /{ }^{\circ} \mathrm{C}\right)\end{array}$ & $\begin{array}{c}\text { UR/Temp } 17 \\
\text { h }\left(\% /{ }^{\circ} \mathrm{C}\right) \\
\end{array}$ & $\begin{array}{c}\text { TGN } 7 \mathrm{~h} \\
\left({ }^{\circ} \mathrm{C}\right)\end{array}$ & $\begin{array}{c}\text { TGN } 13 \mathrm{~h} \\
\left({ }^{\circ} \mathrm{C}\right)\end{array}$ & $\begin{array}{c}\text { TGN } 17 \mathrm{~h} \\
\left({ }^{\circ} \mathrm{C}\right)\end{array}$ \\
\hline $20 /$ fev/00 & & & & $54 / 26$ & $61 / 26$ & & 27 & 26 \\
\hline $21 /$ fev/00 & 28 & 18 & $100 / 20$ & $50 / 29$ & $44 / 30$ & 20 & 31 & 31 \\
\hline $22 / \mathrm{fev} / 00$ & 32 & 18 & $92 / 19$ & $47 / 31$ & $56 / 29$ & 20 & 33 & 30 \\
\hline $23 / \mathrm{fev} / 00$ & 33 & 22 & $95 / 20$ & $46 / 32$ & $58 / 27$ & 21 & 32 & 28 \\
\hline $24 / \mathrm{fev} / 00$ & 34 & 18 & $97 / 19$ & $48 / 31$ & $86 / 23$ & 20 & 32 & 23 \\
\hline $25 / \mathrm{fev} / 00$ & 34 & 19 & $100 / 19$ & $66 / 28$ & $66 / 27$ & 20 & 29 & 28 \\
\hline $26 / \mathrm{fev} / 00$ & 30 & 18 & $99 / 21$ & $51 / 31$ & $62 / 28$ & 21 & 32 & 29 \\
\hline $27 / \mathrm{fev} / 00$ & 32 & 18 & $93 / 22$ & $45 / 34$ & $89 / 21$ & 22 & 34 & 22 \\
\hline $28 / \mathrm{fev} / 00$ & 34 & 19 & $97 / 19$ & $51 / 30$ & $83 / 23$ & 20 & 31 & 24 \\
\hline $29 / \mathrm{fev} / 00$ & 23 & 19 & $96 / 21$ & $50 / 32$ & $86 / 23$ & 20 & 33 & 24 \\
\hline $01 / \mathrm{mar} / 00$ & 32 & 20 & $20 / 92$ & $29 / 51$ & $26 / 71$ & 20 & 31 & 27 \\
\hline $02 / \mathrm{mar} / 00$ & 32 & 18 & $21 / 92$ & $30 / 43$ & $25 / 68$ & 21 & 32 & 27 \\
\hline $03 / \mathrm{mar} / 00$ & 34 & 18 & $21 / 91$ & $31 / 42$ & $25 / 65$ & 22 & 32 & 28 \\
\hline $04 / \mathrm{mar} / 00$ & 33 & 18 & $21 / 89$ & $31 / 48$ & $26 / 69$ & 22 & 33 & 27 \\
\hline $05 / \mathrm{mar} / 00$ & 35 & 22 & $22 / 92$ & $33 / 44$ & $26 / 71$ & 22 & 34 & 27 \\
\hline $06 / \mathrm{mar} / 00$ & 35 & 22 & $20 / 100$ & $32 / 47$ & $30 / 58$ & 21 & 33 & 29 \\
\hline $07 / \mathrm{mar} / 00$ & & & & $21 / 100$ & $21 / 95$ & & 22 & 20 \\
\hline $08 / \mathrm{mar} / 00$ & 34 & 21 & $20 / 97$ & $22 / 68$ & $19 / 78$ & 20 & 23 & 19 \\
\hline $09 / \mathrm{mar} / 00$ & 28 & 18 & $17 / 94$ & $27 / 57$ & $20 / 70$ & 17 & 27 & 21 \\
\hline $10 / \mathrm{mar} / 00$ & 28 & 18 & $18 / 90$ & $27 / 58$ & $22 / 68$ & 18 & 29 & 22 \\
\hline $11 / \mathrm{mar} / 00$ & 30 & 18 & $19 / 95$ & $22 / 92$ & $20 / 84$ & 20 & 23 & 21 \\
\hline $12 / \mathrm{mar} / 00$ & 26 & 20 & $19 / 96$ & $23 / 66$ & $21 / 73$ & 19 & 25 & 20 \\
\hline $13 / \mathrm{mar} / 00$ & 24 & 17 & $16 / 99$ & $24 / 57$ & $21 / 72$ & 17 & 26 & 22 \\
\hline $14 / \mathrm{mar} / 00$ & 28 & 19 & $18 / 94$ & $28 / 53$ & & 19 & 29 & 23 \\
\hline $15 / \mathrm{mar} / 00$ & 29 & 19 & & $75 / 24$ & $68 / 26$ & & 25 & 25 \\
\hline $16 / \mathrm{mar} / 00$ & 28 & 21 & $92 / 21$ & $62 / 29$ & $81 / 24$ & 22 & 30 & 25 \\
\hline $17 / \mathrm{mar} / 00$ & 33 & 22 & $97 / 22$ & $61 / 28$ & $71 / 26$ & 22 & 28 & 27 \\
\hline $18 / \mathrm{mar} / 00$ & 31 & 21 & $93 / 22$ & $80 / 26$ & $79 / 25$ & 23 & 26 & 25 \\
\hline $19 / \mathrm{mar} / 00$ & 30 & 20 & $100 / 20$ & $78 / 23$ & $83 / 20$ & 22 & 25 & 23 \\
\hline $20 / \mathrm{mar} / 00$ & 24 & 19 & $94 / 19$ & $90 / 22$ & $97 / 21$ & 20 & 23 & 22 \\
\hline $21 / \mathrm{mar} / 00$ & 24 & 18 & $92 / 21$ & $71 / 26$ & $96 / 21$ & 21 & 28 & 22 \\
\hline
\end{tabular}




\section{Anexo II}

Modelos de planilhas de campo para uso no programa Custo Leite 
Nome da Empresa Rural:

Mês e Ano do controle:

\section{Despesas}

\section{1) Despesas com Mão-de-Obra (R\$)}

\begin{tabular}{|l|l|l|}
\hline Mão-de-Obra Contratada & Assistência Zootécnica & \\
\hline Encargos Sociais & Consultorias Ocasionais & \\
\hline Assistência Agronômica & Mão-de-Obra Eventual & \\
\hline Assistência Contábil & Mão-de-Obra Familiar & \\
\hline Assistência Veterinária & Outras & \\
\hline
\end{tabular}

\section{1) Discriminação da Mão-de-Obra (Quantidade)}

\begin{tabular}{|l|l|l|}
\hline Arraçoamento & Secretaria & \\
\hline Encarregado & Serviços Gerais & \\
\hline Limpeza & Tratorista & \\
\hline Ordenhador & Outros & \\
\hline
\end{tabular}

\section{2) Despesas com Alimentação ( $R$ \$)}

\begin{tabular}{|l|l|l|}
\hline Aditivos & Ração Comercial & \\
\hline Cana & Sal Comum & \\
\hline Capineira & Silagem & \\
\hline Farelo de Soja & Suplemento Mineral & \\
\hline Feno & Leite & \\
\hline Outros Grãos ou Farelos & Milho & \\
\hline Pastagens & Núcleo & \\
\hline Premix & Outros & \\
\hline
\end{tabular}

\section{3) Despesas com Sanidade (R\$)}

\begin{tabular}{|l|l|l|}
\hline Água Oxigenada & lodo & \\
\hline Agulhas & Mata Bicheiras & \\
\hline Álcool & Seringas & \\
\hline Anestésicos & Sulfato de Cobre & \\
\hline Antibióticos & Tintura de lodo & \\
\hline Anti-inflamatórios & Vacina Aftosa & \\
\hline Anti-mastísticos & Vacina Brucelose & \\
\hline Anti-térmicos & Vacina Carbúnculo & \\
\hline Complemento Vitamínico & Vacina Diarréia Viral & \\
\hline Cálcio e Fósforo & Vacina Leptospirose & \\
\hline Drench & Vacina Paratifo & \\
\hline Exame Brucelose & Vacina Raiva & \\
\hline Exame Tuberculose & Vacina Rinotraqueíte Inf. & \\
\hline Formol & Vermífugo & \\
\hline Hormônios & Outros & \\
\hline
\end{tabular}




\section{4) Despesas com Reprodução ( $R$ \$)}

\begin{tabular}{|l|l|}
\hline Aplicador & \\
\hline Bainha & \\
\hline Luvas & \\
\hline Nitrogênio & \\
\hline Pipeta & \\
\hline Sêmem & \\
\hline Outros & \\
\hline
\end{tabular}

\section{5) Despesas com Ordenha $(R \$)$}

\begin{tabular}{|l|l|l|l|}
\hline Óleo p/ bomba de vácuo & Camisa de Filtro & \\
\hline Papel & & Detergente Ácido & \\
\hline Peças para reposição & Detergente Alcalino & \\
\hline Pós-dipping & Escovas & \\
\hline Pré-dipping & Hipoclorito & \\
\hline Reagente CMT & Outros & \\
\hline Sabão em Pó & \multicolumn{2}{|l}{} \\
\hline
\end{tabular}

\section{6) Despesas com Impostos (R\$)}

\begin{tabular}{|l|l|}
\hline ITR & \\
\hline IPVA & \\
\hline Outros & \\
\hline
\end{tabular}

\section{7) Despesas Diversas ( $R \$)$}

\begin{tabular}{|c|c|}
\hline Brincos (p/identificação) & Impostos (PIS, COFINS, ...) \\
\hline Bancos p/ Free Stall & Lubrificantes \\
\hline Combustível & Materiais para Limpeza \\
\hline Contribuição Rural & Materiais para Escritório \\
\hline Disquetes & Reparo de Benfeitorias \\
\hline Encargos Financeiros (juros) & Reparo de Equipamentos \\
\hline Horas de Trator & Reparo de Máquinas \\
\hline Energia & Rep. e Manut. de Veículos \\
\hline Fita & Taxas \\
\hline Formulário & Cartucho para Empressora \\
\hline Frete & Transporte de Leite \\
\hline
\end{tabular}




\section{Produção}

1) Quantidade Total de (em Kg)

\begin{tabular}{|l|l|l|l|}
\hline Leite B vendido & Leite consumido na sede & \\
\hline Leite C vendido & Leite descartado & \\
\hline Leite Extra Cota vendido & $\begin{array}{l}\text { Número Total de Matrizes do } \\
\text { Rebanho }\end{array}$ & \\
\hline Leite Indústria vendido & $\begin{array}{l}\text { Número Médio de Matrizes em } \\
\text { Lactação }\end{array}$ & $\begin{array}{l}\text { Área do Sistema de Produção } \\
\text { (hectare) }\end{array}$ & \\
\hline Leite destinado a bezerros & \multicolumn{2}{|l}{} \\
\hline Leite para funcionários & &
\end{tabular}

\section{Receitas}

\section{1) Receitas ( $\mathbf{R} \$$}

\begin{tabular}{|l|l|l|}
\hline Venda de Gordura & Venda de Matrizes & \\
\hline Venda de Bezerras & Venda de Outros Animais & \\
\hline Venda de Novilhas & Venda de Esterco & \\
\hline Venda de Garrotes & Outras Receitas & \\
\hline Venda de Reprodutores & &
\end{tabular}

\section{Cadastro de preços}

\section{1) Cadastro de Preços (R\$ / Kg)}

\begin{tabular}{|l|l|l|l|}
\hline Preço do Leite B & & Preço do Leite Extra Cota & \\
\hline Preço do Leite C & & Preço do Leite Indústria & \\
\hline
\end{tabular}

\section{Remuneração}

\section{1) Remuneração (R\$)}

\begin{tabular}{|l|l|}
\hline Empresário & \\
\hline $\begin{array}{l}\text { Terra (valor mensal do hectare } \\
\text { arrendado) }\end{array}$ & \\
\hline Juros ao mês (\%) & \\
\hline
\end{tabular}


Ficha para Controle de Inventário de Patrimônio

Nome da Empresa Rural:

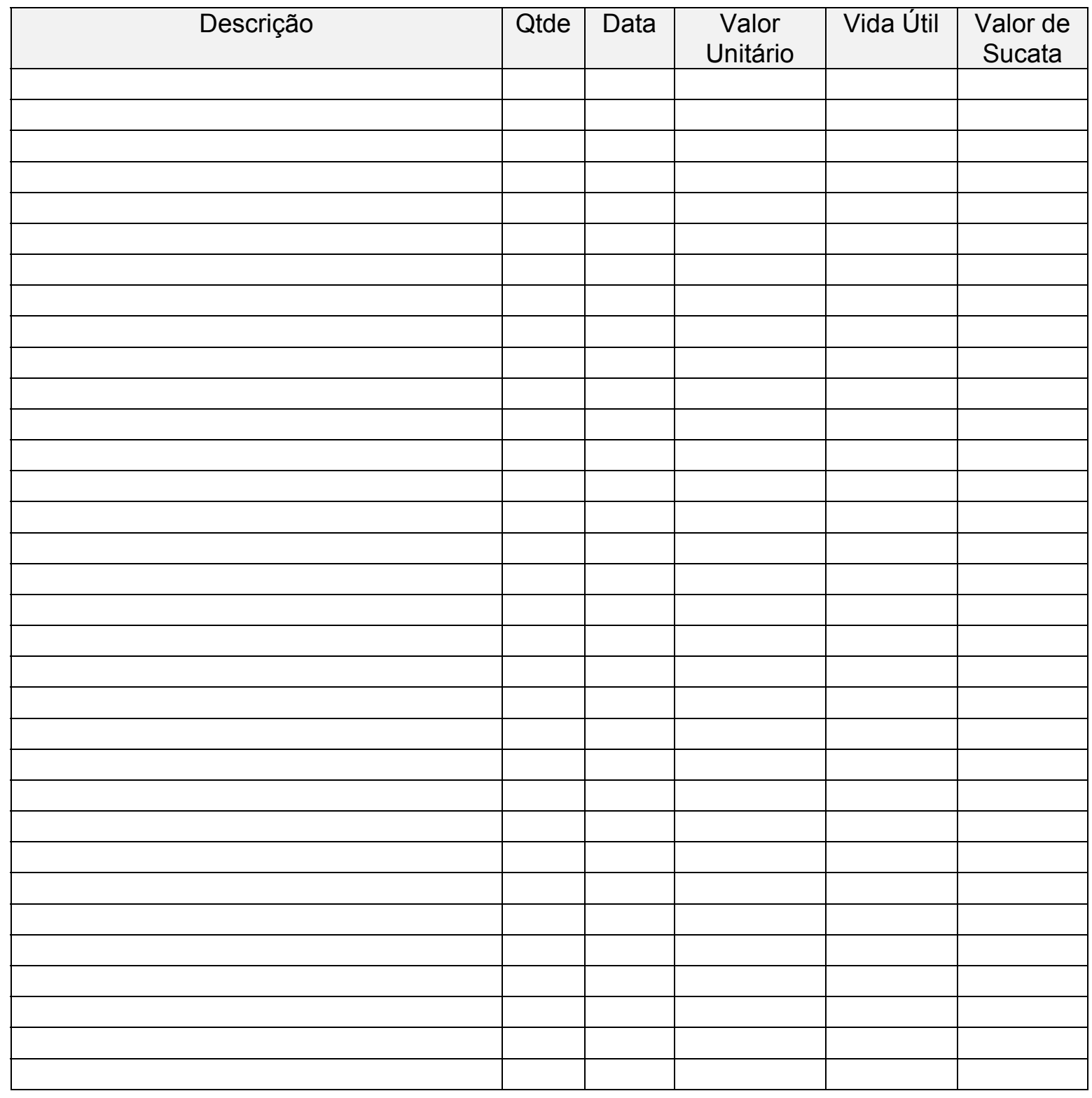

Soluções para Agroinformática

SIN- Soluções Informatizadas para Negócios Ltda

CRITT - Centro Regional de Inovação e Transferência de Tecnologia Campus da UFJF Caixa Postal 20.010 CEP: 36016-970 Tel: (032) 217-9515 Fax: (032) 229-3480 Juiz de Fora Minas Gerais Brasil www.artnet.com.br/ sin E-mails: sin.suporte@artnet.com.br -- sin@artnet.com.br 